\title{
ECONOMIC IMPACT OF USING NONMETALIC MATERIALS IN LOW TO INTERMEDIATE TEMPERATURE GEOTHERMAL WELL CONSTRUCTION
} VOLUME II

December 1979

\section{MASTER}

\author{
Prepared by the \\ NATIONAL WATER WELL ASSOCIATION \\ WORTHINGTON, OHIO \\ For the \\ PROCESS SCIENCES DIVISION
}

DEPARTMENT OF ENERGY AND ENVIRONMENT

BROOKHAVEN NATIONAL LABORATORY UPTON, NEW YORK 11973 


\section{DISCLAIMER}

This report was prepared as an account of work sponsored by an agency of the United States Government. Neither the United States Government nor any agency Thereof, nor any of their employees, makes any warranty, express or implied, or assumes any legal liability or responsibility for the accuracy, completeness, or usefulness of any information, apparatus, product, or process disclosed, or represents that its use would not infringe privately owned rights. Reference herein to any specific commercial product, process, or service by trade name, trademark, manufacturer, or otherwise does not necessarily constitute or imply its endorsement, recommendation, or favoring by the United States Government or any agency thereof. The views and opinions of authors expressed herein do not necessarily state or reflect those of the United States Government or any agency thereof. 


\section{DISCLAIMER}

Portions of this document may be illegible in electronic image products. Images are produced from the best available original document. 


\title{
master
}

BNL 51224 Vol. II

UC-66d

(Geothermal Energy-Utilization

Technology - TID-4500)

\section{ECONOMIC IMPACT OF USING NONMETALLIC MATERIALS \\ IN LOW TO INTERMEDIATE TEMPERATURE GEOTHERMAL WELL CONSTRUCTION}

\author{
VOLUME II
}

December 1979

Prepared by the

NATIONAL WATER WELL ASSOCIATION

Worthington, Ohio

Under BNL Contract No. 485874-S

Contributors:

Tylor E. Gass

Wayne H. Purdin

Dana M. Armitage

For the

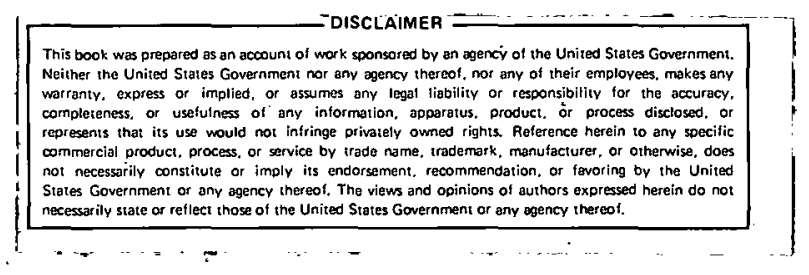

PROCESS SCIENCES DIVISION

\section{DEPARTMENT OF ENERGY AND ENVIRONMENT \\ BROOKHAVEN NATIONAL LABORATORY \\ ASSOCIATED UNIVERSITIES, INC.}

UNDER CONTRACT NO. DE-AC02-76CH00016 WITH THE

UNITED STATES DEPARTMENT OF ENERGY 


\section{DISCLAIMLK}

This book was prepared as an account of work sponsored by an agency of the United States Government. Neither the United States Government nor any agency thereof, nor any of their emplnyees, makes any warranty, express or implied, or assumes any legal liability or responsibility for the accuracy, completeness, or usefulness of any

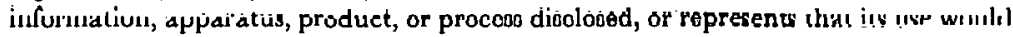
not infringe privately owned rights. Reference herein to any specific commercial product, process, or service by trade name, trademark, manufacturer, or otherwise, does not necessarily constitute or imply its endorsement, recommendation, or favoring by the United Stales Government or any agency thereof. The views and opinions of authors expressed, herein do not necessarily state or reflect those of the United States Guvermuent un ally agency thereof.

Printed in the United States of America Available from

National Technical Information Service

U.S. Department of Commerce

5285 Port Royal Road

Springfield, VA 22161

Price: Printed Copy $\$ 6.50 ;$ Microfiche $\$ 3.00$ 


\section{TABLE OF CONTENTS}

Appendix A - Applications of Low-Temperature Geothermal Energy.. 1

Industrial Processes................................. 4

Agricultural and Related Processes.................... 8

District Heating and Cooling ........................ 9

Miscellaneous Applications......................... 14

Appendix B - Hydrogeologic Factors Affecting the Design and

Construction of Low-Temperature Geothermal Wells............. 15

Water Qual ity.................................... 16

Withdrawal Rate................................... 29

Water Depth....................................... 32

Water Temperature.................................... 33

Basic Well Designs................................... 37

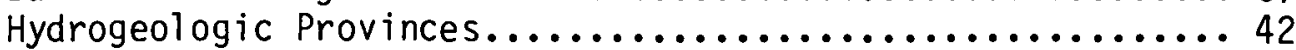

Appendix C - Properties of Metallic and Nonmetallic Materials... 47

Specific Gravity.............................. 47

Mechanical Strength Properties....................... 49

Resistance to Physical and Biological Attack.............. 63

Thermal Properties of Nonmetallics.................... 63

Fl uid Flow Characteristics........................... 65

Corrosion Resistance............................... 66

Scaling Resistance................................ 74

Weathering Resistance of Nonmetallics................. 75

Hydrolysis Resistance of Nonmetallics.................. 76

Appendix D - Special Considerations in the Design and Construction

of Low-Temperature Geothermal Wells Using Nonmetall ic

Materials........................................... 77

Dritling Methods.................................. 77

Joining Methods................................ 84

Methods of Casing and Screen Installation............... 92

Well Cementing..................................... 97

Wel1 1 Devel opment......................................101

Notes on Units.........................................108

References...........................................109 


\section{APPENDIX A. APPLICATIONS OF LOW-TEMPERATURE GEOTHERMAL ENERGY}

Low-temperature geothermal energy shows great promise for widespread application in the United States. With a temperature range of $4^{\circ}$ to $150^{\circ} \mathrm{C}\left(39^{\circ}\right.$ to $\left.302^{\circ} \mathrm{F}\right)$, the resource base would extend to non thermal areas including most of the United States east of the Mississippi. Few technological and economical barriers exist that forbid utilizing geothermal fluids in this temperature range. 1 In general, they present minimal pollution problems, and the production cost per unit of thermal energy is lower than that of most other sources of energy. Most industrial, agricultural, residential, and other processes can be adapted for direct use of low-temperature geothermal fluids 2,3 . It has been estimated that by the year 2000 , low-temperature geothermal resources could supply 16,700 to $67,000 \mathrm{MW}$ of thermal energy for direct use in the United States 4 .

Although flashed-steam, binary, and total flow systems can use geothermal fluids below $150^{\circ} \mathrm{C}\left(302^{\circ} \mathrm{F}\right)$, many geothermal power plants will probably continue to use high-temperature $\left(>150^{\circ} \mathrm{C}\right) \quad\left(>302^{\circ} \mathrm{F}\right)$ geothermal brines and steam. A comparison between binary fluid cycles using various temperatures showed that at $250^{\circ} \mathrm{C}\left(482^{\circ} \mathrm{F}\right)$, power production costs were 45 percent less than at $149^{\circ} \mathrm{C} 5$. Electric power costs can be significantly reduced by using advanced design heat exchangers, condensers, and cooling systems to improve conversion efficiency 6,7 . Nevertheless, low-temperature geothermal energy should not be restricted to electric power production. It is already used for district heating, for raising vegetables and flowers inside heated greenhouses in colder clinates, and for heat-intensive industries. However, the low number of applications that have actually been established do not reflect the iminerise pulenlidl of yeuthermal energy for industrial and other purposes.

A shortage of fresh water may be the most pressing human need in the near future. Geothermal desalination may well be up to this task by providing cheap and abundant supplies of fresh water in some areas.

Some geothermal waters contain small proportions of highly valuable minerals which ildy be capable of extraction. The low concentrations of these minerals can be offset by the high yield of the containing waters. 
The potentials of geothermal energy suggest that great economic advantages could be gained from dual or multipurpose plants combining power production with one or more other applications in a cascading temperature sequence. Such plants would enable the costs of exploration, drilling, and pipework to be shared between two or more end products.

At present, geothermal exploitation is confined to 'thermal' areas where the temperature gradient is greater than the average of $25^{\circ}$ to $30^{\circ} \mathrm{C}$ per $\mathrm{km}\left(72^{\circ}\right.$ To $87^{\circ} \mathrm{F}$ per mile). In the more extensive 'nonthermal' areas, immense reservoirs of heat lie below ground, but at such depths that they cannot be tapped economically. However, ambient temperature $\left(4^{\circ}\right.$ to $\left.26^{\circ} \mathrm{C}\right),\left(39^{\circ}\right.$ to $\left.79^{\circ} \mathrm{F}\right)$ ground water found at relatively shallow depths in nonthermal areas can be utilized in conjunction with a ground-water genthermal heat. pump for heating and cooling. Heat pumps can also use highly saline ground water. It is estimaled that 60 percent of the total land area of the United States lies above ground water which is suitable for heat pump-assisted applications 8 .

Electric power generation has been the main target of almost all geothermal research and development efforts in the U.S. Electricity can be generated at the resource site and sent over relatively long distances to the load, wherever it exists. In direct use, the thermal energy can be transmitted only over relatively short distances compared to electricity. However, a number of factors must be considered.

First, it is generally agreed that low-temperature geothermal resources are more prevalent than high-temperature resources which are commonly used for electric power generation. While it is technologically feasible to use $149^{\circ} \mathrm{C}\left(300^{\circ} \mathrm{F}\right)$ geothermal resources to generate electricity, most low-temperature resources are not suilalite for this purpose.

Secondly, it appears that a very large portion of the basic energy needs of the U.S. is for low to medium temperature heat $1 \mathrm{ng}$. Il is eslimaled lhat more than 30 percent of the total energy requirements of the U.S. can be satisfied from low-temperature geothermal resources 9 . This figure does not include ground water with temperatures less than $50^{\circ} \mathrm{C}\left(122^{\circ} \mathrm{F}\right)$. 
Thirdly, geothermal energy used directly for heating purposes is about 10 times more efficient than that used for generating electricity ${ }^{9}$. Generally, the transmission of geothermal fluids for electric power generation becomes uneconomical after 3 to $5 \mathrm{~km}(1.9-3.1 \mathrm{mi})$, but it is still feasible for direct heating up to $50 \mathrm{~km}$ (31 mi) 10 .

One limiting factor in direct use applications is the siting of homes and industries near low-temperature geothermal resources. In some cases, it may be economically feasible to send raw materials to a geothermal field for processing and to transport the manufactured products from that field to the market. Some uses such as agriculture or aquaculture are amenable to remote locations, while other uses, such as heat pump-assisted heating and cooling, are generally not limited to siting near geothermal resources.

Specific applications of geothermal energy often require a range of geothermal feed temperatures. In process design, it is usually the minimum temperature requirement which becomes a limiting factor. However, this can be overcome by drilling deeper wells or by using ground water geothermal heat pumps. Tables 1 and 2 depict the required temperature ranges for various direct uses.

Certain applications use a wide range of temperatures, and thus can be found in both Tables. In general, industrial applications require intermediate temperatures $\left(90^{\circ}\right.$ to $\left.150^{\circ} \mathrm{C}\right)\left(194^{\circ}\right.$ to $\left.302^{\circ} \mathrm{F}\right)$, while space-heating and agriculture use low temperatures $\left(4^{\circ}\right.$ to $\left.90^{\circ} \mathrm{C}\right)\left(49^{\circ}\right.$ to $\left.194^{\circ} \mathrm{F}\right)$. Figure 1 depicts the heating energy use in eight $25^{\circ} \mathrm{C}\left(45^{\circ} \mathrm{F}\right)$ temperature ranges. Note that space and water heating account for 48 percent of the energy use under $150^{\circ} \mathrm{C}\left(30^{\circ} 2^{\circ} \mathrm{F}\right)^{9}$. 
A. Industrial Processes

Low-temperature geothermal energy can be used for a variety of industrial processes. Four major industries that use geothermal heat are the food, forest products,-chemical, and mining industries. Valuable chemicals and gases in some geothermal fluids can be utilized by chemical industries.

Industries which employ several processes requiring different temperatures can use geothermal fluids in a cascading temperature sequence. That is, the geothermal effluent from one process would be directed to a process requiring a lower temperature.

While low-temperature geothermal resources below $60^{\circ} \mathrm{C}$ can be used, many commercial and industrial applications require higher temperatures. These higher temperatures $\left(60^{\circ}\right.$ to $110^{\circ} \mathrm{C}$ ) can be obtained from ambient-temperature ground water amplified by water-to-water or water-to-air heat pumps. Such heat pumps can be economically used to meet the flow and/or temperature requirements of a comnercial or industrial use without having to drill deeper wells.

Such ground-water geothermal heat pumps can be economically applied to furnish hot water for process heat, space heat, and service hot water for commerce and industry. Several heat pump firms are developing models that will deliver temperatures as high as $175^{\circ} \mathrm{C}$.

A ground-water geothermal heat pump can deliver geothermal energy simultaneously to both a districtheating system and a large industrial user. A large potential exists for commercial and industrial applications, especially in industries that use large quantities of ground water. 
TABLE 1 Required Temperatures for Low-Temperature $\left(<90^{\circ} \mathrm{C}\right)$ Geothermal Applications

\section{General \\ Use Category}

Residential

Heating \& Cooling

Agricultural

\section{Commercial \&} Industrial

\author{
Specific Applications
}

Direct Cooling

Heating \& Cooling with Heat Pumps

Direct Heating.

Refrigeration

Domestic Water Heating

Air Conditioning

Aquacul ture

Tropical Water Lily Cultivation

Soil Warming

Greenhouse Heating

Mushroom Cultivation

Animal Husbandry

Soil Sterilization

Crop Drying

Barley Germinating \& Steeping

Heating with Heat Pumps

Mining in Cold $\mathrm{Cl}$ imates

Food Processing

Metal Fabricating

Drying Diatomaceous Earth .

Drying Fish

Health Spas

Health \&

Recreation
Swimming Pool Heating

De-Icing

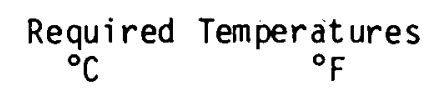

$\begin{array}{cc}0-13 & 32-55 \\ 4-38 & 39-100 \\ 38-90+ & 100-194+ \\ 58-74 & 155-165 \\ 75-90 & 167-194 \\ 82 & 180\end{array}$

10-32

26

$30-40$

$40-90+$

48-52

58-90+

60

60-90+

50-90

79

86-104

104-194+

119-125

136-194+

140

140-194t:

10-18

$16-49$

20-30

65

65

$80-90$

$82-90$

50-64

60-120

68-86

150

150

176-194

180-194

4-72

28-35

80-90
39-160

84-95

176-194 
TABLE 2 Required Temperatures For Intermediate-Temperature $\left(90^{\circ} \mathrm{C}\right.$ to $\left.150^{\circ} \mathrm{C}\right)$ Geothermal Appl ications

General
Use Category
Residential
Agricultural
Commercial \&
Industrial

Electric Power Generation
Specific Applications

Conthes Drying

Direct Heating

Greenhouse Heating

Animal Husbandry

Crop Drying

Rapid Crop Drying

Washing \& Drying Wool

Dairy Processing

Commercial Water Heating

Direct Heat-Activated Cooling

Drying of Paper

Drying \& Curing of Cement and Clay

Desal ination

Multiple Effect Evaporation

Refrigeration

Barley Malling

Beet Sugar Processing

Thermally-Driven Air Conditioning

Canning of Food

Heavy Water Production

Alumina Production

Tnmato Paste Processing

Sodi um Chloride Production

Binary Cycle System

Total Fl ow System

Fldshed-Steam System
${ }^{\circ} \mathrm{C}$ Required Temperatures

$\begin{array}{cc}120-130 & 248-266 \\ 90-107 & 194-225 \\ & \\ 90-100 & 194-212 \\ 90-115 & 194-239 \\ 90-140 & 194-284 \\ 140-150 & 284-302 \\ 100 & 212 \\ 120 & 248\end{array}$

$\begin{array}{cc}95-100 & 203-212 \\ 91-134 & 195-270 \\ 94-140 & 198-284 \\ 110 & 230 \\ 120 & 248 \\ 120 & 248 \\ 120 & 248 \\ 127 & 260 \\ 114-150 & 241-302 \\ 121-150 & 250-302 \\ 140-150 & 284-302 \\ 150 & 302 \\ 150 & 302 \\ 150 & 302 \\ 150 & 302\end{array}$

150

302

$149 \quad 300$

$150 \quad 30 ?$ 


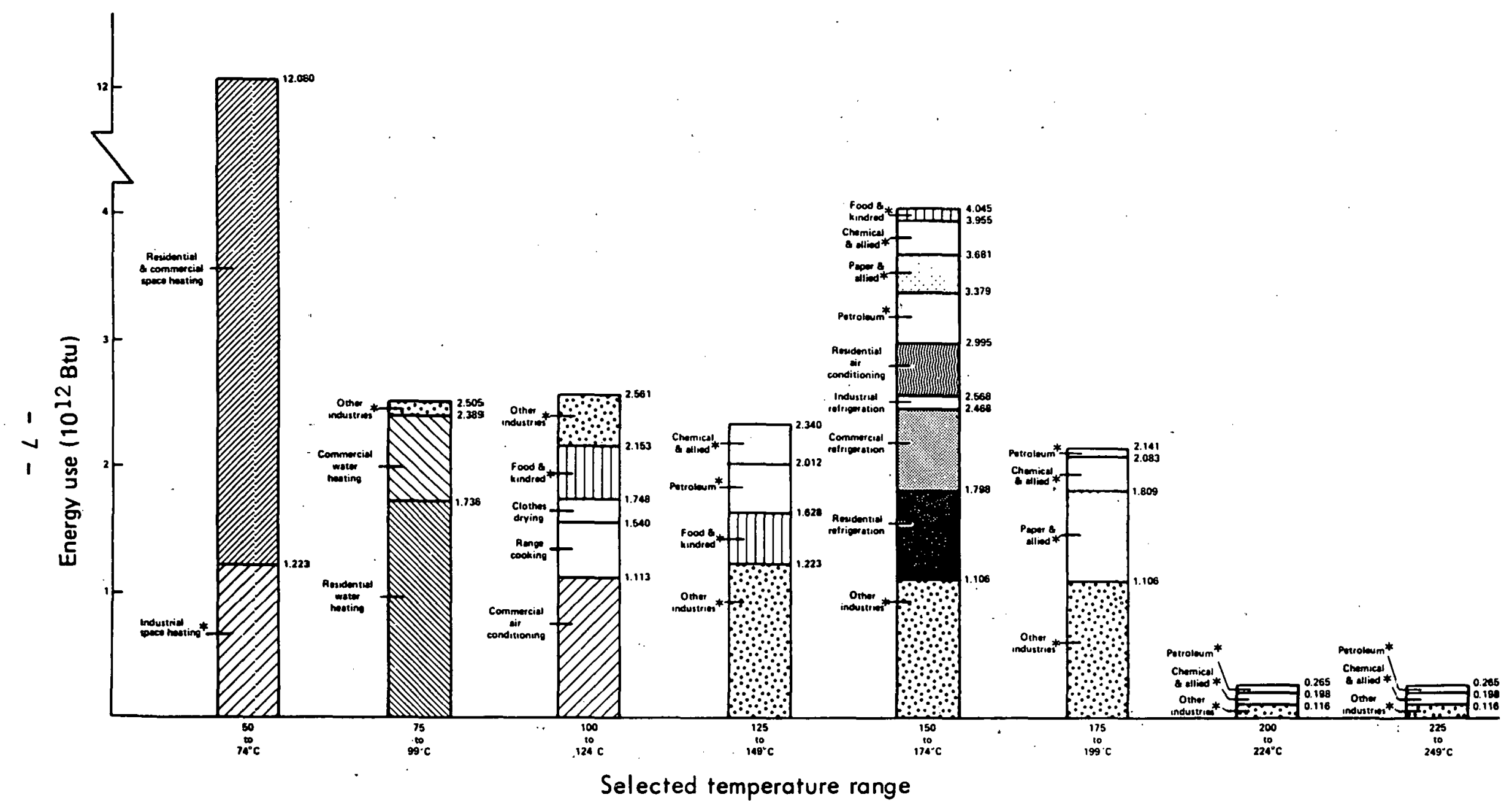

Figure 1. Estimate heating energy use in selected $25^{\circ} \mathrm{C}$ temperature ranges. ( $*$ ) indicates process steam use in sector. 9 


\section{B. Agriculture and Related Processes}

The agricultural use of low-temperature geothermal resources is already of major importance in several countries, especially in greenhouse applications. The temperature may be as low as $60^{\circ} \mathrm{C}\left(140^{\circ} \mathrm{F}\right)$ for greenhouses, and rarely exceeds $100^{\circ} \mathrm{C}\left(212^{\circ} \mathrm{F}\right)$. For soil warming in the open, the temperature needs to be only $40^{\circ} \mathrm{C}\left(104^{\circ} \mathrm{F}\right)$, and even lower initial temperatures can be used. Animal husbandry requires different temperatures to obtain opt imum thermal environmental conditions for various species in each stage of their growth. Geothermal heat can also control the growth of single-cell protein organisms.

In temperate climates, the cost of operating greenhouses with fnssil fuels amnunt.s to 15 to 20 percent of the value of the product. Geothermal energy is therefore of great economic interest in this area. However, heating greenhouses geothermally requires large quantities of water, especially if lower water temperatures are used. A 15-acre (60.7-hectare) complex of greenhouses in a mild climate would require $1,400 \mathrm{gpm}(88.3 \mathrm{l} / \mathrm{s})$ of $60^{\circ} \mathrm{C}\left(140^{\circ} \mathrm{F}\right)$ water. At present, greenhouse applications constitute over 95 percent of the agricultural uses of low-temperature geothermal fluids.

Ground-water geothermal heat pumps can be used for various agricultural purposes including: (1) simultaneous utilization of the refrigeration and heating capacities for such purposes as milk cooling and water or air heating; (2) heating and air-conditioning livestock shelters; (3) curing and preserving vegetatales, fruits, and other perishables; (1) conditioning certain seeds, grains, and nther agricultural products; (5) drying hay and other crops; greenhouse operation and soil warming; (7) freezers in combination with water heaters.

The added value of ground water for livest.nck consumption and limited lawn and garden irrigation is one factor favoring the use of ground water as a heat source and sink. Most farms al ready have supply wells, and discharge through fish ponds and land spreading rather than through injection wells is more environmentally safe for these systems than for residential or commercial systems.

The feasibility of using geothermal heat for fish hatcheries depends on several factors such as the 
temperature and quality of the geothermal fluid, availability of construction materials, and the existence of adjacent nonthermal water supplies. Fish farming can make use of fluids down to $10^{\circ} \mathrm{C}\left(50^{\circ} \mathrm{F}\right)$, since fish require only moderate environmental temperatures. Shrimp require a temperature of $27^{\circ} \mathrm{C}\left(81^{\circ} \mathrm{F}\right)$.

C. District Heating and Cooling

Low-temperature geothermal fluids are ideally suited for the space heating of buildings. In fact, geothermal water less than $90^{\circ} \mathrm{C}\left(194^{\circ} \mathrm{F}\right)$ is used in $95 \%$ of all geothermal space heating systems. 4

Space/water heating and cooling consume over one-third of the total energy usage in the U.S. The commercial sector uses 16 percent of the total energy, while the residential sector takes up 21 percent. Of the residential portion, 57.3 is used for space heating, 15.1 percent for water heating, 3.7 percent for air conditioning, 5.0 percent for cooking, 10.0 percent for small appliances, and 5.7 percent for refrigeration 12 .

In addition to space heating and cooling, low-temperature geothermal heat can provide heat for clothes drying, dishwashing, cooking, and swimming pools, as well as absorb heat for refrigeration, and provide water for' lawns, gardens, and fish ponds.

The use of geothermal energy for residential and commercial applications can be divided into district or individual heating systems. Geothermal energy most economically supplies large markets with space heating through district-heating systems; therefore, the most significant applications have been of this type.

since many cities may be sites for potential applications, the ease of converting existing buildings to geothermal systems must be considered. The three most common types of residential heating systems (baseboard convectors, forced air over hot water coils, and radiant heating panels) can readily be adapted to geothermal hot water (Figure 2 ). Baseboard convectors generally require fluid temperatures of $60^{\circ}$ to $82^{\circ} \mathrm{C}\left(140^{\circ}\right.$ to $\left.180^{\circ} \mathrm{F}\right)$, forced air can economically use fluids of $49^{\circ}$ to $71^{\circ} \mathrm{C}\left(120^{\circ}\right.$ to $\left.160^{\circ} \mathrm{F}\right)$, whereas radiant panels use fluid temperatures as low as $38^{\circ} \mathrm{C}\left(100^{\circ} \mathrm{F}\right)^{13}$. 

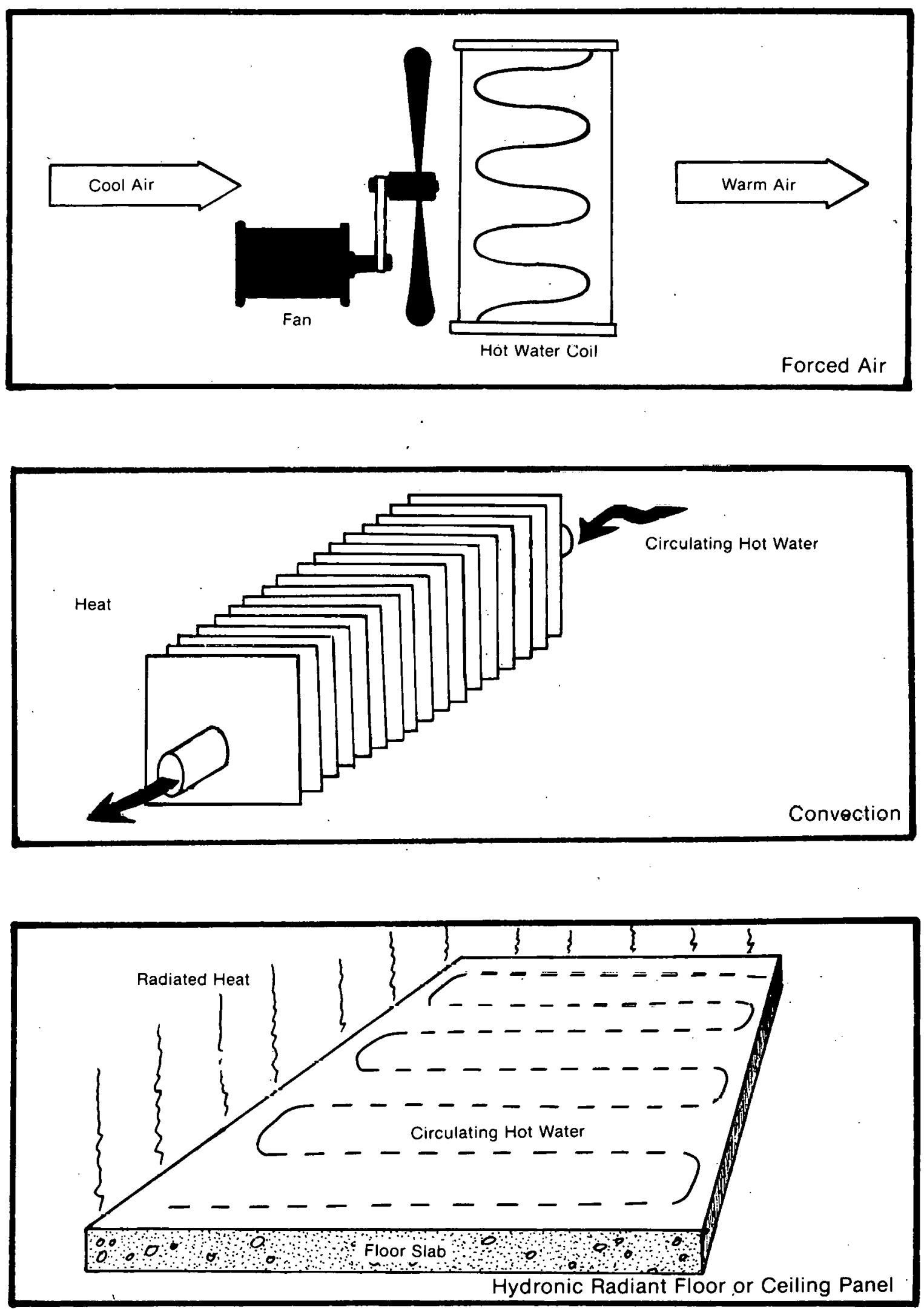

Figure 2. 
The simplest type of geothermal space heating systeli is one in which the geothermal fluids are piped directly to the user. The system requires a large well yield and high quality water but injection wells or heat exchangers are not necessary. Thus, it has low initial cost and low operating and maintenance costs. Since no intermediate heat exchangers are used, a relatively cooler resource may be ut $i 1$ ized.

If the geothermal fluid is corrosive or encrusting, a surface heat exchanger (SHE) can be used to transfer the geothermal energy to a clean working fluid, usually city water. This type of system is economical only for larger users.

The downhole heat exchanger (DHE) also uses clean city water, but circulates it in a well in which the hot formation water circulates without pumping.

The DHE system has several unique advantages over the SHE system: (1) no reservoir fluid production is required, which conserves the geothermal water resources and eliminates the risk of depleting existing hot springs; (2) surface disposal or injection wells are not needed since the system is closed loop; (3) corrosion of the piping immersed in the well occurs mostly at the air-water interface (this sometimes can be minimized by periodically pouring wax or oil down the well); (4) the need for expensive, hard to service downhole pumps is eliminated; and (5) the system can work in low permeability reservoirs which cannot supply adequate fluid production rates for direct use or SHE systems.

For lower-temperature geothermal fluids $\left(4^{\circ}\right.$ to $\left.38^{\circ} \mathrm{C}\right)$ $\left(39^{\circ}\right.$ to $\left.100^{\circ} \mathrm{F}\right)$, a heat pump can be used to yield temperatures that are high enough for residential or commercial heating without drilling deeper wells. Heat pumps transfer heat from a low temperature to a higher temperature medium. The principle is identical to the operation of a refrigerator, where heat is removed from the cold interior of the refrigerator and given off to the surrounding room air. A second fluid (such as Freon 12, 22, 11.3, or 114) is used inside the heat pump to absorb heat from the geothermal water and transfer this heat to a surrounding space (Figure 3 ). 


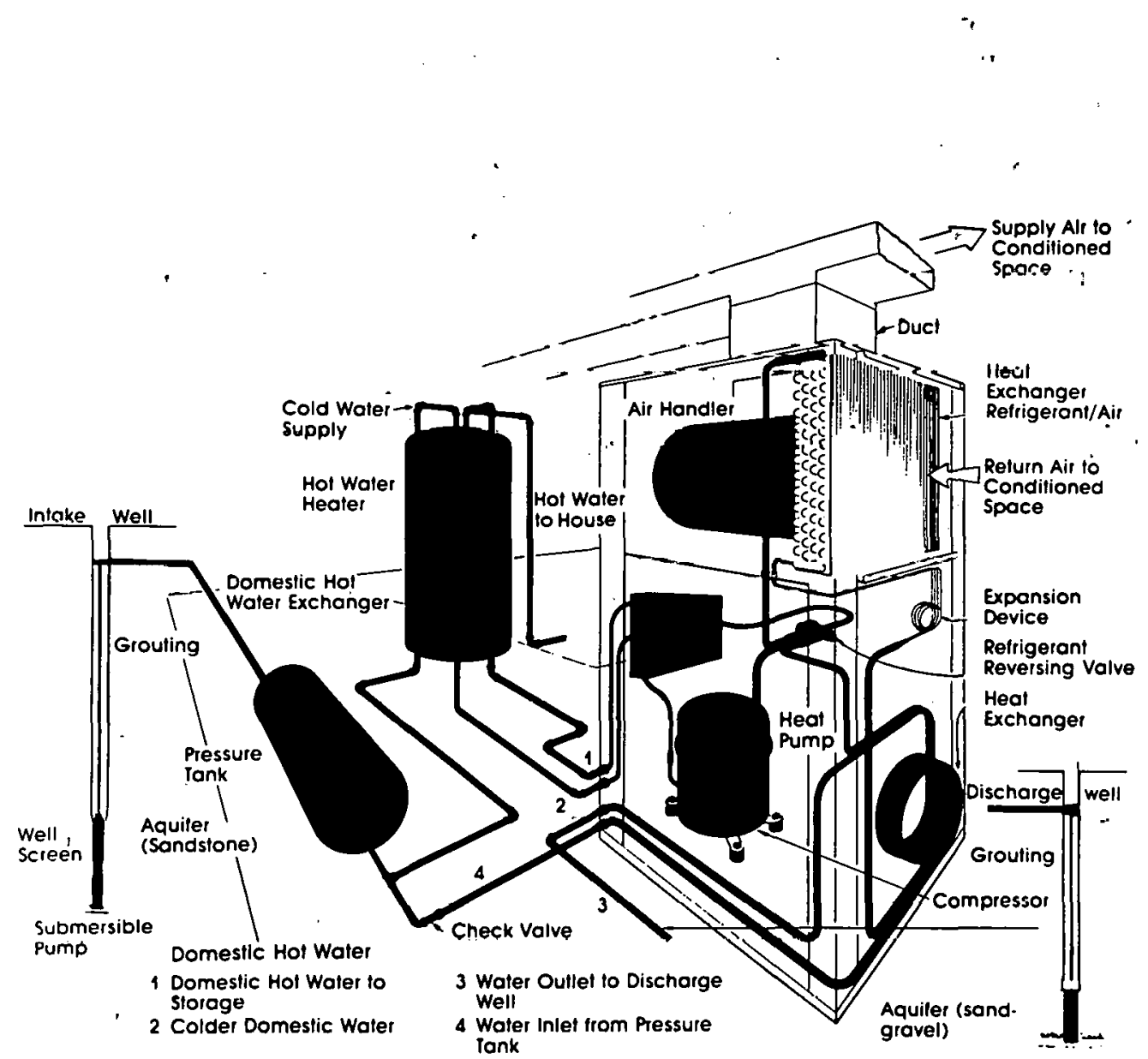

Figure 3. Ground Water Geothermal Heat Pump 
A heat pump requires electrical energy to circulate and compress the refrigerant. For each electrical energy unit used, two, three, or more equivalent units of heat energy are transferred from the source. The efficiency of the heat pump is the ratio of these two energies and is called the coefficient of performance (COP). The COP depends on the source temperature. flow rate. and particular heat pump used.

Since ground water has a relatively stable vear-round temperature, it is possible to choose a heat pump design of maximum efficiency (COP). Even ground water at $4^{\circ} \mathrm{C}\left(39^{\circ} \mathrm{F}\right)$ can be more effectively used than air (as in the more common air-to-air heat pumps). However, the warmer the water, the more efficient the system will be for heating, and the less electrical energy it will consume. Warmer water for heating can be obtained by storing the hot discharge water from the suminer cooling cycle in the aquifer. During the winter, the iniection well is used to withdraw the stored water.

The rate at which heat can be extracted from geothermal water is approximated by the formula $H=4.18(\Delta T)$ (Q) where:

$$
\begin{aligned}
H & =\text { heat rate in } \mathrm{KJ} / \mathrm{sec} \\
\Delta T & =\text { temperature reduction in }{ }^{\circ} \mathrm{C} \\
Q & =\text { flow rate in liters } / \mathrm{sec}
\end{aligned}
$$

(The number 4.18 is an approximation of the hourly heat content for each liter per second of water reduced $1^{\circ} \mathrm{C}$. )

As mentioned previously, 60 percent of the land area in the United States lies over ground-water reservoirs that have temperatures suitable for heat pump applications. Ground water flow rate depends on the permeability of the aquifer. In general, a minimum flow rate of .06 to .19 liters/sec (1 to $3 \mathrm{gpm}$ ) is required for each $3.52 \mathrm{~kJ} / \mathrm{sec}$ $(12,000 \mathrm{BTU} / \mathrm{hr})$ of heat energy. Approximately $13.5 \mathrm{mill}$ ion homes in the United States already use ground water from wells and springs for their water supply. Most of these homes lie in rural areas where power distribution is expensive.

In non-rural areas, ground-water geothermal heat pumps lend themselves well to district-heating concepts. The ground water would be the common factor for shared investment in obtaining, pumping, maintaining, and discharging the water. Common piping may be used to deliver 
ground water from a well to the area of use. The costs of installation and maintenance are mutally shared, as are the risks of resource development. Individual users would tie into a distribution piping system. To prevent too large a temperature reduction, each user would be connected in parallel. A supply line might connect main segments of city blocks or subdivisions. Each user would tap into a supply main and discharge into a return main. Thus, each user would be supplied with the same temperature water. The required flow from the geothermal well would be the sum of the flows needed for each user. Discharge water could be used directly for other purposes, depending on its lemperature, water quality, and flow rate.

The economic benefit of the district heat pump system can further increase if the annual use factor increases (i.e. by increasing the time the district heat pump system operates at tull capacity). It may be necessary to provide an industrial load or similar annual uniform heat load to increase the annual use factor (load factor) to an economic number.

The use of a fossil fuel-fired peaking system should be considered in any economic feasibility study. The peaking system (using on-site stored energy such as fuel oil) would meet the load during the coldest period (generally five percent of the time), thus eliminating the need to expand the geothermal system as is done in Reykjavik, Iceland.

\section{Miscellaneous Applications}

Hot springs and warm mineral springs have been used for centuries for bathing, recreational, and health purposes. In recent years, such springs have become more accessible to many people. The occurrence of such springs is limited to certain areas of the country. However, geothermal wells can tap water of similar temperature and chemistry. The water from geothermal springs or wells is used for heating swimming pools, mineral baths, mud baths, and steam baths. Acid and basic mud baths are used for the treatment of rhelımatic diseases. Potahle mineral water from warm mineral springs is used as a tonic. Recreational swimming pools for schools, municipalities, and individual homes can use geothermal. energy for year-round heating.

Geothermal hot water can also be used to melt snow on highways and sidewalks. A network of pipes which circulate geothermal fluid is laid and then paved over with cement or asphalt. The same pipes can be used to prevent freezing of fire fighting water. 
APPENDIX B. HYDROGEOLOGIC FACTORS AFFECTING THE DESIGN AND CONSTRUCTION OF LOW-TEMPERATURE GEOTHERMAL WELLS

Before a low-temperature geothermal reservoir can be used for any purpose, it must be evaluated with that purpose in mind. It should have enough porosity and permeability to maintain the correct balance between a heat source and a heat carrying fluid (usually hot water), and the storage volume of the reservoir must be large enough to justify its further evaluation and exploitation. Although the permeability, heat content, and volume may be adequate, the working fluid may be high in dissolved solids and create corrosion and incrustation problems in wells and process equipment.

The permeability of the formation depends on the interconnected pore spaces as well as the degree of fracturing or secondary permeability. Permeability usually decreases with depth but fracture permeability may increase with depth.

The standard technique for exploiting geothermal resources is the "doublet" method, which consists of a production and injection well. The injection well disposes of dissolved solids which can create severe pollution problems. However, plugging of the formation by scale can be a problem. Injecting the used fluid also enables better thermal utilization of the reservoir; on its way from the injection to the production well, the cold inlet water extracts part of the heat contained in the rock matrix. After a certain time, the thermal influence of the injection well reaches the production well, causing a slow drawdown of temperature. The lifetime of the doublet system depends on the reservoir thickness, porosity, temperature, withdrawal rate, and production/injection well spacing.

Chemical problems can cause severe difficulties in the exploitation of geothermal reservoirs. Low-temperature geothermal fluids, especially those from deep aquifers, may have low $\mathrm{pH}$ and contain dissolved solids in large amounts (up to 25,000 ppr.). This can cause clogging of the formation surrounding the well and severe corrosion and incrustation of well casing and screen. Thus, the lifetime of a doublet production system can be limited by the change of solution equilibria in time rather than by the thermal drawdown. The chemical composition of various types of geothermal brines and the factors involved in corrosion and scaling are discussed below. 


\section{WATER QUALITY}

Precipitation (meteoric water) usually contains dissolved gases which lower its pH below 7 (acid condition). Upon reaching the earth's surface, the water may pick up organic acids in the soil which further increases its acidity. As this meteoric water percolates through so il and rocks, it dissolves minerals and forms salts which are taken into solution. The amount and character of the salts depend upon the chemical composition of the water, the mineralogical and physical structure of the rocks encountered, and the temperature, pressure, and duration of contact.

If geothermal reservoirs are recharged with meteoric water, the rock will be leached and the heat-producing strata will become depleted of certain minerals. Thus, over a period of time, the brine composition will be altered and the concentration of some constituents will be reduced. This may extend the service life of production and injection wells and decrease maintenance costs if corrosion and scaling due to brine chemistry is a problem.

The withdrawal of hot fluid from low-temperature geothemal reservoirs results in the flow of steam, water, or a mixture of both. The water contains total dissolved solids varying from that of ordinary well water up to concentrations over $35,000 \mathrm{ppm}$.

The concentration of constituents and the ratios between certain constituents are controlled in solution by mineral solubility, mineral equilibria, and solution $\mathrm{pH}$. Thus, silica, calcium, magnesium, rubidium, lithium, sulfate, bicarbonate, and carbonate concentrations, as well as the ratio of sodium to potassium, are controlled within 1 imits imposed by the temperatures of the systems and the salinities of the waters. When the temperature of geothermal systems are similar, the concentrations and ratios of some constituents are likely to be the same irrespective of the major rock type present.

\section{A. TYPES OF LOW-TEMPERATURE GEOTHERMAL BRINES}

Tables 1 to 3 list the concentrations of various chemical constituents in 10 -temperature $\left(<150^{\circ} \mathrm{C}\right),\left(\left\langle 302^{\circ} \mathrm{F}\right)\right.$ geothermal brines. Each analys is is classified as one of four chemical types: alkal $i$ chloride $(A C)$; acid sulfate (AS); acid sulfate-chloride (ASC); or bicarbonate. 
Table 1 Chemical Analyses of Alkali-Chloride Geothermal Waters (concentrations in ppm unless otherwise noted)

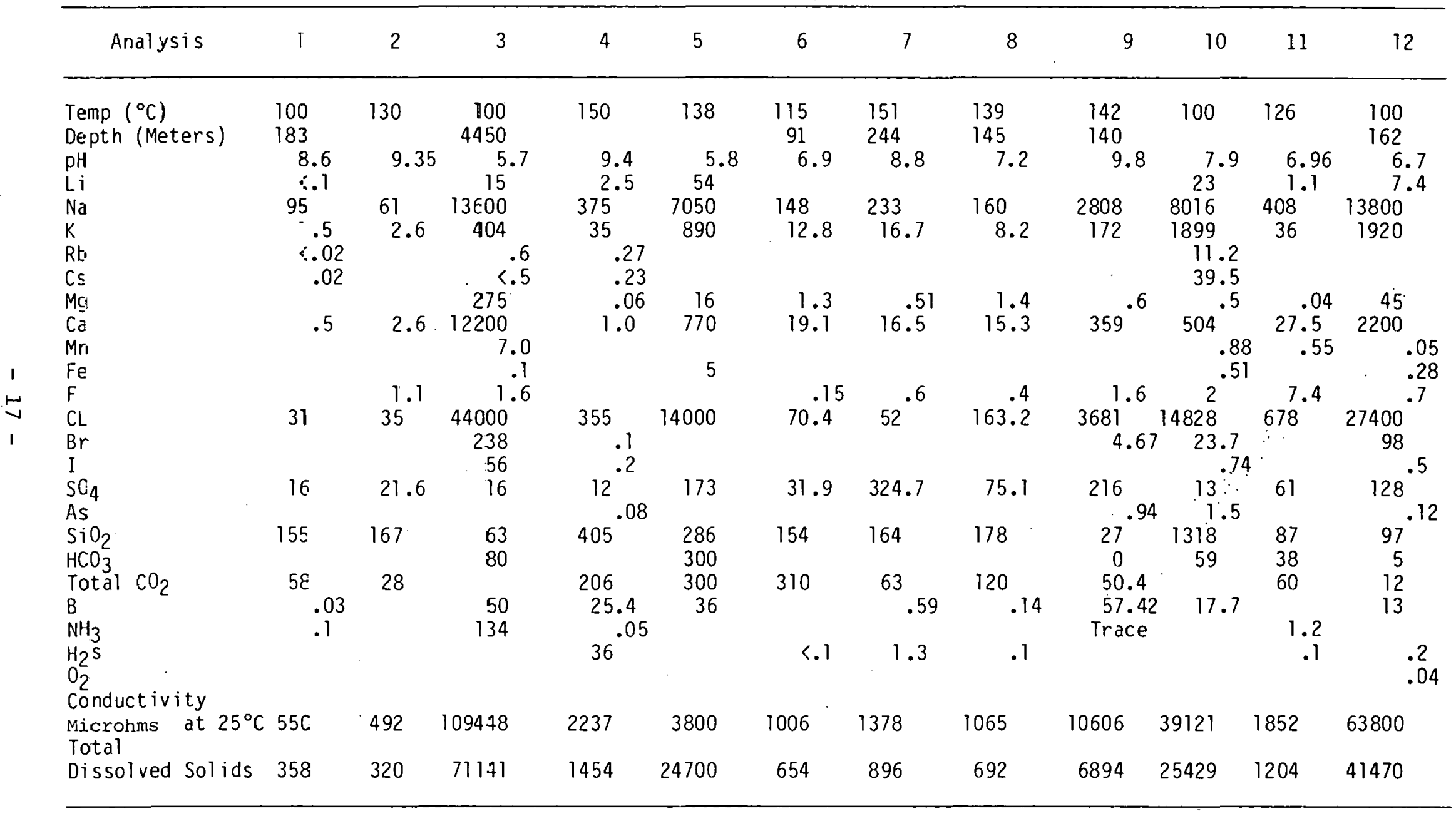

References 1. 14, p. 62;2. 10, p. $282 ; 3.14$, p. 38;4. 14,p. 332; 5. 15, p. 34;6., 7., 8., 16, p. 854; 9. 17, p. $8 ; 10 ., 11.18$, p. $1-4 ; 12$. 19, p. F41-54; 
Table 2 Chemical Analyses of Acid Sulfate and Acid Sulfate-Chloride Geothermal Waters (concentrations in ppm unless otherwise noted)

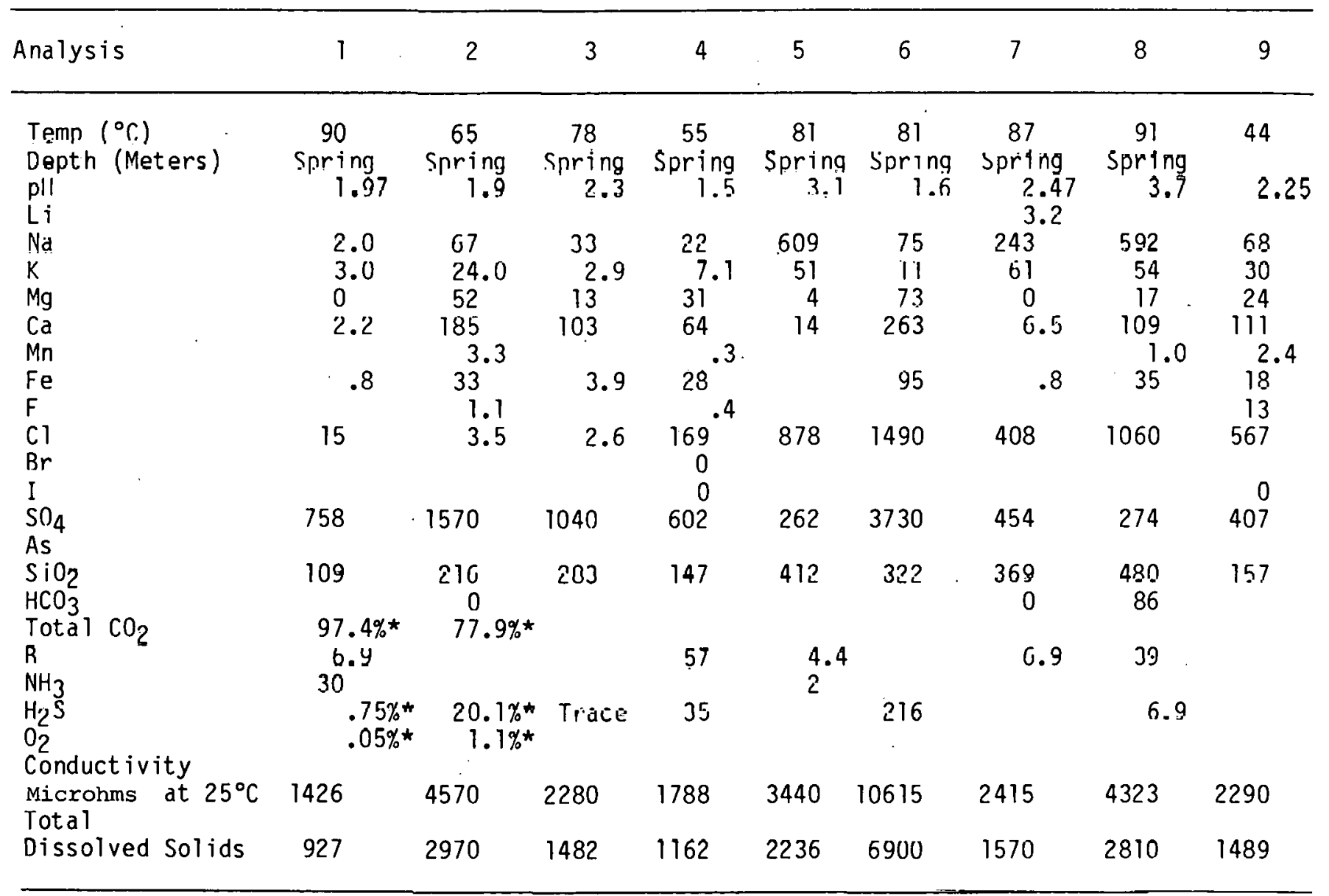

References 1. 20, p. 50;2., 3.,6.,7., 8., 9. 19, p.F41-54;4., 5. 20, p.50

*Mole percent of total gàs 
Table 3 Chemical Analyses of Bicarbonate Geothermal Waters (concentrations in $p p m$ unless otherwise noted)

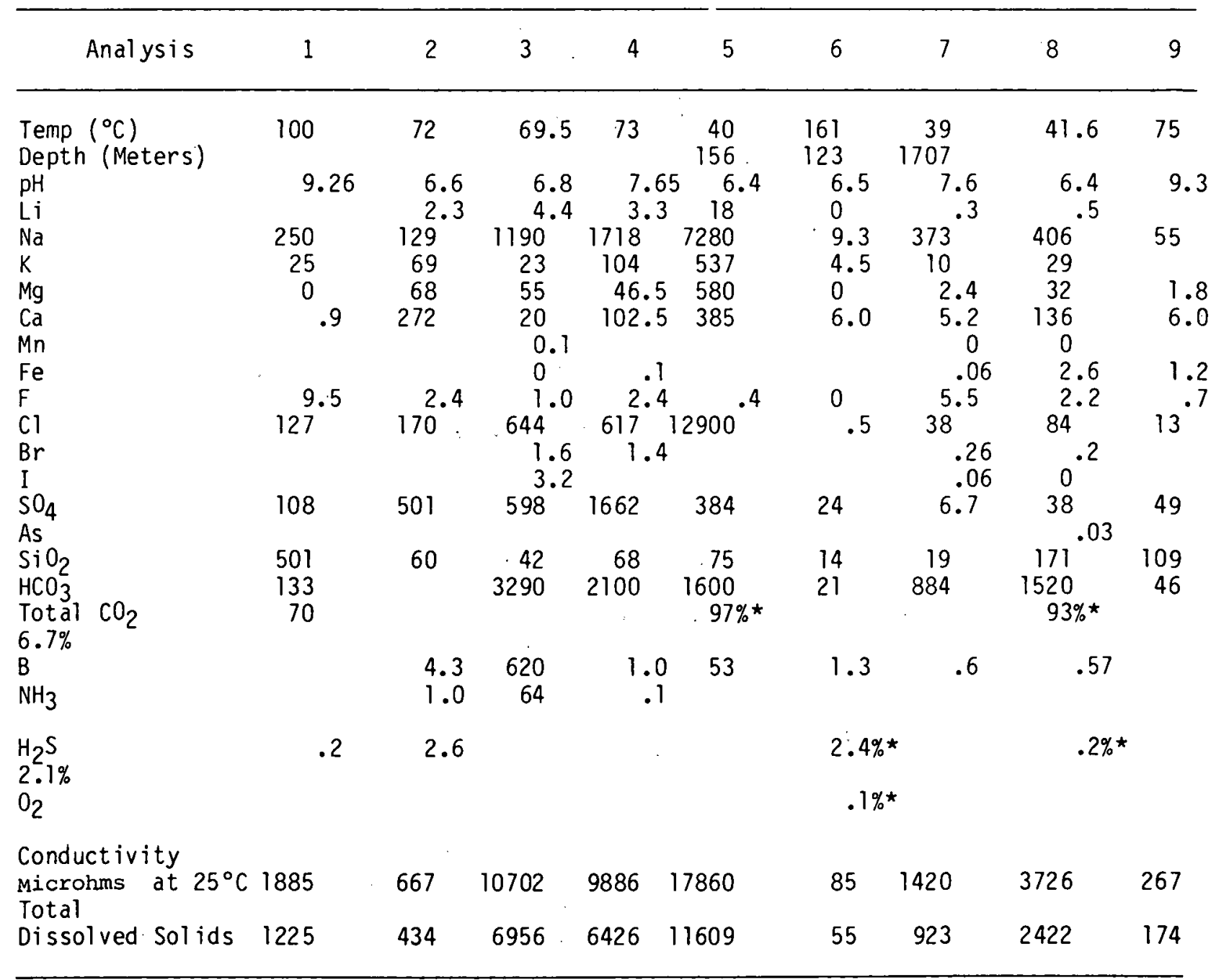

References 1.,2. 20,p.50;3., 4. 14, p.38; 5.,6., 7., 8., 9. 19, p. F41-54

*Mole percent of total gas 
It is interesting to note that brines with temperatures exceeding $100^{\circ} \mathrm{C}\left(212^{\circ} \mathrm{F}\right)$ are usually alkali chloride type, while those with temperatures less than $70^{\circ} \mathrm{C}\left(158^{\circ} \mathrm{F}\right)$ are predominantly bicarbonate type. Brines of intermediate temperatures are acid sulfate or acid sulfate-chloride type.

The dissolved salts in $A C$ waters are mainly sodium and potassium chlorides, although appreciable calcium concentrations may occur in the more concentrated waters (Table 1, analyses $3,5,10$, and 12). The waters also contain high concentrations of silica, and usually significant concentrations of sulfate, bicarbonate, fluoride, ammonia, and boric acid. The chloride/sulfate ratio is usually high, and the $\mathrm{pH}$ ranges from slightly acid (pH 5) at great depths to slightly alkaline $(\mathrm{pH} 9.5)$ as the water comes to the surface and loses steam and $\mathrm{CO}_{2}$. Carbon dioxide and hydrogen sulfide are the major dissolved gases. AC water is lhe most. common type in large underground wet steam reservoirs.

AS waters (Table 2, analyses 1-4) which are low in chloride content are common in fumarolic areas where steam at about $400^{\circ} \mathrm{C}\left(752^{\circ} \mathrm{F}\right)$ rises from a dry steam reservoir and condenses at the surface. Hydrogen sulfide in the steam is subsequently oxidized to form $\mathrm{H}_{2} \mathrm{SO}_{4}$. The water may contain large and varying concentrations of cations leached from rocks surrounding the pools. The springs containing AS waters usually have little or no discharge and often contain large amounts of suspended clay material.

Since AS water is predominantly surface water, it would not bc associated with geotlieimal wells. However, it may infiltrate to mix with AC waler, forming ASC water (Table 2, analysis 5-9). ASC waters may also form when sulfide in $A C$ waters at deep levels becomes oxidized to bisulfate ions through an association with oxidized lavas. The water at these levels may have a near-neutral $\mathrm{pH}$ due to the neutralizing and buffering action of the confining rocks. However, since the dissociation constant. for bisulfate ion increases markedly with a lowering of temperature, a high-bisulfate water of close to neutral pH underground may become acidic on rising to cooler conditions at the surface. Thus, the pH at the water could vary from 2 to 5 and be more corrosive. 
Bicarbonate waters can be subdivided into sodium bicarbonate, calcium bicarbonate, and sodium chloride bicarbonate waters. The latter type, represented by Table 3 , analysis 5, is rare. Generally, bicarbonate waters contain low chloride, high bicarbonate, and variable sulfate. Sodium is often the main cation since calcium carbonate is not very soluble at high temperatures and potassium and magnesium are fixed in clays. Calcium bicarbonate waters (Table 3, analyses 2 and 8 ) commonly occur as low-temperature travertine depositing springs. Water of this kind has low heat content, and calcite deposition in well casings and screens presents a severe drawback to its utilization.

Bicarbonate waters may occur near the surface in volcanic geothermal areas where steam containing carbon dioxide and hydrogen sulfide condenses in an aquifer. Under stagnant conditions, reaction with rock produces neutral $\mathrm{pH}$ bicarbonate or bicarbonate-sulfate solutions (Table 3 , analyses 2-4). Bicarbonate waters of greater complexity are also common at deep levels in geothermal systems within. metamorphic or sedimentary rock.

\section{B. CORROSION IN GEOTHERMAL ENVIRONMENTS}

Geothermal corrosion is highly specific and depends greatly on the nature of the geothermal fluid, temperature, fluid velocity, duration of exposure, and type of materials used in well construction. The variability in composition of geothermal fluids from field to field and from well to well adds to the complexity of materials selection. The most reliable selection method would be to make extensive corrosion tests in low-temperature geothermal fluids for various metallic and nonmetallic materials. Such tests have been performed in various low-temperature geothermal brines $6,17,21,22$ and in sea water 23. Results of these tests are presented in Table 4.

1. Corrosive Chemicals. Geothermal fluids contain six key chemical species that cause chemical corrosion of metallic construction materials: 1) hydrogen ion $(\mathrm{pH})$ 2) chloride ion 3) hydrogen sulfide 4) carbon dioxide, carbonate, and bicarbonate ion 5) ammonia, ammonium ion 6) sulfate ion. Examples of other chemical species that also cause chemical corrosion but are either less common or less aggressive are fluoride ion, heavy metals, boron, and oxygen. The importance of a given species depends on the material used, 
TABLE 4 RESULTS OF GEOTHERMAL CORROSION TESTS

\begin{tabular}{|c|c|c|c|c|c|c|c|c|c|c|c|c|}
\hline Materia & & $\begin{array}{l}\text { Temp } \\
{ }^{\circ} \mathrm{C}\end{array}$ & - $\mathrm{pH}$ & $\mathrm{O}_{2}$ & $\begin{array}{l}\mathrm{HCO}_{3}{ }^{\mathrm{Te}} \\
\mathrm{ppm}\end{array}$ & $\begin{array}{l}\text { Condi } \\
\mathrm{H}_{2} \mathrm{~S} \\
\mathrm{ppm}\end{array}$ & $\begin{array}{r}\text { ions } \\
\mathrm{SO}_{4} \\
\mathrm{ppm}\end{array}$ & $\begin{array}{l}\mathrm{CL} \\
\mathrm{ppm}\end{array}$ & $\begin{array}{l}\mathrm{NH}_{3} \\
\mathrm{ppm}\end{array}$ & $\begin{array}{l}\text { Type of } \\
\text { Corrosion }\end{array}$ & $\begin{array}{l}\text { Rate } \\
\text { (mpy) }\end{array}$ & Ref. \\
\hline $\begin{array}{c}\text { Carbon } \\
\text { " }\end{array}$ & Steel & $\begin{array}{c}130 \\
105 \\
1 "\end{array}$ & $\begin{array}{l}5.7 \\
6.7\end{array}$ & $\begin{array}{l}N \\
" 1 \\
X\end{array}$ & $\begin{array}{r}46 \\
30 \\
11\end{array}$ & $-\overline{11}$ & $\begin{array}{l}20 \\
10 \\
11\end{array}$ & $\begin{array}{l}11,800 \\
11,800\end{array}$ & ${ }^{83}{ }_{N}^{N}$ & $\begin{array}{c}\text { General } \\
" \\
"\end{array}$ & $\begin{array}{r}3.2 \\
17.3 \\
40.9\end{array}$ & $\begin{array}{l}6 \\
1 " \\
11\end{array}$ \\
\hline$"$ & & 133 & 7.2 & $\hat{N}$ & 64 & 1.1 & 60 & 976 & "... & $\begin{array}{l}\text { Generdl } \\
\text { Pitting }\end{array}$ & $\begin{array}{r}1.8 \\
4.3 .5\end{array}$ & $"$ \\
\hline$"$ & & $"$ & $"$ & $"$ & . & $"$ & $"$ & $"$ & $"$ & Crevice & 33.6 & $"$ \\
\hline$"$ & & 1005 & 6.1 & $\begin{array}{l}N \\
X\end{array}$ & 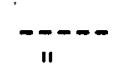 & ---- & -- & 155,000 & $-\cdot$ & Gellerd & $\begin{array}{l}4.2 \\
5.8\end{array}$ & 21 \\
\hline " & & $"$ & 7.6 & $\stackrel{\ddot{N}}{X}$ & " & $"$ & 16 & 18,000 & 39 & " & $\begin{array}{l}1 \% .3 \\
40.9\end{array}$ & $"$ \\
\hline$"$ & & $\begin{array}{r}71 \\
100\end{array}$ & 6.0 & $\widehat{N}$ & N & 30 & -- & 1,500 & --- & $"$ & $\begin{array}{l}3.0 \\
0.4\end{array}$ & 22 \\
\hline$" 1$ & & 60 & ." & $x$ & ---- & 20 & $"$ & $"$ & $"$ & $"$ & 30.0 & $"$ \\
\hline " & & $\begin{array}{l}140 \\
" 1\end{array}$ & 9.8 & $\begin{array}{l}N \\
X\end{array}$ & 0.0 & "-- & $\begin{array}{r}216 \\
11\end{array}$ & $\begin{array}{c}3,681 \\
11\end{array}$ & Trace & Pitting & $\begin{array}{l}51.0 \\
205\end{array}$ & 17 \\
\hline " & & $\begin{array}{l}80 \\
" 1\end{array}$ & 1.5 & $\hat{N}$ & $10^{.16}$ & " & 1.5 & " & $i^{005}$ & " & $\begin{array}{r}6.0 \\
35.0\end{array}$ & " \\
\hline " & . & $\begin{array}{l}95 \\
95 \\
11\end{array}$ & $\begin{array}{l}4.5 \\
4.5\end{array}$ & $\hat{N}$ & $\begin{array}{l}1.6 \\
11\end{array}$ & " & 10.6 & " & " & " & $\begin{array}{l}2.0 \\
6\end{array}$ & " \\
\hline 304 SS & . & $\begin{array}{c}133 \\
11\end{array}$ & $\begin{array}{l}7.2 \\
11\end{array}$ & $\begin{array}{l}N \\
" 1 \\
" 1\end{array}$ & $\begin{array}{r}64 \\
11 \\
11\end{array}$ & ${ }_{11}^{.1}$ & $\begin{array}{c}60 \\
" 1\end{array}$ & $\begin{array}{l}776 \\
1 " \\
11\end{array}$ & " & $\begin{array}{l}\text { General } \\
\text { Pitting }\end{array}$ & 30.02 & $\begin{array}{l}6 \\
11 \\
11\end{array}$ \\
\hline$"$ & & " & $"$ & " & $"$ & $"$ & " & " & . " & Crevice & $x$ & $"$ \\
\hline " & & $\begin{array}{r}71 \\
100\end{array}$ & $0^{6}$ & $\begin{array}{l}N \\
11\end{array}$ & $\bar{N}$ & 30 & --- & 1,500 . & $-\ldots$ & Concral & $\begin{array}{l}0.0 \\
0.0\end{array}$ & $2 ?$ \\
\hline$"$ & & 60 & " & $\begin{array}{l}X \\
11\end{array}$ & "1 & 20 & --- & $"$ & $-\cdots$ & $\begin{array}{c}\text { " } \\
\text { Pitting }\end{array}$ & 0.0 & \\
\hline " & & 140 & 9.8 & $\begin{array}{l}N \\
X\end{array}$ & $\begin{array}{l}0 \\
" 1\end{array}$ & 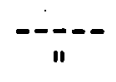 & 216 & $\begin{array}{l}3,681 \\
11\end{array}$ & Trace & Pitting & $\begin{array}{c}6 \\
10\end{array}$ & $\begin{array}{r}17 \\
11\end{array}$ \\
\hline$"$ & & $\begin{array}{l}80 \\
11\end{array}$ & 1.5 & $\begin{array}{l}\hat{N} \\
X\end{array}$ & ${ }^{.16}$ & ---- & 1.5 & "-- & $i^{.005}$ & Grain & $\begin{array}{l}0.8 \\
5.5\end{array}$ & " \\
\hline " & & $\begin{array}{l}95 \\
11\end{array}$ & 4.5 & $\hat{N}$ & 1.6 & "-- & 11.6 & ". & " & " & $\begin{array}{l}1.0 \\
1.2\end{array}$ & " \\
\hline 316 SS & & $\begin{array}{l}130 \\
105\end{array}$ & $\begin{array}{l}5.7 \\
6.7\end{array}$ & $\begin{array}{l}N \\
" 1\end{array}$ & $\begin{array}{l}46 \\
30 \\
\text { " }\end{array}$ & 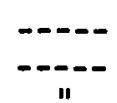 & $\begin{array}{r}20 \\
10 \\
11\end{array}$ & $\begin{array}{l}11,800 \\
11,800\end{array}$ & ${ }_{N}^{83}$ & General & $\begin{array}{l}<.05 \\
<.05\end{array}$ & $\begin{array}{l}6 \\
" 1 \\
11\end{array}$ \\
\hline$"$ & & $"$ & 6.7 & $x$ & $"$ & $"$ & $"$ & $"$ & $"$ & General & ز.0. & $"$ \\
\hline$"$ & & $"$ & $\because 7$ & " & $"$ & $"$ & $"$ & $"$ & $"$ & Crevice & $<.1$ & $"$ \\
\hline " & & 133 & 7.2 & $\begin{array}{l}N \\
" 1\end{array}$ & 64 & $n^{.1}$ & 60 & $l_{11}^{776}$ & --- & $\begin{array}{l}\text { General } \\
\text { Pitting }\end{array}$ & 39.22 & " \\
\hline$"$ & & $"$ & $"$ & $"$ & $"$ & $"$ & $"$ & $"$ & $"$ & Crevice & 41.0 & $"$ \\
\hline$"$ & & 105 & 6.1 & $N$ & ---- & $-\cdots$ & $-x=-$ & 155,000 & ---- & General & 0.0 & 21 \\
\hline$"$ & & $"$ & $"$ & $x$ & $"$ & $"$ & $"$ & $"$ & $"$ & $\begin{array}{l}\text { Crevice } \\
\text { General }\end{array}$ & $\begin{array}{l}<.1 \\
4.0\end{array}$ & " \\
\hline
\end{tabular}


TABLE 4 cont.

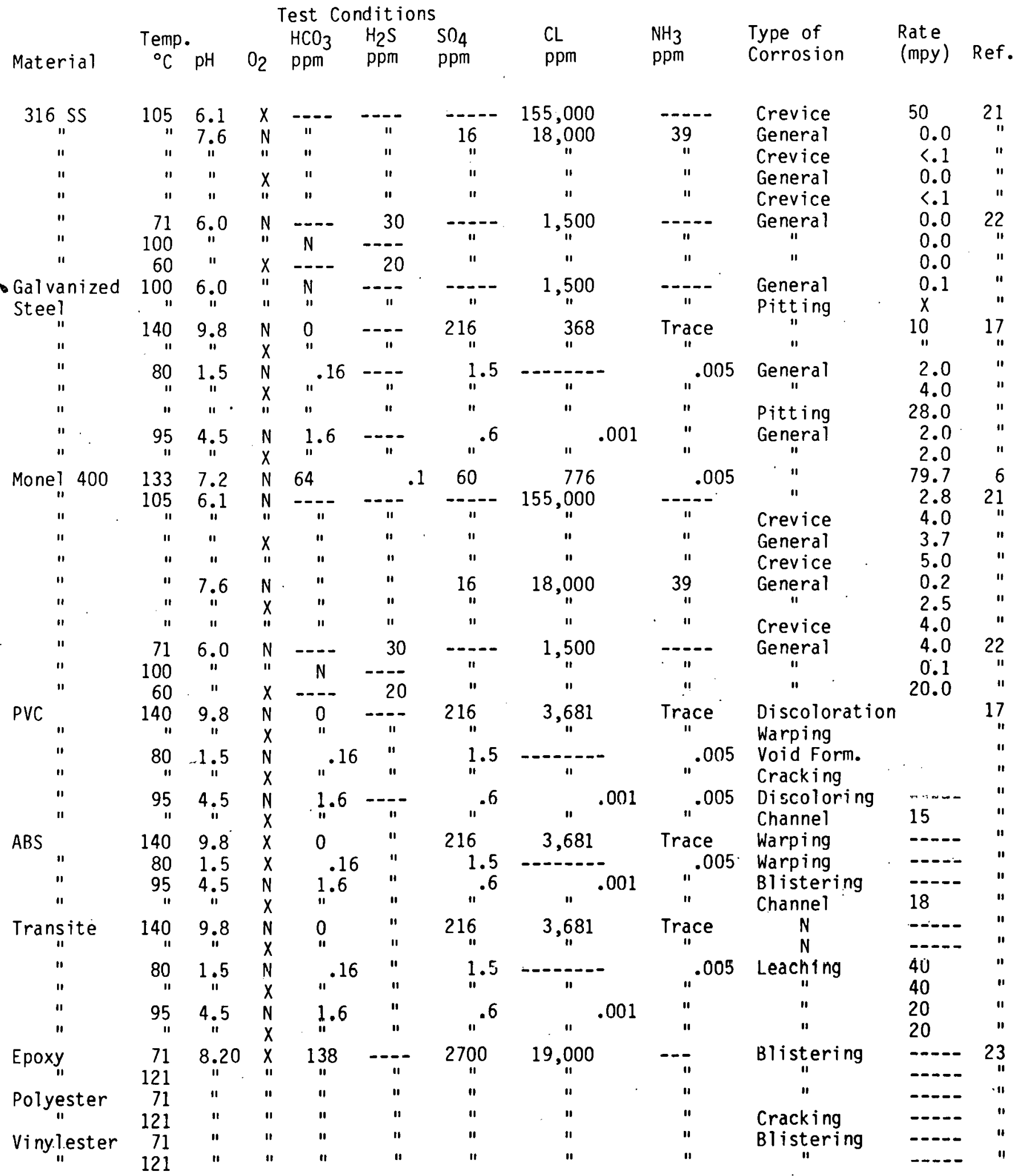


TABLE 4 cont.

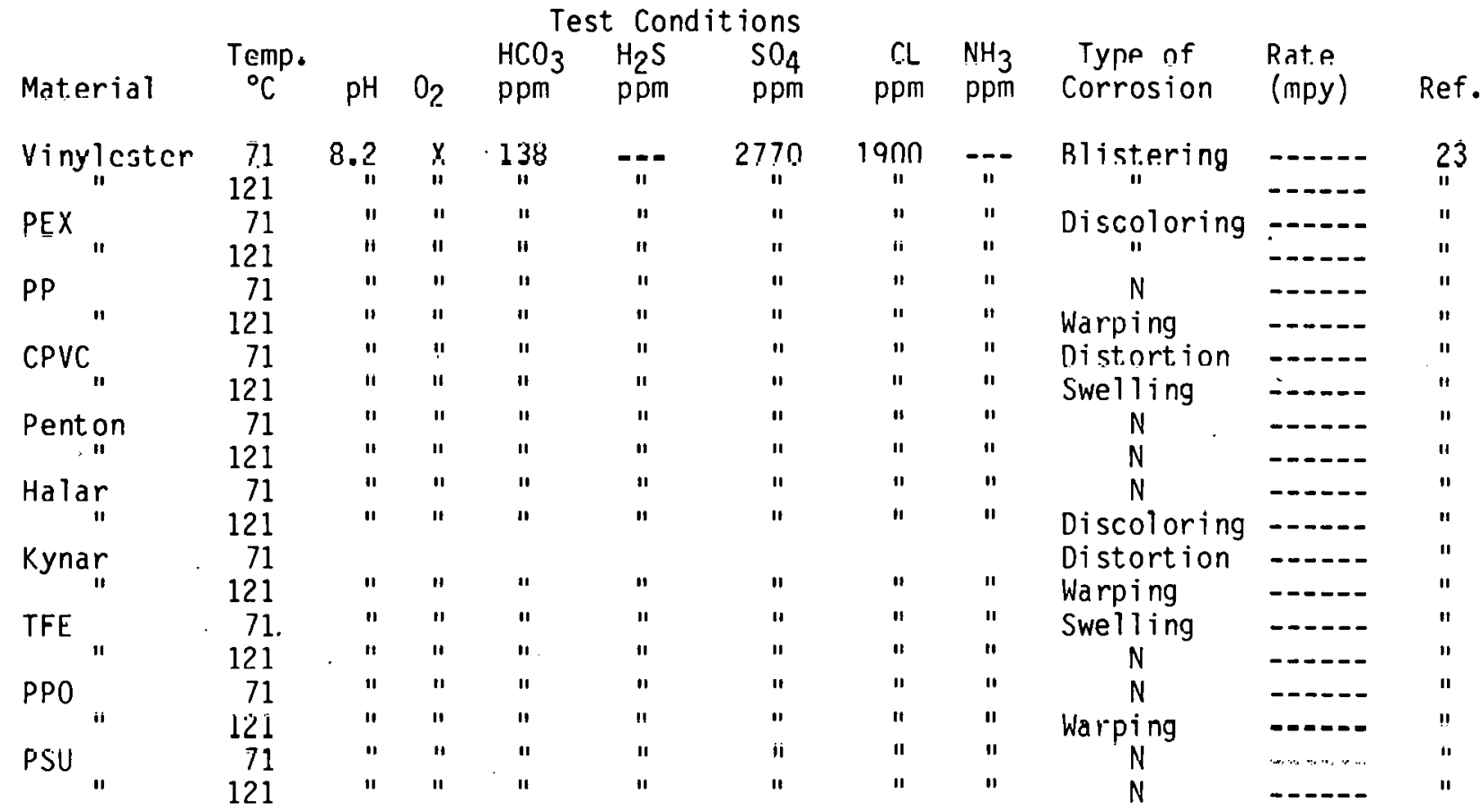

Key to Table

$\mathrm{N}=$ None

$X=$ Present but not quantified 
its concentration relative to other species, its interaction with other species, temperature, and the form of attack (uniform, localized, stress cracking) 6. It is important to note that geothermal fluids may not need a high amount of dissolved solids or a high temperature to cause corrosion if certain chemical species are present in large enough concentrations.

Dissolved oxygen is a major factor in the degree of corrosivity of water. The presence of oxygen increases the corrosivity of chloride. Oxidation of $\mathrm{H}_{2} \mathrm{~S}$ to form sulfuric acid also increases the acidity of the brine. Fortunately, geothermal brines are generally oxygen-free and corrosion rates are low. However, oxygen can enter the system through the injection well system, the production well during maintenance and repairs, leakage of oxygen-rich shallow ground water, or leaks in the brine storage and transmission components. The addition of minute amounts of oxygen to a low-temperature geothermal system can greatly increase the chance of severe localized corrosion of normally resistant metals. Carbon steel, low-alloy steels, and grey cast iron experience excessive corrosion under aerated conditions ( 3 to 20 times greater than in oxygen-free water). Aerated or acidic ground water close to the surface can cause serious external corrosion of the well casing. This can usually be prevented by using multiple casings near the surface with careful cementing of the spaces between the casings. Also, an inert gas blanket in the annular space between the casing and the pump column will exclude air and control corrosion. If dissolved oxygen enters the well it can be removed through the process of degasification 18 .

2. Temperature. Temperature has a considerable control over the corrosivity of geothermal waters. This is due predominantly to the increase in $\mathrm{H}_{2} \mathrm{~S}$ and $\mathrm{CO}_{2}$ in the steam phase with the rise in temperature. The rates of many chemical reactions are affected by increasing temperat ure (on the average two to three times for every $10^{\circ} \mathrm{C}\left(18^{\circ} \mathrm{F}\right)$ ). The shifting of various dynamic equilibria such as the concentration of carbonates, sulfates, $\mathrm{pH}$, or electro-conduct ivity are also affected by temperature changes.

In general, the corrosion rate of iron doubles for each $22^{\circ} \mathrm{C}\left(40^{\circ} \mathrm{F}\right)$ rise in temperature. In an open system, the corrosion rate of iron increases with an increase in 
temperature up to $80^{\circ} \mathrm{C}\left(176^{\circ} \mathrm{F}\right)$ (depending upon $\mathrm{pH}$, dissolved salts, etc.), and then decreases quite sharply to a very low value at the boiling point of water. This is due to a decrease in the solubility of oxygen with temperature. However, oxygen cannot escape with a rise in temperature in a closed system such as a geothermal well where the water is not exposed to the atmosphere or where the supply of external air is significantly restricted. Consequently, the corrosion rate of iron increases with a rise in temperature unt il all oxygen is consumed.

3. Fluid Velocity. Beyond the flash point in geothermal well 1 , steam and gases separate from the liquid, resulting in high velocity gas flow with entrained liquids. This may subject the well casilly to erosion-corrosion, esperially when the steam contains hydrngen sulfide. In general, erosion-corrosion is enhanced by increased solution velocitics, primarily due to the scourlng action at very high flow rates. Erosion-corrosion is also increased by the change from laminar flow to turbulence that accompanies very high flow rates, such as near well screens. Turbulence introduces far greater agitation into the system and alters mass transport effects. Laminar flow is often interrupted by projections or pits in the casing due to incrustation and corrosion.

The flow velocity of electrolytes over same metals can have a beneficial effect by maintaining a supply of corrodents at the metal surface to facilitate the formation of protective films. The pitting rate of stainless steel casing can be reduced by a flowing action which prevents deposit fömalion.

\section{SCALING}

Scale incrustation commonly occurs in geothermal wells, and arises mainly from the deposition of soluble or suspender constituents in geothermal brines. Sading causes decreased fluid productivity and eventually plugs the well casings. Various methods of geothermal brine treatment are available for the control of scaling in injection wells 18. The economics of brine treatment is beyond the scope of this report and will not be presented.

Important parameters affecting scaling in geothermal wells are: 
1) Brine composition

2) Temperature and temperature changes

3) Pressure changes, including partial pressure change in $\mathrm{CO}_{2}, \mathrm{H}_{2} \mathrm{~S}, \mathrm{NH}_{3}$

4) Velocity and turbulence

5) Residence time in the well

6) Fluid phase (steam or water)

7) Salt carryover in steam phase

8) Type of casing material.

1. Silica Deposition. Silica has rarely been detected within the casing of production wells that discharge continuously except in the highest-temperature fields (up to $\left.350^{\circ} \mathrm{C}\right)$. Therefore, silica scale deposition is highly unlikely in low-temperature geothermal wells. However, injection wells in high-temperature fields may become incrusted with silica if the brine is not kept in holding ponds or treated to allow the silica to precipitate before being injected.

2. Calcium Carbonate Deposition. Calcite deposits most often form in geothermal waters with high carbon dioxide content. For geothermal waters ranging from $230^{\circ}$ to $300^{\circ} \mathrm{C}$ $\left(446^{\circ}\right.$ to $\left.572^{\circ} \mathrm{F}\right)$, the critical concentration of $\mathrm{CO}_{2}$ may be about 0.1 molar, with calcite scaling likely to cause problems at higher $\mathrm{CO}_{2}$ levels. At lower temperatures, carbon dioxide is more soluble and calcite does not precipitate as much.

Calcite deposits commonly occur on or near well screens due to the pressure reduction in the vicinity of the well screen when water is pumped from the well. Because of the reduction in pressure, some carbon dioxide is released from the water, causing calcium carbonate to precipitate. The precipitation of iron and manganese compounds may also be caused by the release of carbon dioxide from ground water.

Certain waters rich in calcium salts often cause hard deposits to build up in low-temperature geothermal wells at the point where the uprising hot water starts to flash into steam. These deposits will reduce the fluid output due to the restriction they form, and may eventually cumpletely clog the well. This problem can be avoided by periodically reaming the well to clear the deposit. However, if calcite builds up too rapidly, it may be necessary to abandon the well. The frequency of reaming depends largely on the fluid yield when the well is clear of deposits, as well as the rate of build up. High-production wells require a large de- 
gree of calcite deposition before they become economically unserviceable. The deposition of calcite is related not only to the calcium but also to the $\mathrm{CO}_{2}$ content of the geothermal fluid.

If permeability is low, calcite deposition may sometimes occur in the rock formation surrounding the well. This is due to flashing before the fluid reaches the well screen. This may be of little importance if disseminated homogeneously, but may cause irreparable decay in withdrawal rates if deposited in a major flow fissure at a specific point.

3. Complex Scales. In sulfate=rich genthermal hrines, a cumplex scale ur silica plus irvul, pulássium, and calciuni sulfates can form. The scale composition depends on the water rontent of the discharge, water romposition, temperatures, and $\mathrm{pH}$. Ábove $60^{\circ} \mathrm{C}\left(140^{\circ} \mathrm{F}\right)$, calcium sulfate becomes less soluble and precipitates. Corrosion of steel casing adds to the complexity of the scale compositions. In acid brines containing hydrogen sulfide, corrosion of the metal casing forms iron sulfide, but since this compound is insoluble, it is deposited as iron scale in the casing. Iron scale has a larger volume than the original metal, and gradually fills the casing, reducing its water carrying capacity. Just as a change in pressure can result in the precipitation of calcium carbonate, so a change in velocity can produce turbulence which leads to the formation of insoluble iron and manganese hydroxides.

4. Bacteria. Bacterial plugging is caused by various genera of iron bacteria which oxidize dissolved iron and manganese, causing them to precipitate. The combination of scale and bacterial growth creates a voluminous material that quickly plugs the aquifer surrounding the well screen. This results in channeling the well production through relatively few openings, which leads to erosion-corrosion and failure of the well screen.

Iron bacteria are generally found in $\operatorname{cool}\left(18^{\circ} \mathrm{C}\right)\left(64^{\circ} \mathrm{F}\right)$, shallnw, aerated ground water containing high concentrations of iron and manganese but low total dissolved solids $(<1,000$ ppm).

Sulfate-reducing bacteria are found in anaerobic sulfate-rich brines. These bacteria reduce sulfate to sulfide. The sulfide combines with hydrogen in the water to become hydrogen sulfide which is corrosive to metal casing. 


\section{WITHORAWAL RATE}

In the development of a geothermal field, wells are drilled into the reservoir. Water or a mixture of water and steam enters the well through a well screen, slotted casing or an open hole. As the water is pumped out, the reduced hydrostatic pressure at the well causes movement of other water toward the well. The rate at which water moves toward the well, and therefore the rate at which water can be withdrawn from the well, is a function of the permeability of the materials from which the water is drawn.

Although permeability may be sufficient in some reservoirs to provide a reliable withdrawal rate, other reservoirs may be too thin or cemented by hydrothermal minerals. In these reservoirs, channel or fissure permeability produced by fracturing must be sought. This is known as secondary permeability.

Self-sealing and a resulting decrease in permeability have been recognized in several liquid-dominated geothermal reservoirs. Typically, quartz. or opaline silica deposited near or at ground level from cooling silica-saturated waters blocks or reduces fluid access to the surface. Quartz deposition is greatest where the temperature decrease is most abrupt, such as at the margins of fields where steep horizontal thermal gradients can be expected.

Permeability may also be reduced by the deposition of clays, zeolites, feldspars, pyrite, and hematite. Where subsurface boiling occurs, calcite deposition further reduces permeability.

Hydrothermal mineral deposition is not always deleterious to permeability. It makes rocks harder and denser, hence more susceptible to fracturing and the creation of secondary permeability.

Some geothermal reservoirs with maximum temperatures below $150^{\circ} \mathrm{C}\left(302^{\circ} \mathrm{F}\right)$ may become more permeable with time because as much as $140 \mathrm{ppm}$ of $\mathrm{SiO}_{2}$ is dissolved during the heating of cold meteoric water of $\mathrm{low} \mathrm{SiO}_{2}$ content. $14 \mathrm{~A}$ temperature of $150^{\circ} \mathrm{C}\left(302^{\circ} \mathrm{F}\right)$ is high enough to increase the porosity of quartz-bearing reservoir rocks, but may not be high enough to be offset by hydrated alteration minerals which tend to decrease porosity. 
Some geothermal reservoirs do not have adequate volume, temperature, or permeability to maintain an adequate well yield. Well yield is the volume of water per unit of time withdrawn from a well, either by pumping or by free flow. It is commonly measured in gallons per minute or liters per second.

The practical sustained yield of a well is the rate at which ground water can be continuously withdrawn without lowering water levels to critical stages, exceeding recharge, or causing undesirable changes in water quality and temperature. The sustained yield is determined by the average annual recharge rate. If withdrawal exceeds recharge there may be land subsidence in areas with interbedded sand and clay. This will place additional pressure on the casing and may cause sudden collapse.

Computations of the practical sustained yield of a geothermal reservoir require a complete hydrogeologic systems analysis using detailed maps. However, generalized maps of yield can be made using yield data from existing wells and basic geologic data. Such maps can be used to estimate well yield at a certain locality within a specified range.

Generally, the quantity recovered from the ent ire reservoir for use will be far less than the sustained yield due to the practical limitations of recovery techniques. Doubling the diameter of a well will not double its yield. For example, if a $152-\mathrm{mm}(6-\mathrm{in})$ well yields $6.31 \mathrm{l} / \mathrm{s}(100$ gpm) with a certain drawdown (drop in water level), a 305-mm $(12-i n)$ well at the same location with the salle drawdown will yield only $6.94 \mathrm{l} / \mathrm{s}$ (110 gpm).21

The yield of a well per unit of drawdown is called its specific capacity. For confined aquifers or geothermal reservoirs with cap rocks, the specific capacity is constant at any pumping rate as long as the water level in the well does not go below the confining layer. For a well in a water table aquifer or an unconfined hot water geothermal reservoir, the part of the reservoir within the cone of depression is lewatered during puimping. I hus, when drawdown doublrs, the well yield is less thall duble since the volume of water available is not twice as much. In other words, the specific capacity decreases with increasing drawdown. Optimum well design and operating characteristics are obtained when the product of yield and specific capacity is largest. This usually uccurs at about 67 percent drawdown.25 
The feasible yield from a geothermal-well or well field for low-temperature applications is determined from an economic analysis involving the amount of water and heat needed, the temperature of the water, the specific capacity of the wells, the cost of power, and the cost of wells and pumps.

The total water needs for a proposed geothermal development will largely depend on the reservoir temperature and intended use of the geothermal water. If the use is. space heating, the amount of water needed will be low. For a temperature between $55^{\circ}$ to $80^{\circ} \mathrm{C}\left(131^{\circ}\right.$. to $\left.176^{\circ} \mathrm{F}\right)$ and a flow rate of $27.75 \mathrm{l} / \mathrm{s}(440 \mathrm{gpm})$ per well, a thermal output of 5 to $8 \mathrm{MW}$ above ambient temperature can be produced. However, large amounts of water will be needed if the water is used for industrial purposes. A good product ive steam well should produce at least $5 \mathrm{Kg} / \mathrm{sec}$ (20 tons $/ \mathrm{hr}$ ). 26 Many wells produce much more. The maintenance of such high flow rates requires a high degree of permeability in the reservoir, with porosity playing only a secondary part. Any permeable rock can serve as a good geothermal reservoir. 


\section{WATER DEPTH}

A direct relationship does not necessarily exist between the water-bearing capacity of a rock and the depth at which it is found. A very dense granite may be found at the land surface, while a porous sandstone may lie several thousand meters underground. However, as a general rule, porosity and permeability decrease with depth since the voids and interstices in the rock close under the weight of overlying rocks. Low-temperature geothermal water has been found at depths exceeding 4,260 meters $(14,000 \mathrm{ft})$. Depth to water is the primary factor in estimating well drilling and construction costs. Wells deeper than 610 meters $(2,000 \mathrm{ft})$ require oll well drilling equipment which is considerably more expensive than water well drilling equipment. Other factors include type of drilling method used, rock type, season of the year, diameter of the well, amount of casing, and type of material used in constructing the well. Since temperature and corrosiveness of geothermal brines generally become more severe with depth, maintenance and repair costs also increase with depth. The cost of pumping depends on the depth to water and other factors discussed in Chapter 2 of Volume I. Thus, the deeper the water, the greater the drilling, maintenance, and pumping costs. This expense may be justified by the greater value of heat at higher water temperatures in deep wells. Deep waters which circulate along faults in regions of elevated heat flow can best explain the warm springs(some with temperatures up to $40^{\circ} \mathrm{C}$ $\left(104^{\circ} \mathrm{F}\right)$ along the Appalachian Mountains and the hot springs of the Great Basin. Deep basins filled with sedimentary rocks of high porosity and permeabilit.y can achieve temperatures of $150^{\circ} \mathrm{C}\left(302^{\circ} \mathrm{F}\right)$ or greater at extractable depths provided that the geothermal gradient and heat flow are sufficient.

A shallow, ambient-temperature $\left(4^{\circ}\right.$ to $\left.26^{\circ} \mathrm{C}\right)\left(39^{\circ}\right.$ to $79^{\circ} \mathrm{F}$ ) aquifer may be enhanced by using a ground-water geothermal heat pump to raise the water temperature. Downhole heat exchangers (DHE) have been used at depths from 10 to over 140 meters ( 33 to $460 . \mathrm{ft}$ ). 27 


\section{WATER TEMPERATURE}

Ambient ground-water temperatures vary throughout the United States from $2^{\circ} \mathrm{C}\left(36^{\circ} \mathrm{F}\right)$ in Alaska to $26^{\circ} \mathrm{C}\left(79^{\circ} \mathrm{F}\right)$ in southern Florida. Generally, these temperatures exceed the mean annual air temperature by 1 or $2^{\circ} \mathrm{C}\left(1.8^{\circ}\right.$ or $\left.3.6^{\circ} \mathrm{F}\right)$. Figure 1 shows the distribution of shallow ground-water temperatures in the contiguous United States. This map is similar to a map of mean annual air temperatures, but is more accurate since it is based on temperature measurements in several thousand wells 15 to $46 \mathrm{~m}$ (50 to $150 \mathrm{ft}$ ) deep. Dashed contours were used in areas where there were less than four wells per county.28 At shallow depths, ground-water temperatures can vary as much as $5^{\circ}$ to $8^{\circ} \mathrm{C}$ annually. This variation disappears at depths over 9 to 18 $\mathrm{m}$ (30 to $60 \mathrm{ft}$ ) depending on rock type, climate, and distance to recharge area.

Ground-water temperature tends to increase $1^{\circ} \mathrm{C}\left(1.8^{\circ} \mathrm{F}\right)$ for each $30 \mathrm{~m}$ (100 ft) increments below a depth of $18 \mathrm{~m}$ $(60 \mathrm{ft})$. This increase is referred to as the normal geothermal gradient and is caused by the movement of heat from the earth's interior to the surface. The geothermal gradient can be as 1 ow as $10^{\circ} \mathrm{C}$ per $\mathrm{km}\left(29^{\circ} \mathrm{F} / \mathrm{mi}\right)$ or as steep as $250^{\circ} \mathrm{C}$ per $\mathrm{km}\left(724^{\circ} \mathrm{F} / \mathrm{mi}\right)$. The range of temperature gradients for typical nonthermal areas is $25^{\circ}$ to $30^{\circ} \mathrm{C}$ per $\mathrm{km}$ $\left(72-86^{\circ} \mathrm{F} / \mathrm{mi}\right)$. Some areas of the United States have anomalous geothermal gradients due to volcanic activity, subduction zones, high concentrations of radioactive elements in the bedrock, or deep circulating ground water. These geothermal gradients are delineated in Figure 2. This map is based on data from oil and gas well temperature records, and from recent estimates for the Atlantic Coastal Plain. Blank areas represent areas where data is lacking 29 .

In general, the average heat content of rocks is considerably higher in the western United States than in the East. This explains why most wet steam and hot water reservoirs occur in the West (Figure 3 ). Temperature gradients are higher in the Atlantic and Gulf Coastal Plains than in other eastern regions because the high-porosity sediments of the coastal plains have low thermal conductivities. Also, along the Atlantic Coast there are numerous radiogenic plutons (large intrusions of igneous rock) which result in high, local temperature gradients. 


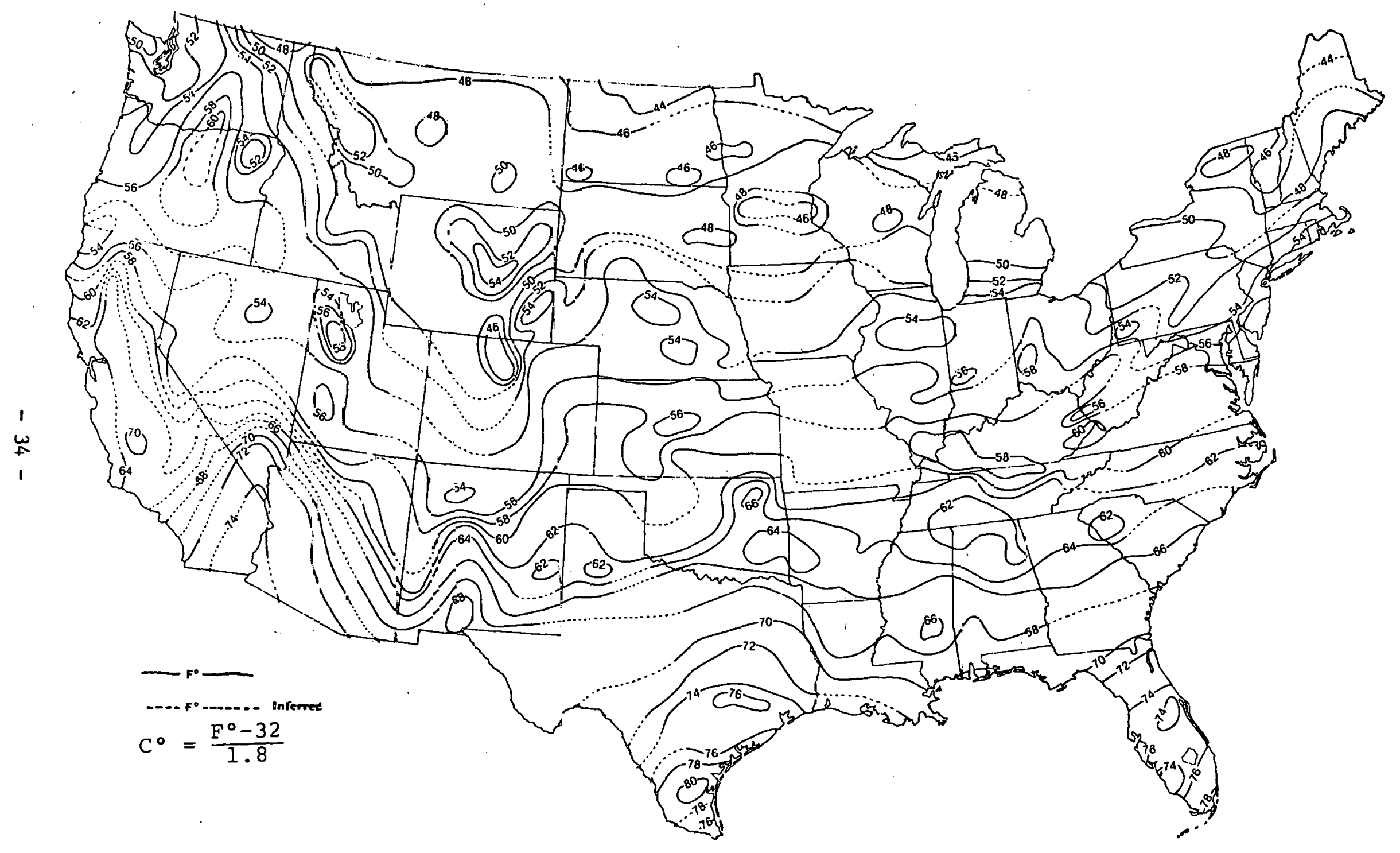

Figure 1. Ground hater Temperatures in Wells Ranging from 50' to $150^{\prime}$ in Depth. 


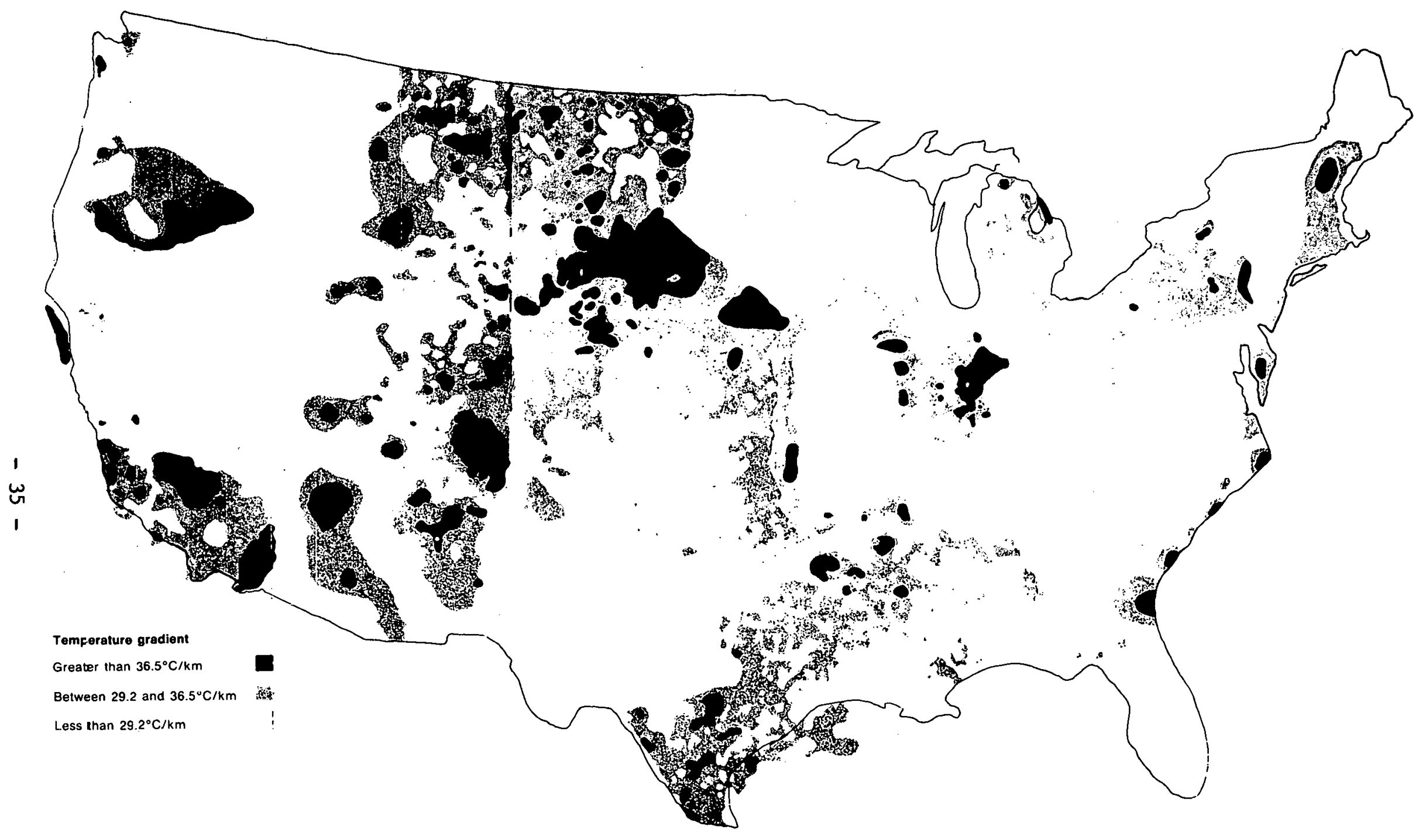

Technology Review, Febiuary, 197961

Figure 2 . 


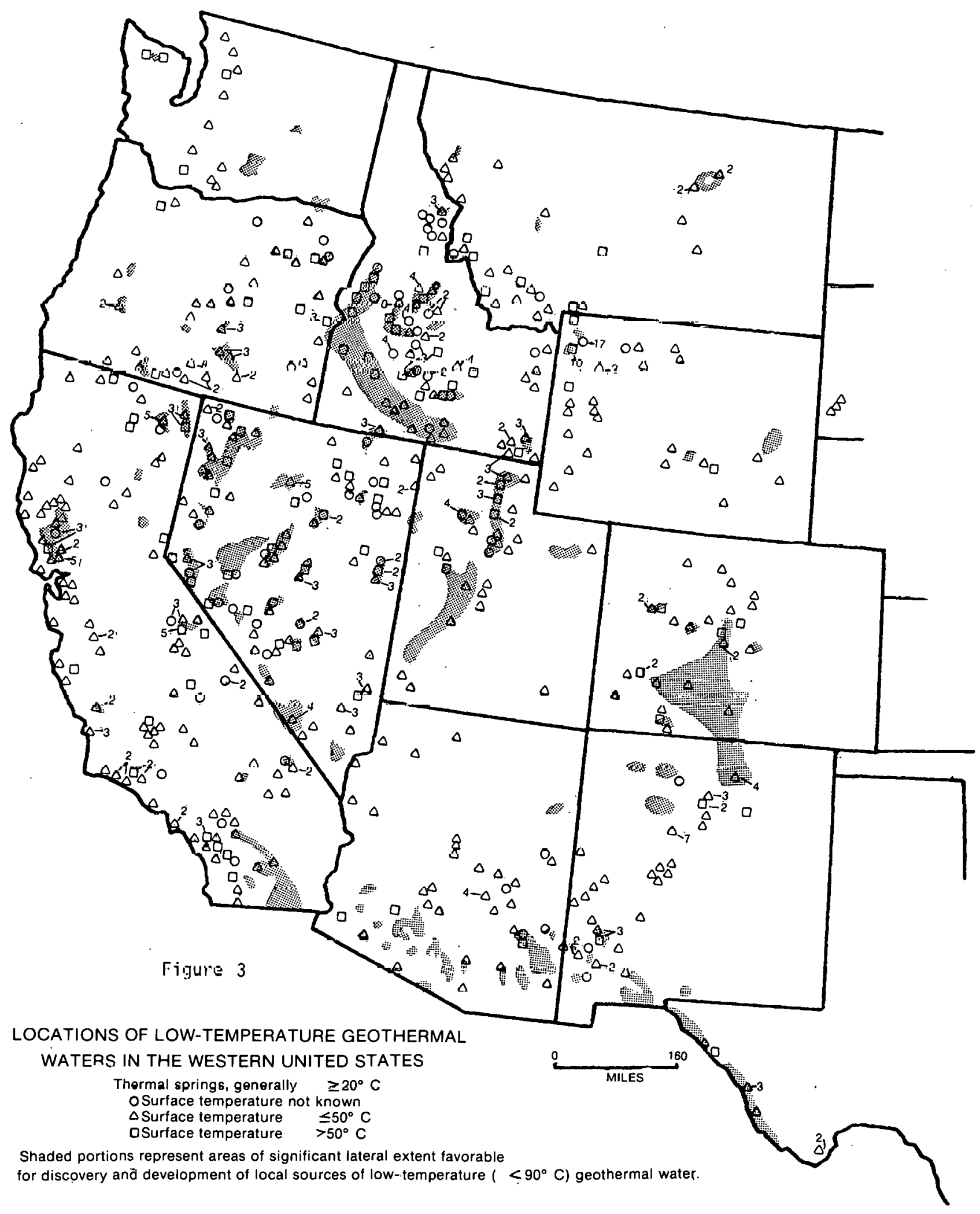

Based on Map 1 of U.S. Geological Survey circular 790 "Assessment of Geothermal Resources of the United States-1978" 


\section{BASIC WELL DESIGNS}

For any type of ground water environment, only one or two basic well designs are appropriate. All of these basic designs can be varied slightly to fit any situation, so an almost infinite variety of well designs are possible. In 1966, NWWA assisted the American Water Works Association in preparing a standard for deep wells which has been published as AWWA Standard A-100. In the text of this standard, 11 categories classify the universe of possible well designs. Each category deals with a particular type of subsurface geology. Figure 4 illustrates the 11 basic well designs.

\section{A. Unconsolidated Formations}

Wells in unconsolidated formations (sands and gravels) are cased with durable tubular material through the soil and loose, nonproduct ive formations. At the levels of the producing zone(s), the well is completed with a screen or filter designed so that ground water can be extracted at maximum efficiency without fine formation particles migrating into the well bore. AWWA Standard A-100 lists five types of unconsolidated formation wells. (The descriptions which follow are condensed from the text of the Standard).

$\frac{\text { Type } 1 \text { - Unconsol idated Formations, Caving Material only }}{\text { Te casing may be sufficient if the formations are of a }}$ single casing may be sufficient if the formations are of a
caving nature for the full depth of a well, and the well is finished with a screen at the bottom. In this type of construction, the screen is sealed to the well casing by means of a packer and may be replaced if necessary.

Type 2 - Unconsolidated Formations, Caving Material Only Additional protection against corrosion and pollution (beyond that afforded by Type 1) may be provided by installing an outer casing to a sufficient depth and filling the annular space between the casings with cement grout. The screen is independent of the casing to which it is sealed by a packer. This type of construction will permit replacement of the screen. Outer casing may not be required if the conventional rotary or reverse-rotary method of construction is used, but the diameter of the hole should be 76 to $102 \mathrm{~mm}$ ( 3 to $4 \mathrm{in}$ ) greater than that of the couplings of the protective casing. 


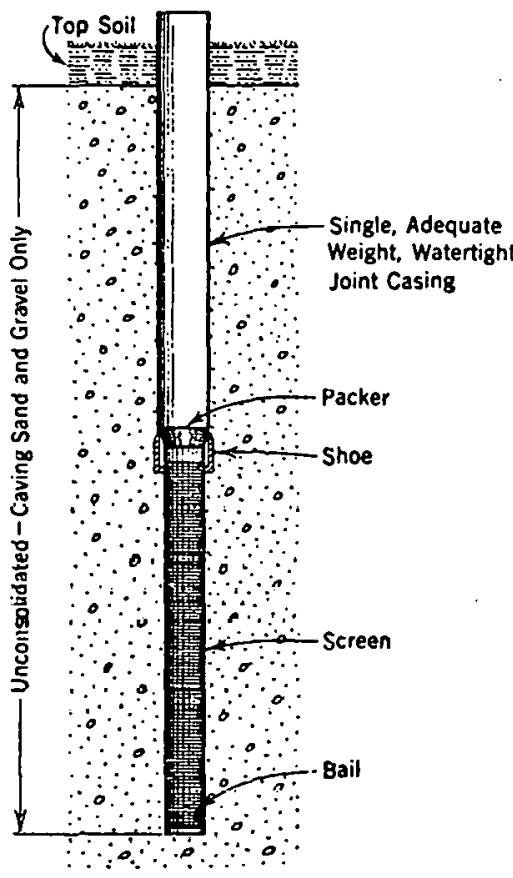

TYPE 1

UNCONSOLIOATED FORMATION

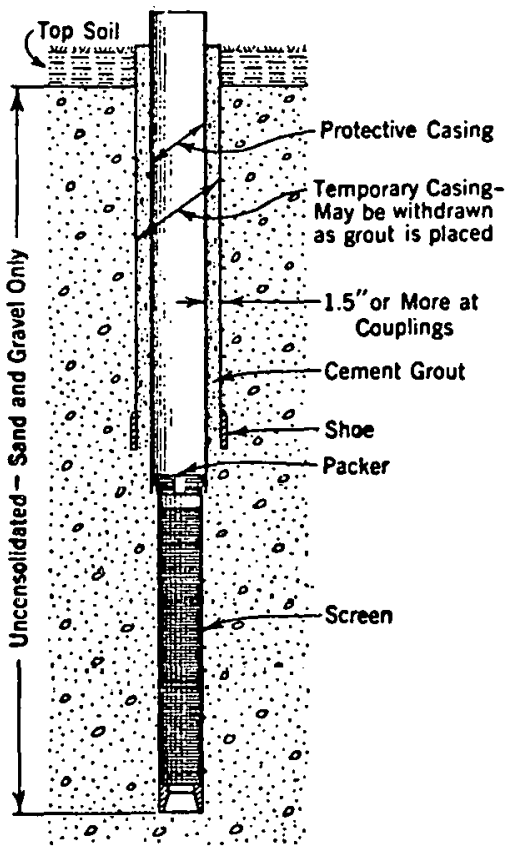

TYPE 2

UNCONSOLIDATED FORMATION

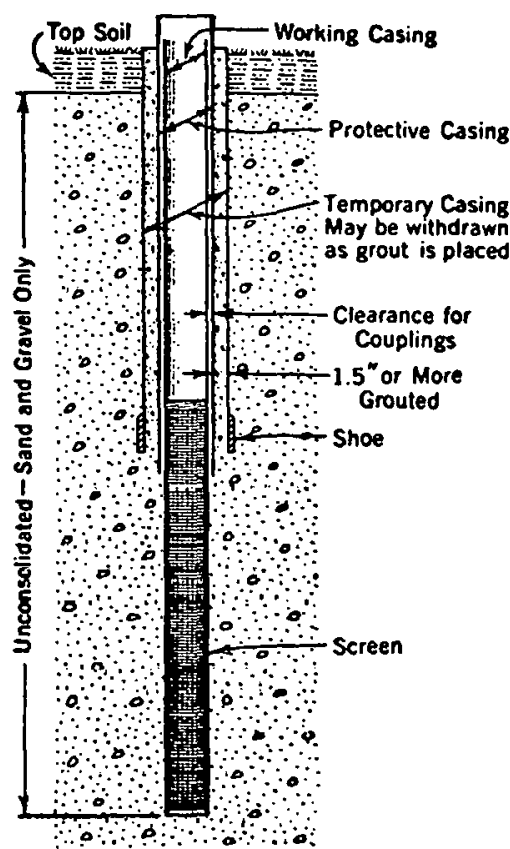

TYPE 3

UNCONSOLIOATEO FORMATION

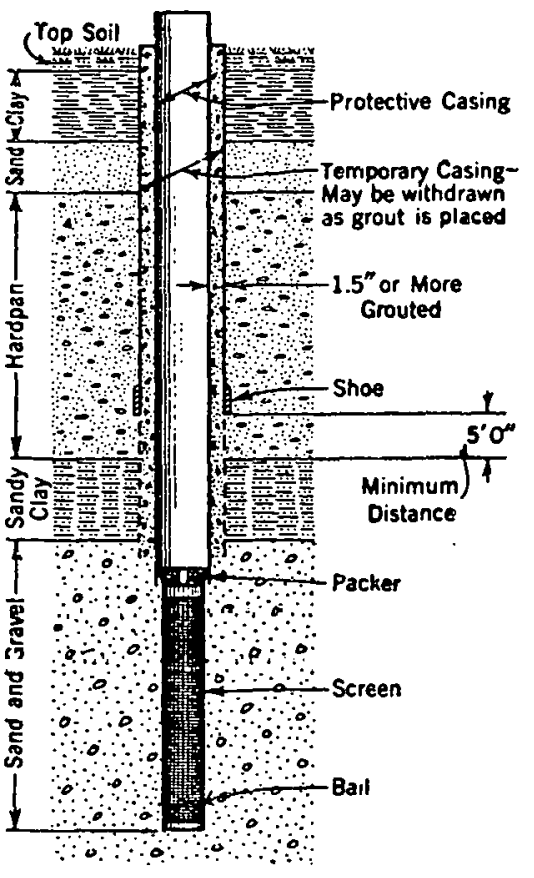

TYPE 4

UNCONSOLIDATED FORMATION
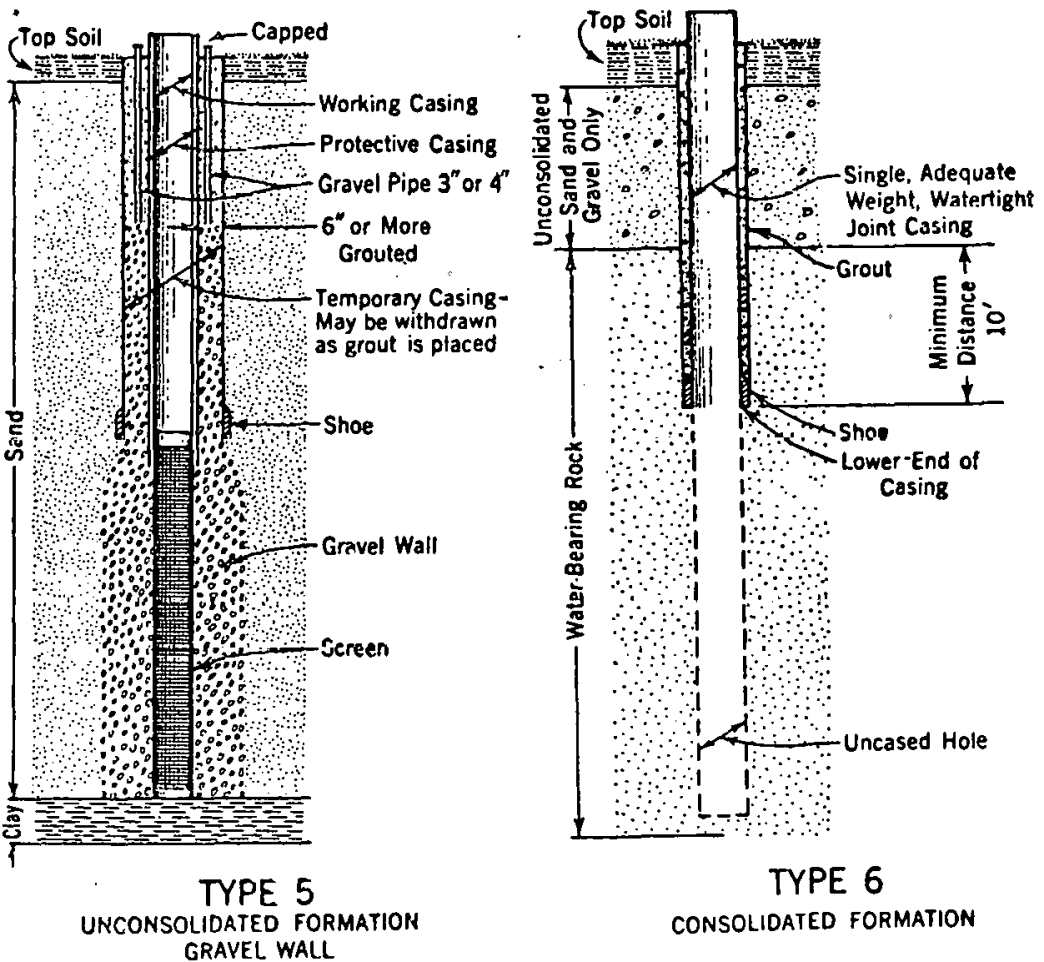

CONSOLIDATED FORMATION

Figure 4. 


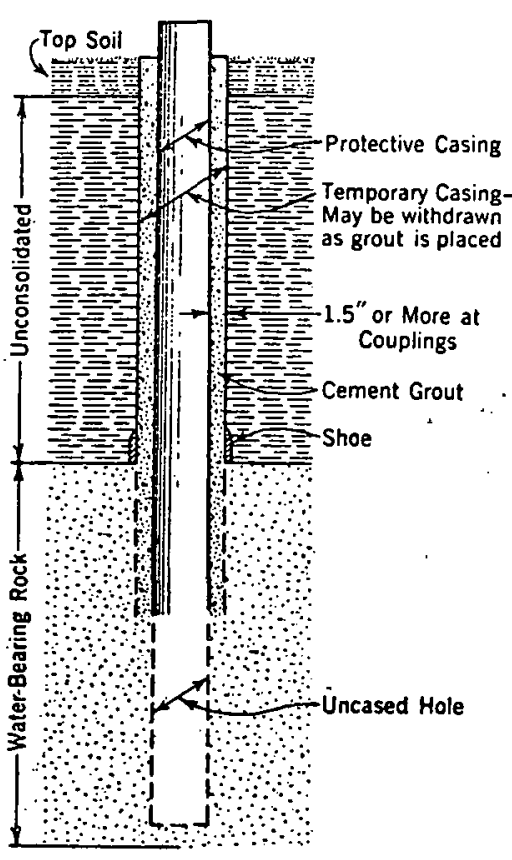

TYPE 7

CONSOLIDATED FORMATION

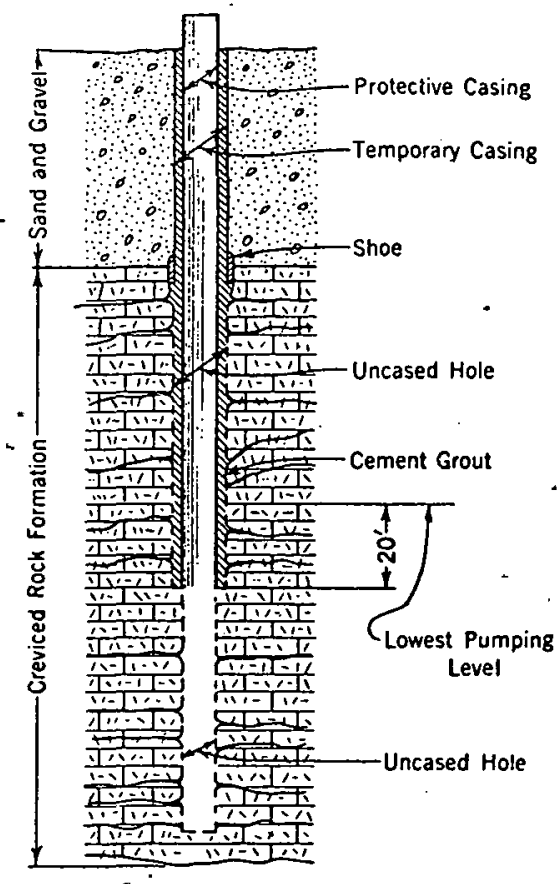

TYPE 8

CONSOLIDATED FORMATION

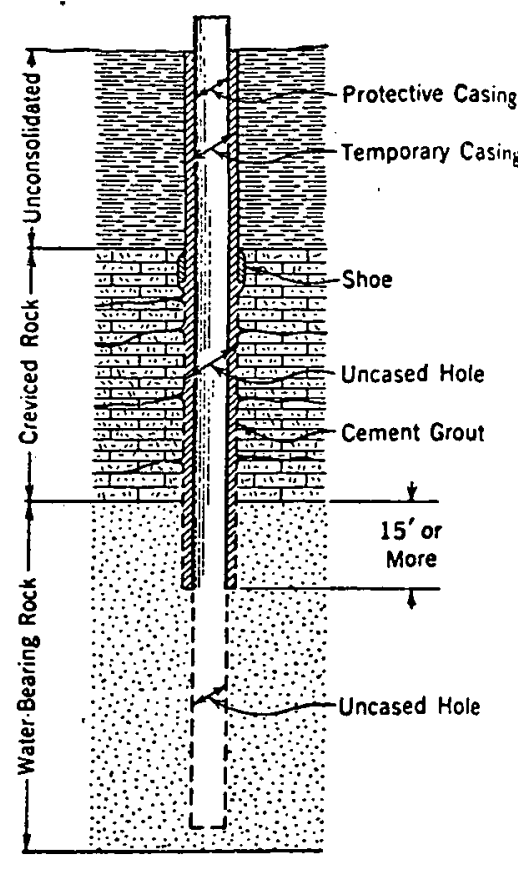

TYPE 9

CONSOLIOATED FORMATION

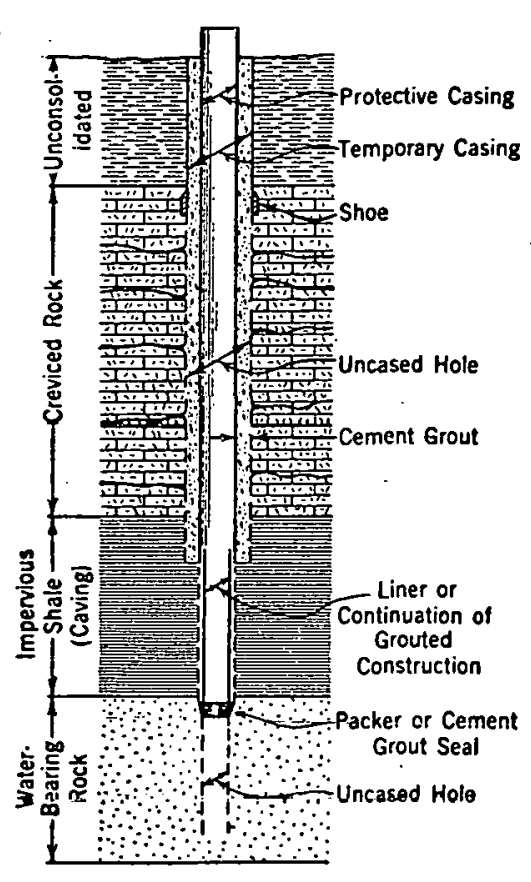

TYPE 10

CONSOLIDATED FORMATION

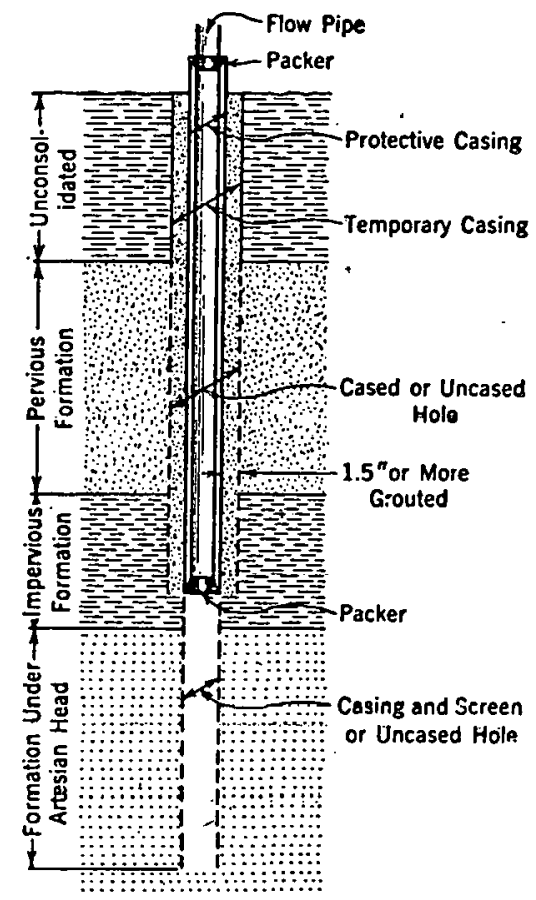

TYPE 11

ARTESIAN CONDITION

Figure 4. (Cont' ',) 
Type 3 - Unconsolidated Formation, Sand and Gravel Only To provide grout protection similar to Type 2 and also to permit removal and replacement of the screen by means of the casing to which it is attached by threaded or welded joint, the grout should be placed between two exterior casings. In such construction, the intermediate casing should be considered the protective casing. If the well is constructed by the conventional rotary or reverse-rotary method, all or part of the outer casing can be eliminated.

Type 4 - Unconsolidated Formation, Including Clay, Hardpan, or Shale when the water-bearing formation lies below. clay, hardpan, shale, or other non=caving material, the grouted type of construction should be adopted to ensure sealing of lie arimulai space fumled durirly drilliny. If a temporary outer casing is used in such formations, it should be withdrawn completely or enough so as to place the lower end within and at least $1.5 \mathrm{~m}$ ( $5 \mathrm{ft}$ ) above the bottom of the lowest stable unconsolidated formation. The grout seal should extend to the bottom of the clay or other non-caving formation, and should be placed as the casing is withdrawn. If the conventional rotary or reverse-rotary method of construction is used, no outer casing may be required.

Type 5 - Unconsolidated Formation, Gravel Wall Wells This type of well may be constructed similarly to Type 3 except the diameter of outer casing and the width of annular space are usually greater. The annular space is initially used to place the gravel wall. After the gravel is placed and the development of the well is completed, pipes are installed to permit the admission of more gravel through that part of the annular space which will be filled with grout. The outer casing may be withdrawn as the grout is placed.

B. Consolidated Formations

Wells constructed in consolidated formations are typically cased only through overburden and nonproducing zones; the producing zone is usually completed as an open hole. The AWWA Standard A-100 categorizes such wells into six types:

Type 6 - Consolidated Formations Underlying Sand and Gravel The single-cased type of well penetrating rock formations is frequently used but is not recominended. It should never be used in creviced formation or with clay, 
hardpan, or other relatively stable unconsolidated materials. It is very difficult to get a tight joint between the casing and the rock, and pollution or sand may enter the well as a result. Type 7 construction is preferable.

Type 7 - Consolidated Formation, Underlying Clay or Hardpan For non-caving formations and particularly where protection against corrosion is essential, grouted casing construction is recommended.

Type 8-Consolidated Formation, Channelized, Creviced, or shattered Rock Formations that are channeled, creviced, or fractured may yield unsafe water. Where there is an adequate cover of unconsolidated material and existing ungrouted wells tap only the upper portion of the formation, protection may be obtained if the supply is developed by extending watertight construction of the well to a depth greater than that of the deepest existing wells of questionable construction. The watertight construction should extend to a point at least $6.1 \mathrm{~m}(20 \mathrm{ft})$ bel ow the lowest water level.

Type 9 - Consolidated Formation, Water-Bearing Rock Below Creviced Rock where an adequate water supply of suitable quality can be obtained from a rock formation overlain by a creviced rock formation, the creviced formation should be completely cased off with the watertight construction extending into the water-bearing rock formation.

Type 10 - Consolidated Formation, Impervious Formation Underlying Creviced Formation where a formation known to be impervious and continuous over a large area underlies a creviced or contaminated water formation and overlies the water-bearing formation, termination of the protective casing in the top of the impervious formation is an acceptable construction. Such protective casing should be surrounded with cement grout. If the impervious formation is of a caving nature, the installation of a liner through it and into the underlying stable formation will be necessary.

Type 11 - Artesian Conditions, Possibly Producing Flowing Wells When a well projects into an artesian water formation, the well should be constructed so that it conserves the supply and head by preventing water loss into 
the overlying porous formations under less head and leakage to the surface around the casing pipe. Also, the construction should be such that if a flow develops, it will be controlled. Such artesian wells may be properly developed in either consolidated or unconsolidated formations.

In constructing such wells the initial drilling operations should extend into, but not through, the impervious formation, confining the water under artesian head. Where the nature of the impervious confining bed permits erosion by the flowing water, a casing extending into the artesian aquifer is essential.

\section{TIIE IYYOROGLOLOGIC PROVINCES}

Despite the effects of highly localized genlngic. varialiuns un well design, basle sillilartties in geology over larye areas still have significant influence. These similarities make it possible to discuss "typical wells" for many areas, both in terms of cost and design. Various classifications have been proposed over the years to describe common regional characteristics of U.S. hydrogeology. In the 1920 's, Dr. O.E. Me inzer of the U.S. Geological Survey developed a system of 21 ground-water provinces based on aquifer types and age of water-bearing formations. This system was simplified by Harold E. Thomas in the early 1950's, resulting in a 10-province classification 30. 'Although Thornas' scheme gives little consideration to geologic age, his system provides a reliable framework for comparison and conmentary about drilling and ground-water development practices across the country.

The 10-province scheme has been extrenely useful in previous studies undertaken by the NWWA Research Facility. Thonas' scheme is used in this study as a basis for discussing regional variations in drilling practices and costs. Figure 5 outlines the 10 regions in the conteminous United States. The most basic characteristics of these regions are suminarized as follows.

The Glaciated Appalachian province is an area of anclent hard rock overlain by irregular deposits of glacial inaterial. Valleys are commonly filled with sand and gravel outwash. Small water wells in this area are completed either in unconsolidated surficial deposits or in bedrock; however, large industrial or municipal wells are generally 


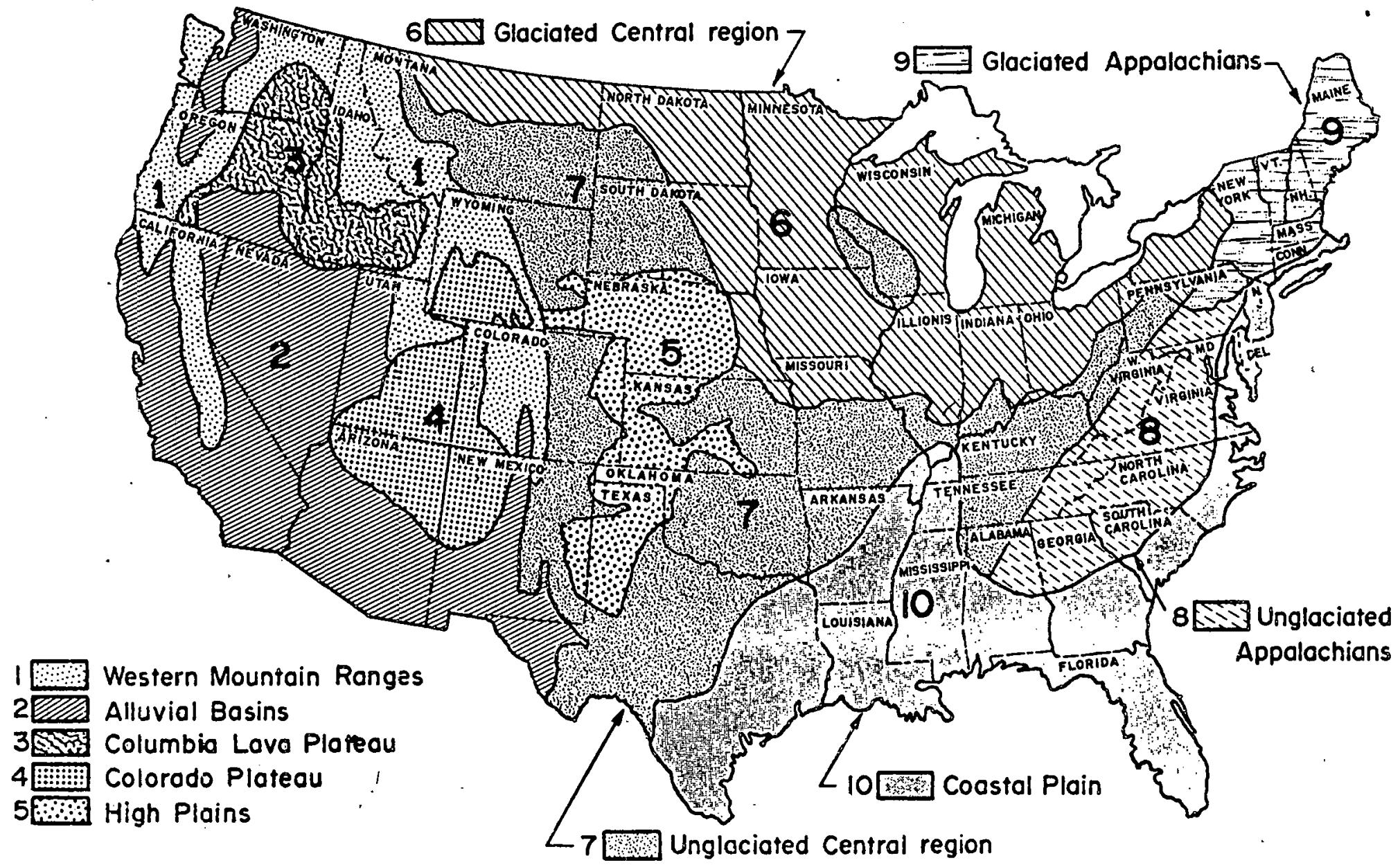

Figure 5. Ten major ground-water regions of the United States, excepting Alaska and Hawaii. (After Thomas and McGuinness) 
confined to more productive watercourse or outwash aquifers. Mud rotary or cable tool methods are used in the unconsolidated formations, while air hammer or cable tool rigs are used in hard bedrock. On the whole, well construction is neither easy nor difficult in this region.

The High Plains ground water province presents a totally different well construction situation. The High Plains is an area of thick unconsolidated aquifers formed primarily by weathered material washed down from adjacent highlands. With the exception of a few small scattered boulders, conditions are practically ideal for mud rotary or reverse rotary drilling; the sandy or silty formations are easily penetrated, yet the clay in the formations allows borehole stability to be easily maintained. Water wells in this area can be completed quickly and cheaply. The High Plains is the only region where the use of thermoplastic casing for small to medium-sized wells is the norim rather than the exception. Plastic casing is receiving increased acceptance across the United States in conjunction with rotary drilled wells; however, steel casing still predominates over most of the nation.

The Unglaciated Appalachian region is a marked contrast to the High Plains. In this area in the southeastern U.S., water wells are completed either in dense, nonporous rock or in relatively thin overburden. Domestic well yields of less than $.63 \mathrm{l} / \mathrm{s}(10 \mathrm{gpm})$ are relatively easy to obtain; however, finding the proper location for a high-capacity municipal or industrial well can be a problem. Although much drilling in this area is in hard rock, these formations generally pose few problems for cable tool or downhole hammer rigs.

The Arid Alluvial Basins Province encompasses nearly all of Nevada and parts of adjacent states. The extensive unconsolidated formations in this region have basically the same origin as those of the High Plains (material which was washed down from surrounding highlands over a period of many years). The region is an area of low precipitation and sparse population. Ground water is sometimes available only at great depths, and boulder flelds, thick clay beds, and quicksand occasionally make well construction difficult.

The Atlantic and Gulf Coastal Plain Province is blessed with abundant supplies of ground water found in various consolidated and unconsolidated formations characteristic of 
continental margins. Water quality poses some problems in the area, since heavy pumpage over the years has encouraged localized saline water intrusion. Wells in this extensive region range anywhere from tens to hundreds of meters deep. Drilling is fairly easy in this area; since some aquifers have such high yields, $51 \mathrm{~mm}$ ( 2 in). diameter wells are frequently adequate for domestic supplies. $152 \mathrm{~mm}$ (6 in) and $203 \mathrm{~mm}$ ( $8 \mathrm{in}$ ) wells in this area have a fairly high capacity, and are often suitable for commercial and small public water supplies.

The Columbia Lava Plateau in Washington, Oregon, and Idaho is the result of the region's volcanic activity about 25 million years ago. The basaltic lavas of the province are fractured and jointed in many places, yielding plentiful ground-water supplies. Glacial activity in the Pacific Northwest also left behind a few significant outwash aquifers. Cable tool and air drilling methods predominate here as in other hard rock areas of the country.

The Western Mountain Province traces a huge arc from Colorado to the northwest and back down through California. Two types of aquifers are found here. Unconsolidated alluvial aquifers occur in the valleys scattered throughout the region, frequently yielding large quantities of water. Hard rock aquifers (basalt, andesite, and granite) usually have much smaller yields. Mud rotary methods are the most common techniques for drilling alluvial aquifers, and air hammer techniques are the norm for hard rock.

The Colorado Plateau Region is a somewhat desolate area in which the driller population, and population in general, is sparse. This region is underlain largely by sedimentary formations (shales, sandstones, and carbonate rocks). The series of individual plateaus which comprise the region is marked by gullies and gorges, the Grand Canyon being the most outstanding example.

Usable ground-water supplies can be found both in alluvial watercourse aquifers or by drilling deep into the sedimentary formations. Boulders and caving sands are sometimes encountered in well construction, but drilling is generally not terribly difficult.

The final two ground-water provinces, the Glaciated and Unglaciated Central Regions, are vast areas sprawling across the middle portion of the nation. A variety of drilling

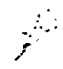


conditions are encountered in these provinces. The entire area is underlain by sedimentary formations, most of which yield usable quantities of ground water. High-yield wells are frequently constructed in river valleys or in areas

filled by glacial outwash. In the Glaciated Province, a blanket of glacial drift covers almost all of the region and can be a productive ground-water source in many areas. The variable geology in these areas demands more versatile drilling and it is not uncommon for Central Region contractors to own two types of rigs in order to cope with the variety of situations they encounter. 


\section{APPENDIX C PROPERTIES OF METALLIC AND NONMETALLIC MATER IALS}

A comparision of the properties of metallic and nonmetallic materials will show significant differences between metals and nonmetals in general, between various types of metals and nonmetals, and between various grades of a specific material.

The most economical material for a given set of geothermal conditions may be a metal, a nonmetal, or a combination of both, depending on what properties are needed. Low carbon steel may prove satisfactory when conditions demand high strength but not high corrosion resistance. Fiberglass-reinforced plastic may be more cost effective for low-temperature corrosive conditions.

The properties of a material will determine the range of conditions in which it is serviceable. Within this range, there will be a subrange in which it may be either more or equally economical than a base material such as low carbon steel. Table 1 lists important properties of metallic and nonmetallic materials that can be used in low-temperature geothermal well construction.

A rating system was used to compare different nonmetallic materials. The most favorable value of a property was given a rating of 1 while the least favorable value was given a rating of 0 . Certain properties are more important than others and were weighted accordingly. The ratings for specific gravity and temperature limit were multiplied by 3 while the ratings of tensile properties, impact strength and water absorption were doubled. Thus the rating for a given material is the sum of the ratings for each property of that material divided by the number of properties examined.

All the thermoplasticswere rated good to very good with polypropylene and ABS achieving the highest ratings. Of the thermosets, epoxy and polyester have excellent properties. Polymer concrete has the highest rating for the miscel laneous materials.

\section{SPECIFIC GRAVITY}

Specific gravity is the ratio of the mass of a body to the mass of an equal volume of water at a specified temperature, us 1 ally $4^{\circ} \mathrm{C}\left(39^{\circ} \mathrm{F}\right)$ at normal atmospheric pressure. 
TAB_E 1 PHYSICAL PROPERTIES OF METALLIC ANN NONMETALLIC, WELL IONSTFIICTION MATERIALS

$$
\text { Rating }
$$

4-0 poor

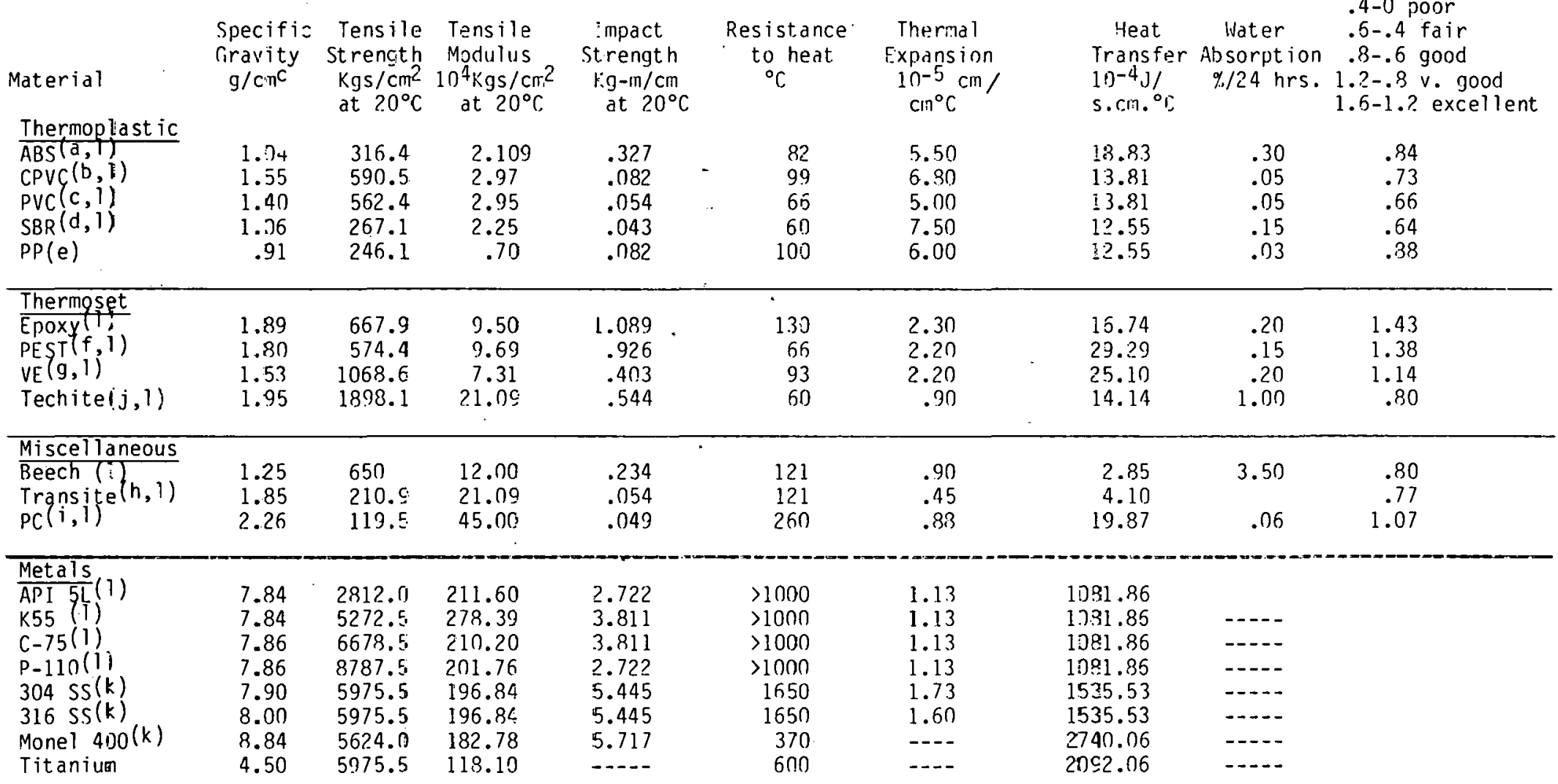

Heat Water

$.5-.4$ fair

a) Polymerized acrylonitrile; butadiene and styrene moncmers

b) Chlorinated polyvinul chloride

c) Polyvinyl chloride

d) Styrene jut adiene copolymer resin

e) Polypropylene

f) Polyzster

g) Vinylester

h) Trademark of Johns-Manville for asbesios celient

i) Polymer Conciete

j) Trade name of Amoco Reinforcad Plastics Co. for reinzorced plastic iortar (RPM)

k) Ilsed predominantlly for well screens

1) Can be used for well casing 


\section{A. Metals}

The specific gravity of a metal is a function of both the type and amount of elements composing it. The values of specific gravities for metals that can be used for low-temperature geothermal wells range from a low of 4.5 for Titanium to a high of 8.84 for Monel. Although aluminum has a specific gravity of 2.7 , its weak mechanical properties and low corrosion resistance exclude it from consideration.

\section{B. Plastics}

Plastics are very lightweight and have a specific gravity about one-seventh that of steel. Specific gravities of thermoplastics listed in Table 1 range from a low of slightly under 1.0 for PP to a high of 1.89 for epoxy. Reinforced thermoset resins have specific gravities that vary over a wide range due to variations in the type and amount of filler. A cotton-reinforced phenolic plastic can have a value as low as 1.3 while a glass-reinforced polyester has a value of 2.1. The light weight of plastic well casing facilitates field handling, transportation, and storage. Also, it gives them a higher strength-to-weight ratio as compared with steel.

C. O.ther Nonmetallic Materials

Specific gravity for asbestos-cement ranges in value from 1.6 to 2.1. Woods range from a low of .13 for balsa to a high of 1.2 for ebony; however, polymer-impregnated beech with a specific gravity of 1.25 should be used for geothermal well casing and screens. Polymer concrete weight varies with aggregate composition and monomer mixture. With a 90:10 ratio of sand to portland cement and a $12 \mathrm{wt} \%$ polymer loading, the specific gravity would be 2.26 .

\section{MECHANICAL STRENGTII PROPLRTIES}

Casing must be strong enough to withstand the forces imposed on it during installation. After installation, various forces continue to affect the casing due to the settlement and shifting of the formation. The well screen must be strong enough to withstand collapse of the surrounding formation and the pressures of well development or rehabilitation. In cases where the screen is driven into the formation, the screen must be able to resist the compressive or tensile stresses placed on it. 


\section{A. Tensile Properties}

Tensile properties include the tensile modulus or modulus of elasticity, yield stress, elongation beyond yield, tensile strength, and energy absorption. During casing installation, tensile stresses occur due to the weight of the casing pipe. If the hole is not straight, increased tensile stresses are created at the outside of the bend. In addition, earth movements during consolidation and well development can cause unavoidable bends in the hole for short or long periods of time which increase tensile stresses. Although these stresses cannot be calculated, experience has shown that a design factor of 5:1 over the theoretical casing and screen weight is adequate. If the well is abandoned and the casing recovered, extremely hiyh tensile stresses will devclop duc to the deadweight of the casing pipe and the friction between the casing and soil.

\section{B. Pipe Stiffness}

This property, which is the ratio of the load per unit length to resultant radial deflection of a casing under parallel plate loading, helps determine the probability of casing deformation during installation or well failure caused by an event such as a borehole cave-in. It may be estimated using the following equation:

$$
\text { P.S. }=\frac{F}{\Delta y}=\frac{4.474 E}{(\overline{D R}-1)^{3}} \quad \text { EQ. } 1
$$

Where F.S. pipe stiffncss, $\mathrm{kg} / \mathrm{cm} / \mathrm{cm}$

$$
\begin{aligned}
\Gamma= & \text { parallcl platc load per unft plpe } \\
& \text { length, } \mathrm{Kg} / \mathrm{cm} \\
\Delta y= & \text { radial deflection, } \mathrm{cm} \\
D R= & \text { ratio of average outside diameter to } \\
& \text { minimum wall thickness } \\
E= & \text { tensile modulus, } \mathrm{Kg} / \mathrm{cm}^{2}
\end{aligned}
$$

Note that pipe stiffness is proportional to the cube of the wall thickness. Thus a greater stiffness can be obtained simply by incorporating more of a particular material into the wall of the casing. Pipe sliffness can be quickly estimated using a pipe stiffness constant. (Kps) for a specified standard dimension ratio (SDR). Equation 1 is simplified to: P.S. $=E(K p s)$ A graph of Kps versus SDR is presented in Figure 1. 


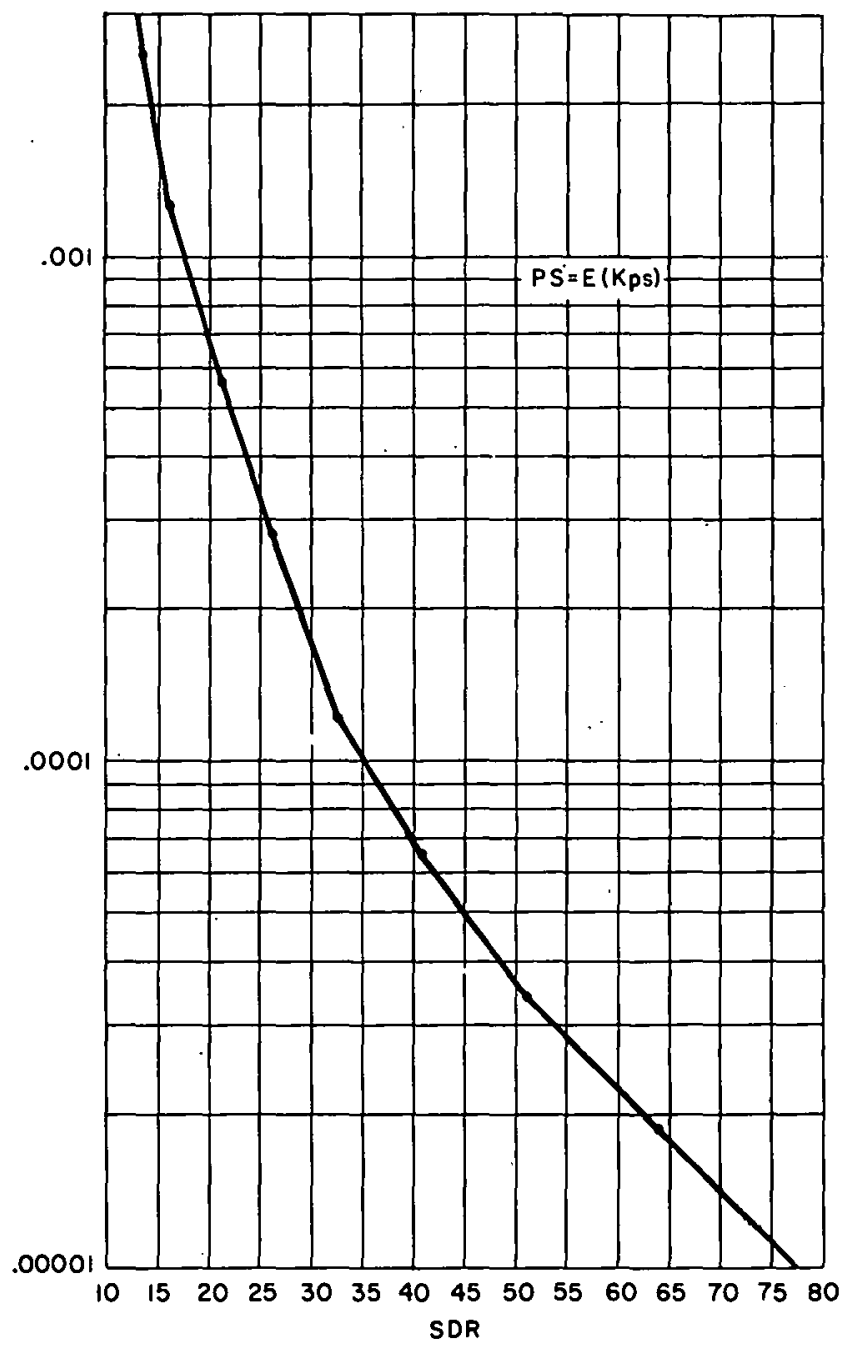

Figure 1. Pipe Stiffness Constant (Kps) vs. Standard Dimension Ratio (SDR) 


\section{Point Loading}

A point load could be exerted on the well casing in many ways. For example, a borehole drilled through a boulder field seldom has smooth walls; rather, pieces of rock are embedded in the surrounding soil. When these rock particles come in contact with the well casing, a point loading situation can develop. This type of localized load is quite different from a uniform load and can impose high stresses over a small area of pipe surface.

If a well is properly grouted or backfilled, no point loading will occur on the casing or screen. However, if before the grout or gravel pack is poured there is sone caving of boulders or fractured rock, a point load may occur.

Although there are no formul ae to calculate resistance to point loading, it can be said that in general RPM, FRP, wood and polymer concrete have good resistance to point loading while all thermoplastics and asbestos cement have poor resistance. For fiberglass reinforced casing, resistance to penetration by a point load increases with the thickness of the fiber layer, tensile strength and flexibility, and decreases with casing diarneter. Tensile strengths of various types of FRP casings were measured before and after point loading. 31 It was found that tensile strength decreased from $9 \%$ to $60 \%$ depending on wall thickness and casing diameter. Fildillell-wuuid casing was affected less than other types. This decrease in strength due to point loading would be important if the casing had to be pulled. In some instances, if the casing is weakened severely enough, a failure might be propagated causing the well casing to separate.

\section{Hydrostatic Compressive Strength}

Various theoretical prediction equations have been proposed for calculating hydrostatic collapse pressures. one such equation uses an ovality correction factor 32 while another equation incorporates a buckling coefficient based un suil support (K3) and casing SDR number 33. The following cquation is a combination of these two equations: 


$$
P_{c}=\frac{C_{b} E_{2}}{1-u^{2}} \cdot \frac{1}{(S D R-1)^{3}} \cdot C_{0} \quad \text { EQ. } 2
$$

where $P_{C}=$ critiçal hydrostatic collapse pressure, $\mathrm{Kg} / \mathrm{cm}^{2}$

$C_{b}=$ buckling coefficient from Figures 2 and 3

$E$ = short-term modulus of elasticity of casing material, $\mathrm{Kg} / \mathrm{cm}^{2}$

$u=$ Poisson's ratio for casing material, dimensionless

SDR = ratio of casing average outside diameter to its minimal wall thickness, dimensionless

$C_{0}=$ ovality correction factor, dimensionless

The ovality correction factor can be estimated using the following equation:

$$
C_{0}=\left|\frac{(1-d)}{(1+d)^{2}}\right|^{3} \quad \text { EQ. } 3
$$

where $d=$ casing deflection (major diameter of ellipse/diameter of "true" round casing minus 1.0)

For most casing installations, a value of .639 should be used for the $\mathrm{C}_{0}$. For casing designs where soil, gravel pack, or other material support is provided, higher collapse pressures can be expected. The modulus of support $\left(K_{s}\right)$ for these materials can be expressed as:

$$
K_{S}=K_{z} A^{2} / E h \quad \text { EQ. } 4
$$

where $K_{z}=$ modul us of subgrade reaction of the supporting material, $\mathrm{Kg} / \mathrm{cm}^{3}$

$$
\begin{aligned}
& A=\text { average casing radius, } \mathrm{cm} \\
& E=\text { tensile modulus of casing, } \mathrm{kg} / \mathrm{cm}^{2} \\
& h=\text { wall thickness of casing, } \mathrm{cm}
\end{aligned}
$$

Typical values of $K_{z}$ for various materials are: 8.3 $\mathrm{Kg} / \mathrm{cm}^{3}$ (300 $\mathrm{pci}$ ) for water saturated loose gravel, 6.92 $\mathrm{Kg} / \mathrm{cm}^{3}$ (250 $\left.\mathrm{pci}\right)$ for water saturated medium compacted sand, $2.08 \mathrm{~kg} / \mathrm{cm}^{3}$ (75 pci) for soft cl ay, $4.15 \mathrm{Kg} / \mathrm{cm}^{3}$ (150 pci) for hard clay, and $8.3 \mathrm{~kg} / \mathrm{cm}^{3}$ (300 pci) for derise sand. If the stift'ness of the supporting medium is sufficient, collapse will be prevented. The required stiffness values depend on the strength properties of the specific material used for the casing. 
In an actual casing installation, the collapse pressures may be greater or less than that predicted from Equation 2, depending on uniformity of wall thickness, rate and type of loading of the casing (uniform or linearly varying), and temperature of the casing when the external pressure is applied. Also, since the SDR is based on a minimum wall thickness, actual wall thickness may be greater than the minimum required.

The well screen is more susceptible to collapse than the casing since it is structurally weaker and the deepest section in the casing string. Screen yield strength is a function of casing cross sectional area.between the perforations. The type of loading most likely to occur at the screen is a constant radial compression. The highest pressures occur during installation when the external environment is a fluid that provides no support. Under normal operating conditions, if the casing is not perforated above pumping level, lowering the water level inside the casing produces a pressure differential on the casing equal to the difference between static water level and pumping level.

\section{E. Crushing Strength}

When fully restrained, the casing acts as a confining ring under compression. Its crushing strength or the external pressure it can safely withstand can be determined from the following equation:

$$
\Gamma_{\mathrm{e}}-2 S_{\mathrm{C}} \frac{\mathrm{t}}{\overline{\mathrm{D}}_{\mathrm{U}}}=\frac{2 S_{\mathrm{C}}}{\mathrm{DR}} \quad \text { Fn. } 5
$$

where $P_{e}=$ external pressure acting on confined casing, $\mathrm{kg} / \mathrm{cm}^{2}$

$S_{r .}=$ safe compressive stress, $\mathrm{kg} / \mathrm{cm}^{2}$

$\mathrm{D}_{\dot{\mathrm{u}}}=$ external rasing diameter, $\mathrm{cm}$

$\mathrm{t}=$ conduit. minimal wall thickness, rm

$D R=D o / t$

The safe value of $S_{C}$ for conditions of long-term loading can be generally dssuiled to be one-fifth the short-lerill lensile strength.

It has been estimated that when using coarse sand as the backfilling material, the earth pressure on a $406 \mathrm{~mm}-$ $(16-i n$.$) diameter well casing does not exceed 5.9 \times 10^{-3}$ 


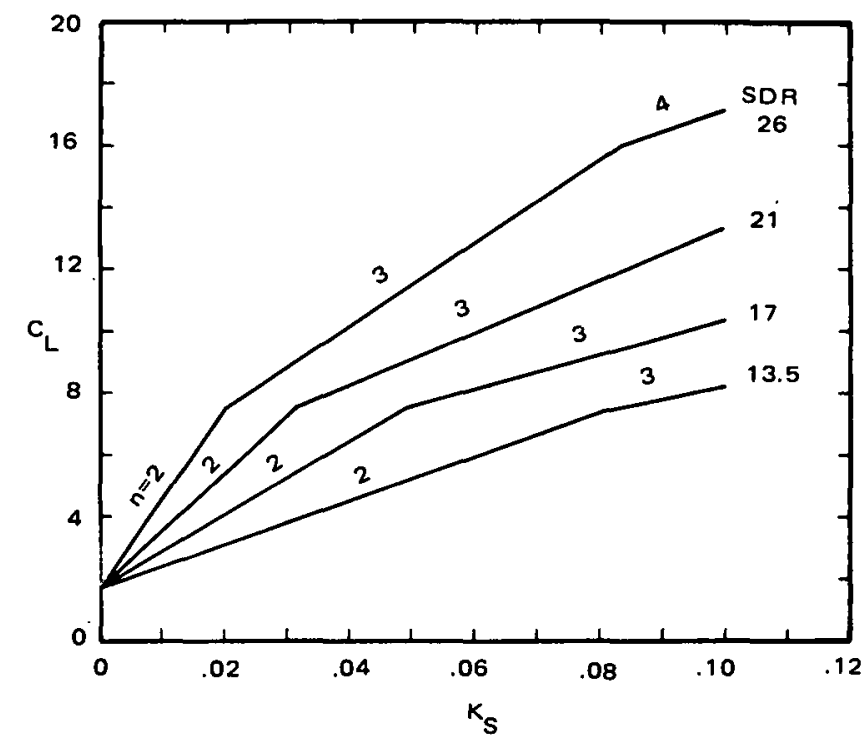

Figure 2. Buckling Coefficient for Linearly Varying Collapse Pressure (32)

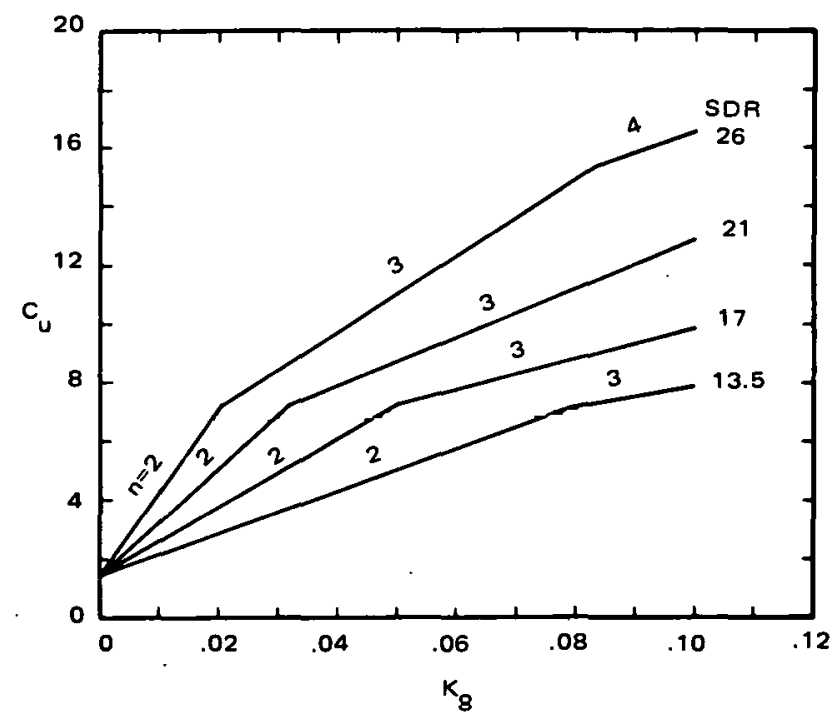

Figure 3. Buckling coefficient for uniform collapce preccure (32) 
$\mathrm{kg} / \mathrm{cm}^{2}\left(3.39 \times 10^{-2} \mathrm{psi}\right) 11$. Even with a safety

factor of five, this pressure is insignificant when compared to typical crushing strengths of casing.

F. Long-Term Creep and Stress Relaxation

If a constant load is applied and maintained on a material, it creates an initial or elastic deformation which then increases at a decreasing rate until it stabilizes. This time dependent deformation is commonly referred to as creep. Conversely, the load required to maintain an initial deformation decreases at a decreasing rate and eventually levels off to an equilibrium value. This characteristic is known as stress relaxation.

The stress level that a material can withstand willout failing is also affected by time. The longer the loading time, lhe smaller the load rcquired to achieve failure. Mechanical properties are based on short-term tests. The long-term strengths of well casing will range from $1 / 2$ to $1 / 3$ of the short-term values. The long-term modulus (stress divided by corresponding strain) ranges from about $1 / 4$ to $1 / 5$ of the short-term modulus. However, because the level of continuous loading on well casing is relatively low, long-term strength and modulus are not normally design or performance concerns 34 .

\section{G. Permissible String Length}

Maximum permissible string length for casing is normally controlled by the joint strength rather than the tensile strength of the materidl. This is especially true if the joints are threaded. In such cases, the maximum lengths are determined by restricting the axial strength in the casing to one-quarter of the tensile strength of the basic casing. This provides a safety factor of four for conditions of shnrt-t.erm loading. When casing is being lowered into a watcr filled borehole, the houyant. effect of the water reduces the tensile load on the casing string. for most plastic matertals, lhis would allow a threefold increase in string length. Wood casing string length is increased five tilles. Due to the high spccific gravity of polymer concretce, only a 70: percent increase results from bouyancy. 


\section{H. Impact Strength}

The tolerance of casing to the rigors of handling and installation is greatly determined by its impact strength. This strength is influenced by the inherent properties of the basic material, final formulation, casing diameter, wall thickness, and temperature. This property is most important during cold weather installations and handling of thermoplastic and asbestos cement pipe.

\section{Strength of Plastics}

Plastic well casings have a tendency to creep and yield under sustained stress. However, the lower strength of plastics compared with most metals is not disadvantageous because the high strength of metals is not required for well casing in most situations. Also, external shocks that could damage more rigid or brittle materials may be absorbed by plastic casing with little or no damage. This may not be the case in cold temperatures which tend to make certain plastics such as PVC and SBR, very brittle.

Besides the stress level of a given plastic, its type, grade, formulation, completeness of cure, and temperature under which it is used determines whether it will fail over a period of time.

Several common plastics comprise a family of compounds, each having somewhat different properties of hardness, stiffness, and strength. The mechanical properties of the various thermoplastic and thermoset materials are listed in Table 1 .

Each type of plastic material or composite has an upper operating temperature limit which depends on the temperature sensitivity of the material. Even within a given type of material there are different grades with higher heat resistance. Figure 4 depicts the decrease in tensile modulus with increasing temperature for various thermoplastic and thermoset materials. Fiberglassreinforced epoxy pipe has high heat resistance and maintains structural integrity up to the boiling point of water. Materials which fail in boiling water may still be useful for low-temperature applications.

For lower temperature applications, CPVC, PVC, ABS, PP, and SBR material can be fabricated with a greater wall thickness to provide additional collapse strength. Chemical crosslinking can also improve properties. 
The principal loss of strength in a high-temperature corrosive environment takes place in the first three months, with only minor changes occurring after that time. This trend may be extrapolated to predict strength after several years exposure.

Fiberglass-reinforced epoxy pipe, being a thermoset, is stronger and more temperature resistant than thermoplastic pipe. It has been used extensively by the petroleum industry in corrosive environments for small-diameter installations in deep wells and as pressurized distribution pipe. 203- to 254-mm (8-10 in) diameter .508-cm (.2 in) walled epoxy fiberglass casing has been used to depths of 90 meters $(295 \mathrm{ft})$ for water well casings in Pakistan and the United States. The $.508-\mathrm{cm}(.2 \mathrm{in})$ and thinner-walled epoxy casing is reported to collapse under the stress of normal development, and the slotted pipe, used as screen, has a relatively low percentage of open area. Thus, there has been a reluctance to experiment with this type of pipe in large-diameter deep wells in unconsolidated formations, regardless of the advantages. The collapse resistance could be improved by increasing the wall thickness-diameter ratio. A .61-cm (.24 in) walled FRP vinylester casing was successfully used in a 366-m (1200 ft) well transmitting $93^{\circ} \mathrm{C}\left(200^{\circ} \mathrm{F}\right)$ water for uranium processing 35 . A few large-diameter casings with $1.27-\mathrm{cm}$ (.5 in) wall thickness or heavier have been installed in wells for special purposes in the United States 36 . A $178 \mathrm{~mm}$ (7 in) diameter, 1.27 $\mathrm{cm}(.5 \mathrm{in})$ thick FRP epoxy casing was recently installed in a 2,000-m (6562 ft) deep geothermal well near Paris which supplied very corrosive $60^{\circ} \mathrm{C}\left(140^{\circ} \mathrm{F}\right)$ water ${ }^{37}$.

Since reinforced plastic casings have definite temperature limitations, overdesigning can etther remove them from consideration or require a more sophisticated and/or costly material. If a fabricator knows the operating temperatures, he will design the casing with sufficient safety factors to cover the conditions. In some cases, this may be as simple as an increase in thickness to compensate for the loss of physical properties at el evated temperatures. Th1s will increase the price and may remove FRP from consideration on economic grounds alone.

Reinforced plastic pipe is about one-quarter the weight of an equal thickness of carbon steel and even slightly lighter than aluminum. Because of this, an FRP well casing can be made stiffer than steel on a equal weight basis. 


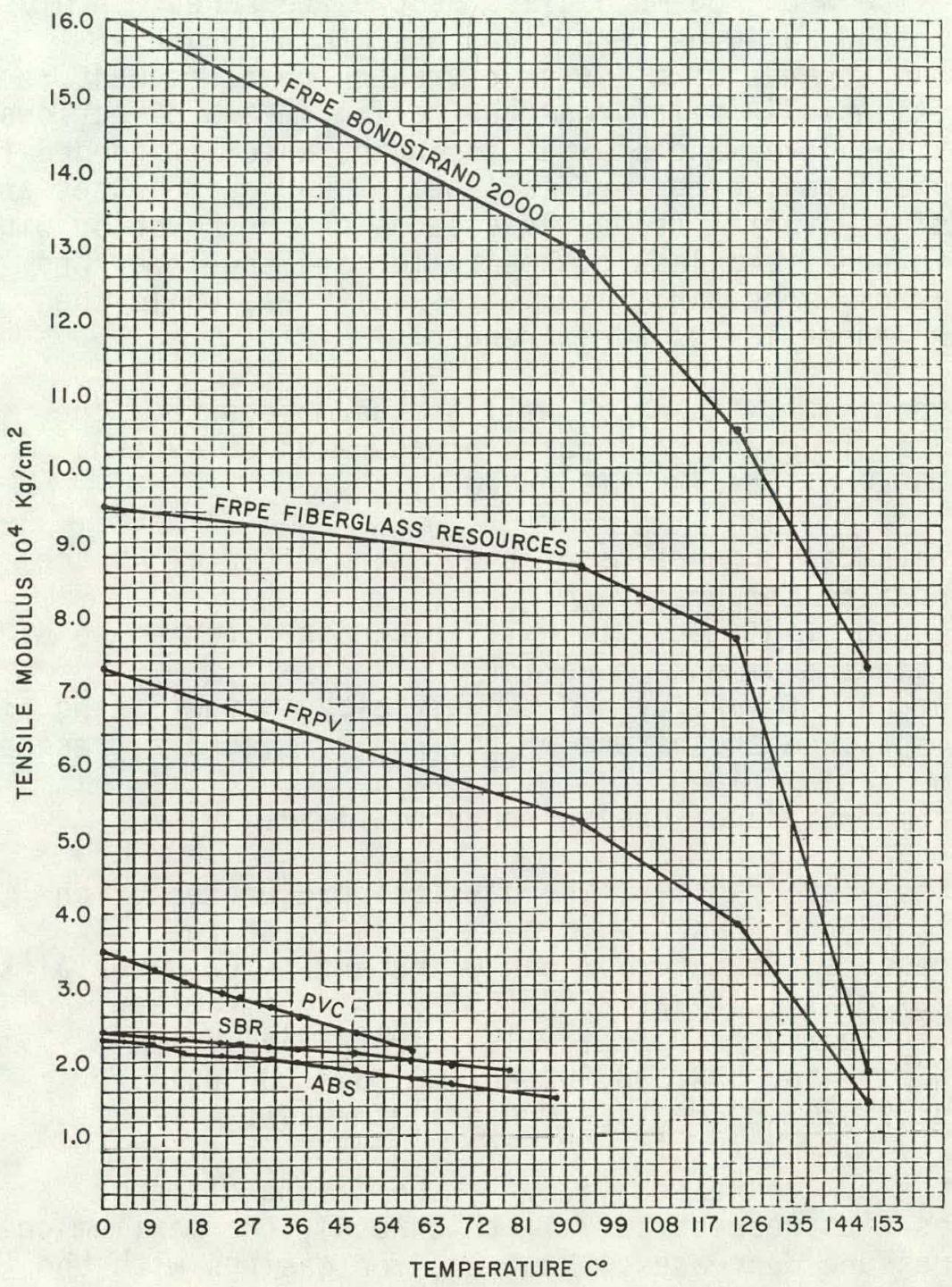

Figure 4. Effect of Temperature on Tensile Modulus of Various Nonmetallic Casings 
This property is sometimes called structural efficiency or strength-to-weight ratio.

In principle, the greater the glass content, the higher the mechanical strength and stiffness. This is true up to a point. Pipe with too much glass becomes weakened. A glass content of 30 to 40 percent gives opt imum strength. Continuous strands of glass give greater reinforcement. Fabric essentially reinforces the casing in two directions. It sometimes gives added axial strength, which is needed for handling and resisting vertical loads. RPM casing uses an inexpensive material (sand) in a sandwich construction with the resin and riberglass composite forming the inner and outer layers. The sand layer gives stiffness while the outer and inner layer's add strength.

Thermoplast.ic casing as well as thermosets have the ability to withstand collapsiny pressure under cxternal load. This ability is influenced by:

1) The physical properties of the casing material at the appropriate temperature

2) The ratio of diameter to wall thickness referred to as the Standard Dimension Ratio (SDR)

3) The amount of ovality and eccentricity in the casing pipe

4) The magnitude and nature of the residual stress present in the casing pipe

5) The temperature of the surrounding fluid.

Of the above factors, the physical properties of the material and the SDRs are used in arriving al the collapse pressure the material can withstand. The material's modulus of elasticity at $20^{\circ} \mathrm{C}\left(68^{\circ} \mathrm{F}\right)$ is an important physical property. Typical values are $22,496 \mathrm{~kg} / \mathrm{cm}^{2}$ $(320,000 \mathrm{psi})$ for $\mathrm{SBR}_{3} 23,902 \mathrm{Kg} / \mathrm{cm}^{2}(340,000 \mathrm{psi})$ for $A B S$, and $29,526 \mathrm{~kg} / \mathrm{cm}^{2}(420,000 \mathrm{psi})$ for PVC.

As the SDR increases (i.e. as the casing diameter increases with respect to wall thickness), the maximum collapse pressure decreases. However, for casings with the same SDR number, collapse pressure is independent of casing diameter.

A well casing with packing to support the casing and prevent collapse will allow greater depth as long as the drawdown or head differential is within design limits. The ASTM F480 standard for thermoplastic water well casing 
states that "The depth at which thermoplastic water well casing can be placed is a design judgement. Thermoplastic water well casing pipe has been placed over $2000 \mathrm{ft}$ deep, but the water level inside the well casing pipe is less than $100 \mathrm{ft}$ from the surface." 38 Because of the wide range of earth formations, water levels in the wells, gravel pack or cementing in a larger hole versus no backfill in a tight hole, and the experience and workmanship of the driller, there is no practical method for determining an absolute depth limit for any thermoplastic well casing.

Other than by experience it is difficult to estimate combined stresses on the casing and screen during installation, development, and operation. Many wells have been constructed using casings having a collapse strength as low as 40 psi. With increasing depth greater allowance should be made for these stresses. 39

Based on the experience of well drillers and manufacturers' recommendations the following general depth limits have been established for various types of casing materials:

$\begin{array}{llrl}\text { WOOD } & - & 2000 \mathrm{FT} & -610 \mathrm{M} \\ \text { CPVC + PVC } & -1000 \mathrm{FT} & -305 \mathrm{M} \\ \text { ABS } & - & 1000 \mathrm{FT} & -305 \mathrm{M} \\ \text { SBR } & - & 1000 \mathrm{FT} & -305 \mathrm{M} \\ \text { RPM } & - & 1200 \mathrm{FT} & -366 \mathrm{M} \\ \text { FRPV } & - & 1200 \mathrm{FT} & -366 \mathrm{M} \\ \text { FRPE } & - & 6562 \mathrm{FT} & -2000 \mathrm{M}\end{array}$

These depths assume an even, non-bridging gravel packing or grouting with the Haliberton method. 40 Actual depth limits may be greater or less than those listed depending on the temperature and stability of the formation.

\section{j. Strength of Polymer Concrete}

I he compressive strength of polymer concrete varies with polymer content and sand-cement ratio. It decreases from $1968 \mathrm{Kg} / \mathrm{cm}^{2}$ (28000 psi) with 12 wt \% polymer to 1195 $\mathrm{Kg} / \mathrm{cm}^{2}$ (17000 psi) for a 20 wt \% polymer loading. Increases in cement content from $10 \%$ to $30 \%$ result in increases in compressive strength from $1406 \mathrm{Kg} / \mathrm{cm}^{2}(20000$ psi) to $1898 \mathrm{~kg} / \mathrm{cm}^{2}(27000 \mathrm{psi})$. Reductions in compressive strength ranging between 14 to 18 percent were noted for samples exposed for 180 days to low-temperature, 
low sal inity geothermal fluids. Beyond that time, the strength remained essentially constant 41 . The tensile strength of polymer concrete with a 90:10 ratio of sand to portland cement is relatively low, $119.5 \mathrm{~kg} / \mathrm{cm}^{2}(1700$

psi). However, its tensile modulus, $45 \times 10^{4} \mathrm{~kg} / \mathrm{cm}^{2}(6.4$ $\times 10^{6}$ psi), is higher than any other nonmetallic pipe material. The maximum depth that polymer concrete can be installed in low-temperature geothermal wells is approximately $610 \mathrm{~m}(2000 \mathrm{ft})$.

\section{K. Asbestos Cement Strength}

Asbestos cement pipe has been used for water well casing, but it has low joint strength (especially at high temperatures and cannot tolerate abuse due to its brittleness 37 .

A recent analysis of asbestos cement piping systems for geothermal plants revealed that a complex control system is required to reduce pressure and thermal stress on the pipe. For well installations, other loading conditions such as setting packers, perforating casing, etc., as well as mechanical coupling problems and loss of asbestos fiber to the fluid would make this material unsatisfactory for $1,524-\mathrm{m}(5000 \mathrm{ft})$ deep well s with fluid temperatures of $129^{\circ}$ to $143^{\circ} \mathrm{C}\left(264^{\circ} \text { to } 289^{\circ} \mathrm{F}\right)^{42}$. However, for shallower $(<305 \mathrm{~m}),(<1000 \mathrm{ft})$ lower-temperature $\left(<121^{\circ} \mathrm{C}\right),\left(<250^{\circ} \mathrm{F}\right)$ wells, asbestos cement can be successfully used. 


\section{RESISTANCE TO PHYSICAL AND BIOLOGICAL ATTACK}

\section{A. Plastics}

Plastic well casing is virtually immune to attack by fungi, bacteria, and insects, but can be damaged by rodents. Many types of plastic casing are tough and can resist abrasion. In many wells, plastic casing or plastic-lined steel casing has successfully replaced and outlasted steel pipe in severe service applications.

\section{B. Asbestos Cement}

After one year of testing in various geothermal environments, erosion damage in transite pipes appeared to be minor 17 .

\section{Wood}

Biological attack is the major hazard with wood casing. This can be caused by rot, fungal attack, or insects. There are two ways to avoid biological attack: use a wood with a high degree of natural durability; treat the wood with a preservative.

\section{THERMAL PROPERTIES OF NONMETALLICS}

\section{A. Heat Resistance}

Heat resistance is the long-term resistance to thermal degradation bel ow the flammability temperature. Heat resistance of FRP derives largely from the resin, and partly from fillers. As a class, the aromatic-heterocyclic' polymers are very heat resistant. However, these polymers are very expensive because the required monomers are costly. Poly.imides resist heat almost a.s well as aromatic heterocyclic polymersand are much less expensive. However since they are subject to hydrolosis, they were not considered for use in geothermal wells.

Like thermoplastic resins, thermosetting resins can be fabricated at elevated temperatures and pressures, although some types can be cast at room temperature. In this case, the significant difference in thermosets is that the process is irreversible. Once formed, these materials cannot be softened and reshaped by the application of heat. This characteristic gives them higher heat resistance. 
Thermosets undergo cure in the molding or forming process and becone substantially infusible due to chernical reactions produced by heat and/or added chemicals.

Well casing failure may arise from a reduction in mechanical strength at high operating temperatures. In addition, exposure to high concentrations of acids and salts and high pressures may deleteriously affect the performance of a material. The higher the temperature, the more rapid the loss of properties.

In the case of thermoplastic well casing, degradation due to thermal aging may be more pronounced than chemical attack degradation since thermoplastics are very resistant to most chemicals. Underwritcr's Laboratories have determined the heat resistance or thermal endurance of various propertics until foilure occurred alteil dyilly al edch uf several aglng temperatures. Ihe logarithm of time to failure at each temperature, when plotted against. the reciprocal of the absolute temperature and subjected to regression analysis, normally follows a straight line. Extrapolation of this straight line indicates the long-term capability of a material to resist thermal degradation.

The temperature index of a material is a nominal number equal to the temperature value obtained from the thermal endurance curve at a specified time (usually 100,000 hours). It correlates numerically with the temperature rating or maxirnum temperature in degrees Celsius above which a material may degrade prematurely and become unsafe. The time value associated with the temperature index is based on a comparison with similar test results of a material which has provided 1nng, arrepted servire: The temperature index provides a very valuable tool to evaluate materials which are exposed to heat sources having no other degradation influences. In the case of thermoplastics and thermoset resins, other degradation influences (such as corrosive chemicals) will have little or no effect on the reduction in mecharical properties.

The-temperature index has a built. in 2:1 safety fartor. That is, the end-of-life at each aging temperature is reported as the time when a property value has decreased to 50 percent of its unaged level. If the thickness and composition of a finished product provides a higher than normal factor of safety, as in the case of fiberglass reinforced pipe, an end-point less than 50 percent can be selected. 


\section{B. Heat Transfer}

The heat transfer or themal conductivity values for plastics are considerably lower than for metals. For example, the value $\mathrm{K}$ in $\mathrm{J} . / \mathrm{sec} . \mathrm{cm} .{ }^{\circ} \mathrm{C}$ for PVC casing ranges from 13.81 to $4.22 \times 10^{-4}$ and from 16.74 to $34.31 \times 10^{-4}$ for FRP. Transite pipe has the lowest range of 1.76 to 4.10 $\times 10^{-4}$ due to its asbestos cement content. Values for carbon steel are approximately $1082 \times 10^{-4}$. For

low-temperature geothermal well construction, the lower conductivity of nonmetallics considerably decreases heat loss through the casing. However, this property is useful in applications where thermal gradients are large or temperature cyclical. Thermal stresses during initial flow or interrupted flow in a geothermal well may damage casing materials with low thermal conductivities.

\section{Coefficient of Thermal Expansion}

Thermoplastic materials have substantially greater coefficients of thermal expansion than other types of material. The coefficient of thermal expansion varies considerably among plastics. Generally, it ranges from 2 to 20 times that of steel $\left(1.13 \times 10^{-5} \mathrm{~cm} / \mathrm{cm}\right.$ per $\left.{ }^{\circ} \mathrm{C}\right)$. Techite is the only plastic that expands less than steel with a coefficient similar to that of the miscellaneous materials. The effects of expansion should be ascertained before design and installation of the casing so that a determination can be made whether steps should be taken to control them. Usually, thermal expansion is not a problem with solid wall plastic casing due to shallow depths and low temperature, and a relatively low modulus of elasticity for the casing material.

\section{FLUID FLOW CHARACTERISTICS}

Thermoplastic and thermosetting materials have lower roughness coefficients than metal and other nonmetallic materials. Consequently, friction head is lower, and pumping costs can be reduced.

After a relatively short time, metal pipe can acquire internal deposits that impede flow and increase pressure losses. However, the interior walls of thermoplastic pipe usually remain smooth even in corrosive service. The result is lower pressure loss and higher volume. 
Friction loss in plastic well casing remains constant over extended periods of time. This contrasts with some other materials where the value of the Williams and Hazen C-factor (constant for inside roughness) decreases with time. As a result, the flow capacity of thermoplastics is greater under fully turbulent flow conditions during pumping.

Tests made both with new casing and old casing that had been in service revealed that the C-factor varies between 160 and 165 for thermoplastic casing, and between 145 and 190 for FRP casing 43, 44. On the other hand, the Cfactor for metallic casing varies from 65 to 125, depending on age and interior roughness. Values for other nonmetallic casing are 140 for asbestos cement and 100 to 120 for polymer concrete and wood.

The greater C-factor values for plast ic casing enable the use of a smaller-diameter casing to obtain the same or even lower friction loss than metal casing. In pumped wells, lower friction head may reduce pumping costs. .

\section{CORROSION RESISTANCE}

Corrosion comes in many forms, depending on the types of materials involved and the nature of the geothermal brine. The corrosive effects of brine have been discussed in detail in Appendix B.

Corrosion musl commonly applies to mctals, although all materials (including ceramics, wood, plastics, and rubber) deteriorate to some extent when exposed.to particular combind.ions of liquids and gases. Table 2 lists the chemical resistance of various materials to corrosive liquids and gases.

Although the corrosion resistance of nonmetallic materials is very important, most studies of corrosion deal only with metals because they are more commonly used in geothermal wells and have faster corrosion rates. The results of testing various materials in low-temperature geothermal brines and flowing sea-water up to $121^{\circ} \mathrm{C}\left(250^{\circ} \mathrm{F}\right)$ are shown in Table 4 of Appendix B. Data from the sea water tests give only relative corrosion resistance and general trends. Testing of nonmetallic materials in geothermal environments is required. 


\section{A. Metals}

The corrosion resistance and use of metals in geothermal systems have been described in detail. 6 Conventional casing steels such as API grades $\mathrm{H} 40$ and $\mathrm{J} 55$ are used satisfactorily in geothermal wells. Due to the absence of oxygen, corrosion rates are usually low. However, shallow aerated ground water or deeper water cont aminated with oxygen through reinjection well systems can produce significant corrosion of metals. In such cases, the casing is completely cemented from top to bottom so that the cement sheath functions as the casing if the steel casing corrodes.

Accidental deflection of high-velocity steam and water during initial discharge of geothermal wells can cause dramatic erosion-corrosion damage to casings. During normal operation, erosion-corrosion is usually not a significant problem.

Severe thermal stresses resulting from the intermittent flowing of geothermal wells can produce casing fractures and joint failures. In low-strength steel casing, this failure probably occurs by mechanical action, whereas medium and high-strength steel casings fail more often by delayed fracture. The danger of casing fracture from mechanical stress corrosion and delayed fracture causes can be reduced or el iminated by keeping wells discharging or hot after initial discharge.

Pitting is a form of corrosion that creates many small holes over the surface of a metal. It may occur where the coating of metal is absent or at sites of various deposits.

Stress corrosion cracking is caused by a combination of internal stresses that occur during processing and corrosion. In this case, corrosion proceeds very rapidly at the spot where the stresses are concentrated, and failure of. the material may occur suddenly. $\mathrm{H}_{2} \mathrm{~S}$ stress cracking is liiusl severe below $66-79^{\circ} \mathrm{C}\left(151^{\circ}-174^{\circ} \mathrm{F}\right)$, while $\mathrm{Cl}$ stress cracking increases above $66-71^{\circ} \mathrm{C}\left(151^{\circ}-160^{\circ} \mathrm{F}\right)$.

Intergranular corrosion occurs at the grain boundaries of a metal due to the presence of impurities or stresses. Corrosion occurs on exposure of the metal's surface to a corrosive medium. The boundaries become the anodes, while the grains themselves are cathodes. 
TABLE 2 RELATIVE CHEMICAL RESISTANCF. OF MATERIALS TO CORROSIVE ENVIRONMENTS

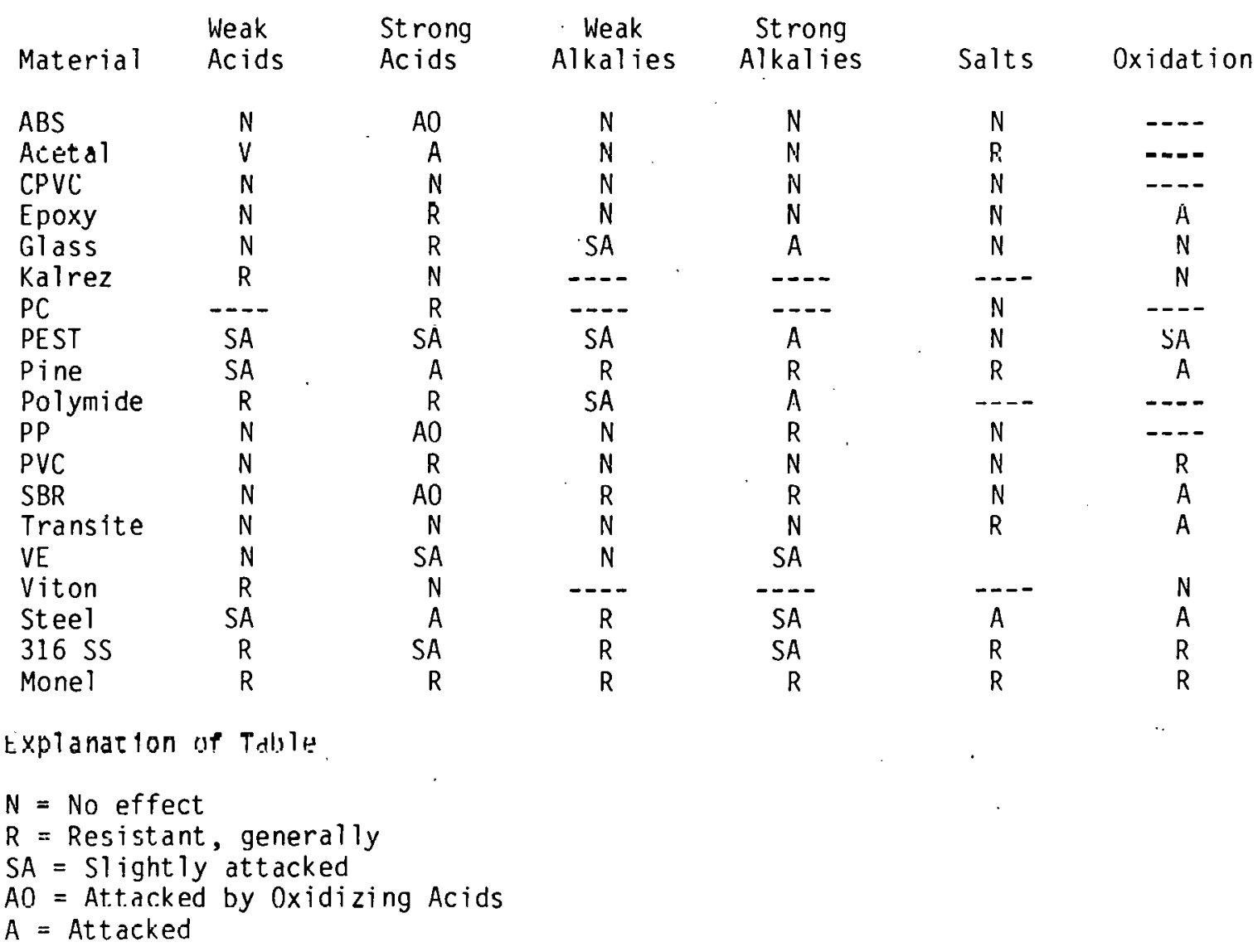


The localized corrosion mechanisms described in the previous paragraphs have been found to be more important than general corrosion in the selection of materials of construction for geothermal applications. 3

Fatigue corrosion may be very important in well construction. However, practically no data exists on fatigue corrosion in geothermal environments. Severe corrosion fatigue was noted in salt solutions containing dissolved $\mathrm{H}_{2} \mathrm{~S}$, which are similar to geothermal fluids. 45

\section{B. Thermoplastics}

Thermoplastic materials have outstanding resistance to attack by many chemicals found in geothermal environments. The factors that determine the suitability and service life of each particular combination include:

1) the specific chemical and its concentration

2) the specific plastic material used.

3) joining method

4) dimensions of the casing

5) pressure

6) temperature

7) period of contact

8) other service conditions which may introduce stress concentrations in pipes or fittings.

Although the effect of each chemical is unique, some chemicals can be categorized by their ability to react with various plastics. Water solutions of neutral inorganic salts such as sodium chloride generally have the same effect on thermoplastic piping materials as water alone. Some oxidizing salt solutions at elevated temperatures and/or high concentrations may attack some plastics. Generally, the resistance of a particular plastic decreases as the concentration of a chemical increases.

Chemical attack on plastics takes two forms. One is a solubility or swelling phenomenon. In this case, if the chemical is completely removed from the plastic, the plastic generally returns to its original condition and is not destroyed. However, if the plastic has a compounding 
ingredient that is soluble in the chemical, the properties of the plastic may be changed due to the removal of this ingredient. In this instance, the fluid passing through the pipe would be contaminated. This seldom happens because such ingredients are either not used in pipe compounds, or they are incorporated in the plastic composition in such small amounts that they cannot be leached out to any significant extent.

The other type of attack involves a permanent change in the polymer or base resin molecules through chain scission, crosslinking, oxidation, and substitution reactions. These changes may be profound and the original properties of the plastic cannot be restored by removing the chemical.

A nonchemical attack that some plastics are subjected to is environmental stress cracking. When a plastic casing is stressed during bending, twisting, or cutting, cracks may develop when it is exposed to certain chemical environments. This mechanism is believed to be due to the action of a sensitizing agent on minute surface flaws in a stressed or strained polymer. 32

The chemical resistance of plastics varies greatly, not only from type to type but among grades of the same type. There may also be minor variations among commercial products of the same type and grade. The chemical resistance of the various types of thermoplastic materials to corrosive media is described in Table 2.

The chemical resistance of plastic piping is basically a function of (a) the chemical resistance of the compound used and (b) the processing of the plastic so that its full chemical resistance is developed. In general, the smaller the quantity of compounding additives, the better the chemical resistance. Most plastic pipe compounds covered by current ASTM specifications use a minimum amount of compounding ingredients.

Chemical reactions accelerate with temperature increases. Thus, operating temperatures help or hinder a material's ability to resist chemical attack. Degradation cffects, such as croselinking, oxidation, and hydrolysis are the primary mechanisms that. rhange the mechanical properties of plastic well casing exposed to high temperatures. Degradation is caused by pyrolytic or chemically enhanced scission of the chain molecules. Pyrolysis, if occurring 
alone, can lead to a progressive reduction in molecular. weight accompanied by loss of strength, elongation, and toughness. A decrease in softening temperature and lower creep resistance follows. In general, the rate of polymer degradation is doubled with each $10^{\circ} \mathrm{C}\left(18^{\circ} \mathrm{F}\right)$ increase in temperature.

Crosslinking consists of the formation of bonds between individual polymer chains as a result of degradation. Crosslinking ties the molecules into a rigid network and produces a hard brittle structure which cannot be melted or dissolved. Oxidation, which is often catalyzed by water, promotes fragmentation to a brittle, lower molecular weight structure.

In most cases, all three mechanisms occur simultaneously. Their effects may temporarily balance each other, creating the impression that no changes are taking place. Eventually, one of the reactions prevails, leading either to a drastic softening or embrittlement of the polymer.

Improper joining methods or sloppy workmanship may decrease the joint's resistance to chemical attack. Special considerations for joining nonmetallic well casing and screens are discussed in Appendix D.

\section{Thermosetting Resins}

In general, thermosetting resins are less resistant to chemical attack than are thermoplastics (Table 2). They do not dissolve like metal, but they do degrade or corrode due to swelling, loss in mechanical properties, softening, hardening, spalling, and discoloration.

No filler or reinforcement will compensate for the failings of the resin. Acid-and alkali-resistant polyesters and acid-resistant epoxies have good corrosion resistance. Uf the common fillers, china clay and silica are good overall, while calcium carbonate has good alkali resistance but is poor in acids. Better performance might be expected from corrosion=resistant glass fibers.

Higher resin performance is usually necessary for products exposed to corrosion. The major thermoset resins for this particular application are polyesters (both orthophthalic and isophthalic), phenolic, vinyl esters, and 
epoxy bisphenol-A-fumarate. The preceding list is arranged in ascending order of chemical resistance and cost. Epoxy is highly resistant but more costly. Special manufacturing and handling requirements of individual resins also influence cost.

The degree of corrosion resistance imparted by polyester resins depends on their molecular structure. The bisphenol-based products are best, followed by resins derived from terephthalic or isophthalic acid and the 'general purpose' resins based on orthophthalic acid which are mainly used in applications where corrosion resistance is not of prime concern.

The chemical resistance of epoxy-type plastic depends on the hardener that is used with the resin. The hardener is not a catalyst because it becomes part of the plastic. Therefore, an aromatic polyamine hardener will give a greater chemical resistance than an aliphatic polyamine hardener or a polyamide hardener. Also, a b isphenol-A/epichlorodydrin epoxy resin will have a different chemical resistance than an epoxy novolac resin.

Choice of resin should be based on the major composition and impurities present in the system. Parts per million of a trace material can make the difference between a resin's success and failure in an application.

Attack of chemicals on reinforced polyester or epoxy pipe may occur in several ways. These may be broadly classified as follows:

1. Disintegration or degradation of a physical nat.ure due to absorption, permeation, solvent action, etc.

2. Exidation where chemical bonds are attacked

3. Hydrolys is where ester linkages are attacked

4. Dehydration (rather uncumion)

5. Radiation

6. Thermal degradation, involving depolymerization and pussibly repolymerization

7. Combinations of these attacks and possibly others.

As a result of such attacks, the material may he affected in one or more ways. For example, it may be embrittled, softened, charred, crazed, del aminated, discolored, dissolved, blistered, swelled, etc. 
Cure plays an important part in the chemical resistance of a polyester or epoxy, as does the construction of the laminate itself and the type of glass or reinforcing used. The degree and nature of the bond between the resin and the glass or other reinforcement also plays an important role.

In addition to the combination of various mechanisms that can occur simultaneously, synergistic effects of chemical mixtures probably enhance chemical attack.

D. Other Nonmetallic Material

There is little systematic information on the performance of nonmetallic construction materials in geothermal fluids, particularly for plastics and protective coating materials. An accelerated aging of plastics through contact with geothermal gases and waters has been observed in field tests 17 .

Geothermal waters do not usually have an adverse effect on concrete unless the waters have been aerated, which provides subsequent acid sulfate attack. In some situations, epoxy resin coatings on concrete have provided a satisfactory protection, although the persistence of such coatings under hot and acid conditions is questionable. Polymer-impregnated concrete (PIC) and polymer concrete (PC) are chemically stable in geothermal environments.

Resistance to corrosion is a function of the monomer and the aggregates used in compounding. After testing PC in brines at temperatures up to $160^{\circ} \mathrm{C}\left(320^{\circ} \mathrm{F}\right)$ for over a year, essentially no deterioration was detected 46 .

Many paints have short lifetimes on geothermal equipment exposed to sulfurous and saline atmospheres. The most satisfactory results have been obtained with epoxy paints after careful sand blasting or scraping of surfaces. Silicone paints have also given promising results. In general, oil, acrylic, vinyl, phenolic, chlorubber, polyester, and polyurethane paints are unsatisfactory. Lead-containing paints blacken rapidly and must be avoided.

The corrosion resistance of elastomers in geotherma 1 brines has been intensively studied 6, 47. Testing in high-temperature brines showed that Viton and Kalrez had superior corrosion resistance. The use of these materials in geothermal wells is limited to formation packers and gaskets for certain types of joints. 
Transite is considered one of the most corrosion resistant pipes in general use. This property is achieved during autoclaving--the process used to cure transite pipe. However, chemical leaching of the cement binder to a depth of $1 \mathrm{~mm}$ (.04 in) was observed in transite pipe exposed to acid sulfate fluid for over a year. 17

In general, wood is limited to applications where ground water contains low to moderate concentrations of acids and salts. Impregnating the wood with waxes and plastics helps reduce chemical attack. Cypress, pitch pine, Douglas fir, and redwood have favorable resistance to corrosive environments, and are particularly useful in the presence of acid fumes which rapidly corrode steel and concrete.

\section{SCALE RESISTANCE}

The ability of a material to resist scaling will determine the lifetime of a geothermal well. In contrast to corrosion, the effects of scaling are most pronounced at lower temperatures. Thus, a material with high scale resistance need not have a high heat resistance. Scale composed of magnetite $\left(\mathrm{Fe}_{3} \mathrm{O}_{4}\right)$, hausmanite $\left(\mathrm{Mn}_{3} \mathrm{O}_{4}\right)$, and silica $\left(\mathrm{SiO}_{2}\right)$ has formed in wellhead plumbing. This scale is reported to form on any surface; even such inert materials as Teflon are soon deeply coated.

Formation of such scales is a consequence of the material used for well casing as well as other factors discussed in Appendix B. In steel casing, a series of reactions occur between iron ions and water:

$$
2 \mathrm{Fe}^{+3}+\mathrm{Fe}^{+2}+1 \mathrm{H}_{2} \mathrm{O}-\mathrm{Fe}_{3} \mathrm{O}_{4}+8 \mathrm{H}^{+}
$$

Similar reactions occur between manganese ions and water. These reactions are reversible as long as the solution remains in contact with the scale. However, if the solution contacts a material that consumes acid (e.g. limestone) or a reactive metal (e.g. iron), the equilibrium is disturbed by removing acid, and more scale and acid form while iron is removed from solution.

Relative scale resistance for plastics increases from FRP to polyesters and polysulfides to fluorocarbon and hydrocarbon polymers 48. Scale buildup in plastic well casing is rare, especially from deposition of corrosion 
products. However, German sources report iron incrustation deposits on plastic screen as being a serious problem, and fiberglass slotted pipes in West Pakistan installed 14 years ago are becoming incrusted ${ }^{49}$. In another example, a polymer concrete-lined pipe showed no scale accumulation after exposure to a $26,000 \mathrm{ppm}$ brine at $160^{\circ} \mathrm{C}\left(320^{\circ} \mathrm{F}\right)$ for 4,410 hours, while a layer of scale approximately $51 \mathrm{~mm}$ (2 in) thick accumulated on carbon steel pipe after 2,000 hours. ${ }^{46}$

If corrosion rather than pressure reduction is the principal triggering mechanism for incrustation, the use of nonmetallic well casing and screen should markedly improve long-term well performance and greatly reduce maintenance and rehabilitation cost.

VIII. WEATHERING RESISTANCE OF NONMETALLICS

Although nonmetallic well casing is designed for subsurface conditions, prolonged exposure to atmospheric conditions during transportation and storage may result in significant deterioration. Photochemical (ultraviolet) degradation of thermoplastic well casing, like thermal degradation, results in polymer chain-scission and crosslinking, but occurs through a different mechanism. Since the photochemical process is particularly destructive under normal weather conditions, absorbers are usually added to block out ultraviolet radiation. This produces a sharp reduction in photochemical degradation but slightly increases thermal degradation through black-body absorption.

Durability of glass-reinforced thermoplastics in outdoor weathering was investigated for intervals up to two years 50. The results showed no significant decay of tensile or impact properties. Furthermore, the property loss over three months was comparable to that for one year. This behavior is probably caused by the initial water absorption which results in the rapid formation of partially degraded or photo-oxidized surface. This surface is an effective light barrier which prevents further degradation.

Polypropylene and PVC showed an increase in tensile strength and a slight decrease in impact strength between three months and two years. This may be attributed to stress relief and photochemical crosslinking. 
In addition to fading, chalking, and general loss of surface gloss, the combination of solar radiation, temperature changes, oxygen, and water involved in weathering can cause degradation of an exposed nonmetallic pipe and deteriorate its physical properties. The ultraviolet component of the solar spectrum is most damaging to thermoplastics. The rise in temperature that occurs upon exposure to direct sunlight also accelerates the rate of degradation. Sharp temperature changes can cause surface cracking due to associated shrinking and swelling. Rain and high humidities can leach components from the materials, which can also result in a faster rate of degradation. Cyclic changes in humidity are al so detrimental, and associated dimensional changes can contribute to degradation. The weatherability of thermoplastics can be improved by adding pigments or ultraviolet stabilizers.

\section{HYDROLYSIS RESISTANCE OF NONMETALLICS}

Thermoplastic well casings must be able to withstand continuous, long-term hydrolyt ic exposure at high temperatures. The interaction of water, both aqueous and vapor, and polymer varies widely. Thermoplastic resins do not simply dissolve in water. They exhibit swelling, stress-cracking, and wicking due to the presence of water molecules, ionic (salt) impurities, dissolved air, and bacteria.

Water transport throughout a thermoplastic casing wall occurs by two processes -- sorption and diffusion. Sorption is the entrance of water molecules into the resin, and diffusion is the distribution of water molecules by random molecular motion throughout the resin. If the water is in the vapor form, the equilibrium water absorption is a function of the relative humidity. At low humidity, a linear relationship exists between water absorption and consequent dimensional change.

In an aqueous or high-humidity environment, the effects on a thermoptastic are more rapid. Equilibriam is controlled to a greater extent by sorption, which is a function of water contact or wetting. No thermoplast ic is completely wet-out by water, however, since the surface tension of water is too high. In fact, there appears to be a correlation between hydrolytic stability (in terms of property loss) and critical surface tension of a polymer. The 30 percent glass-reinforced polypropylene has outstandinglong-term resistance in $100^{\circ} \mathrm{C}\left(212^{\circ} \mathrm{F}\right)$ water. Polyimide is very sensitive to hydrolysis. 
APPENDIX D SPECIAL CONSIDERATIONS IN THE DESIGN AND

CONSTRUCTION OF LOW-TEMPERATURE GEOTHERMAL WELLS

USING NONMETALLIC MATERIALS

I. DRILLING METHODS

The drilling methods used for water wells are essentially the same as those employed for low-temperature geothermal well construction, but the method of casing installation differs. Several drilling methods exert severe mechanical stress on the well casing, which eliminates their use with nonmetallic well casing.

(1) Cable-tool Percussion Drilling

(2) California Stovepipe Method

(3) Jet Drilling

(4) Hydraulic Percussion Drilling

(5) Earth Auger Method

(6) Hydraulic Rotary Drilling

(7) Air Rotary Drilling

(8) Reverse Circulation Drilling

Each of the above methods is described here on the basis of stresses imposed on the well casing. Each method has its advantages, but the most suitable method for a given situation depends on the character of the formations to be penetrated, well diameter, depth, ease of construction, and construction costs.

The cable-tool percussion method works by regularly lifting and dropping a heavy string of drilling tools in the borehole (see Figure 1). The drill bit crushes the rock into fragments which mix with the water, forming a slurry or sludge. If no water is present in the formation, water must be added to form the slurry. The slurry is removed

periodically with a pump or bailer. When drilling in hard or consolidated formations, the well casing does not need to be set as drilling proceeds. However, the casing must closely follow the drill bit in order to keep the borehole open in soft or unconsolidated formations. Generally, the casing is driven, creating great mechanical stress on the casing. In order to avoid these stresses, the pull-back method can be utilized. This method drills through the formation using standard procedures. Once the desired depth is attained, a nonmetallic casing is inserted and the steel casing is pulled back out of the borehole for reuse. 


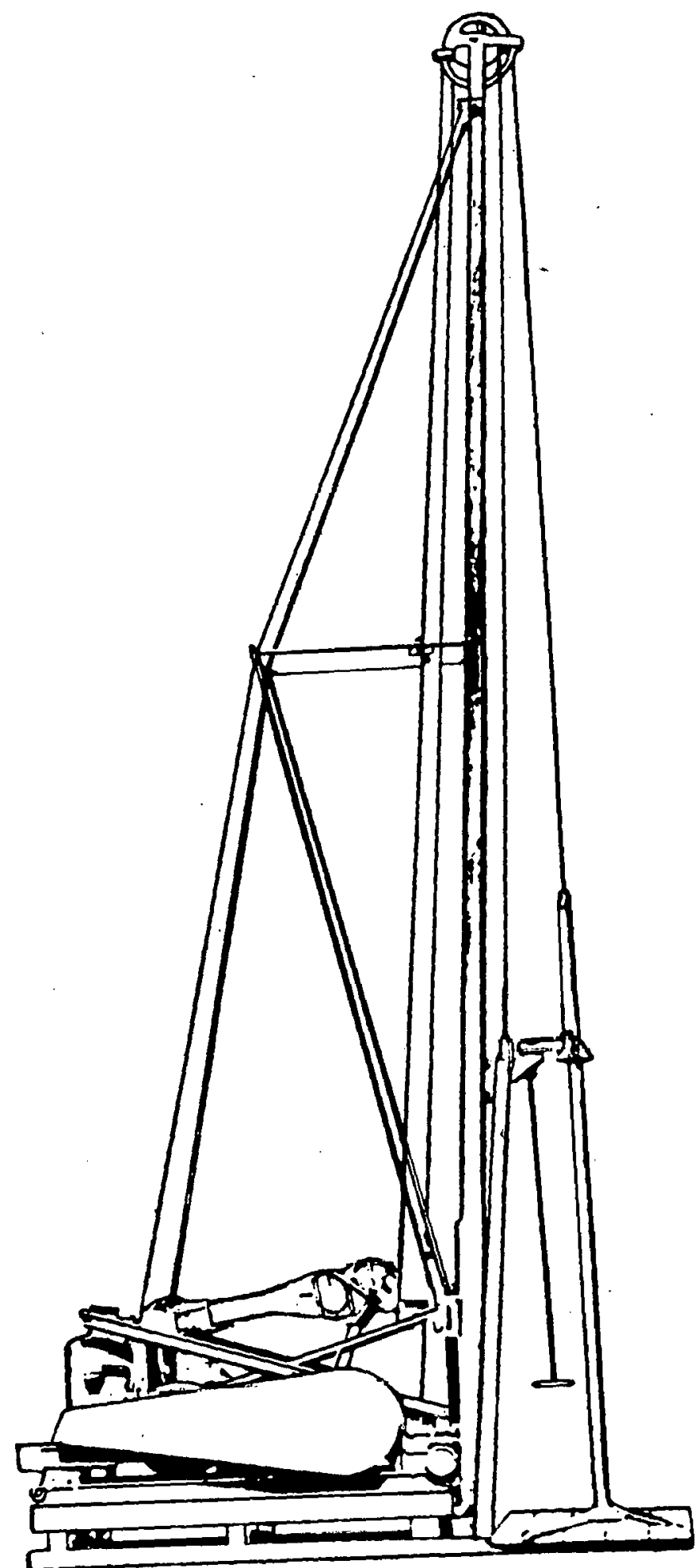

Figure 1. Cable Tool Drilling Rig 
The California stovepipe method is very similar to cable-tool drilling, but differs in three respects: a heavier bailer (or mud scow) is used for simultaneous drilling and bailing, short lengths of laminated steel casing are used rather than standard steel casing, and the casing is pulled downward by hydraulic jacks rather than driven by the impact of tools. Lined-steel casing is suitable for this method since the mechanical. stress to the casing is much less.

Jet drilling is used principally for drilling 76 to 102 $\mathrm{mm}(3-4 \mathrm{in})$ wells to depths of approximately $61 \mathrm{~m}(200 \mathrm{ft})$ that penetrate unconsolidated to very friable formations. Water is pumped under pressure through the drill pipe and out the drill bit. The water then flows upward in the annular space carrying the cuttings in suspension (see Figure 2). The fluid circulation system resembles that of conventional rotary drilling, which is described later. While the water is in circulation, the drill bit is lifted and dropped as in cable-tool drilling, but with shorter strokes. The dropping action of the bit, in conjunction with the washing action of the jet, opens the borehole. The casing is normally sunk as drilling proceeds, which imposes some stress on the casing. Figure 3 illustrates a jet drilling rig.

The hydraulic percussion method, often called the hollow-rod method, is somewhat similar to jet drilling. Water is supplied at the surface to the annular space, and drilling is accomplished by a chopping motion of the bit. A pumping action is produced, and the fluid rises to the top of the drill pipe where it discharges into a settling tank. The casing is driven as the drilling proceeds, so this method is useful only when using steel pipe. Also, it is limited to drilling only small-diameter wells through sand or clay formations.

Rotary bucket drilling, also known as the earth auger method, is used to drill large-diameter shallow wells, primarily in clay formations. This is one of the most common methods used for constructing water wells, but does not have much potential application for geothermal well construction.

The most widely used drilling method is hydraulic rotary drilling. With this method, a borehole is cut with a 


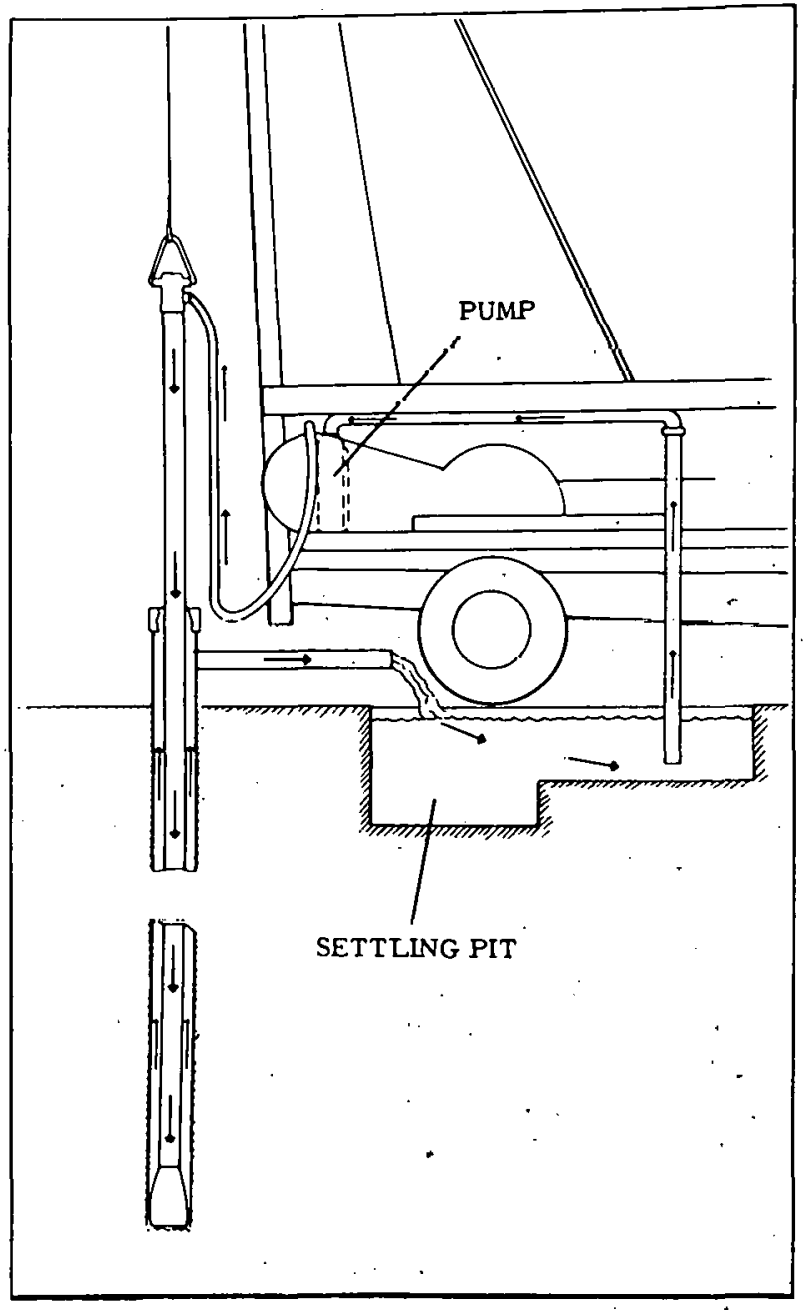

F1gure 2. Fluid Circulation During Jet Drilling

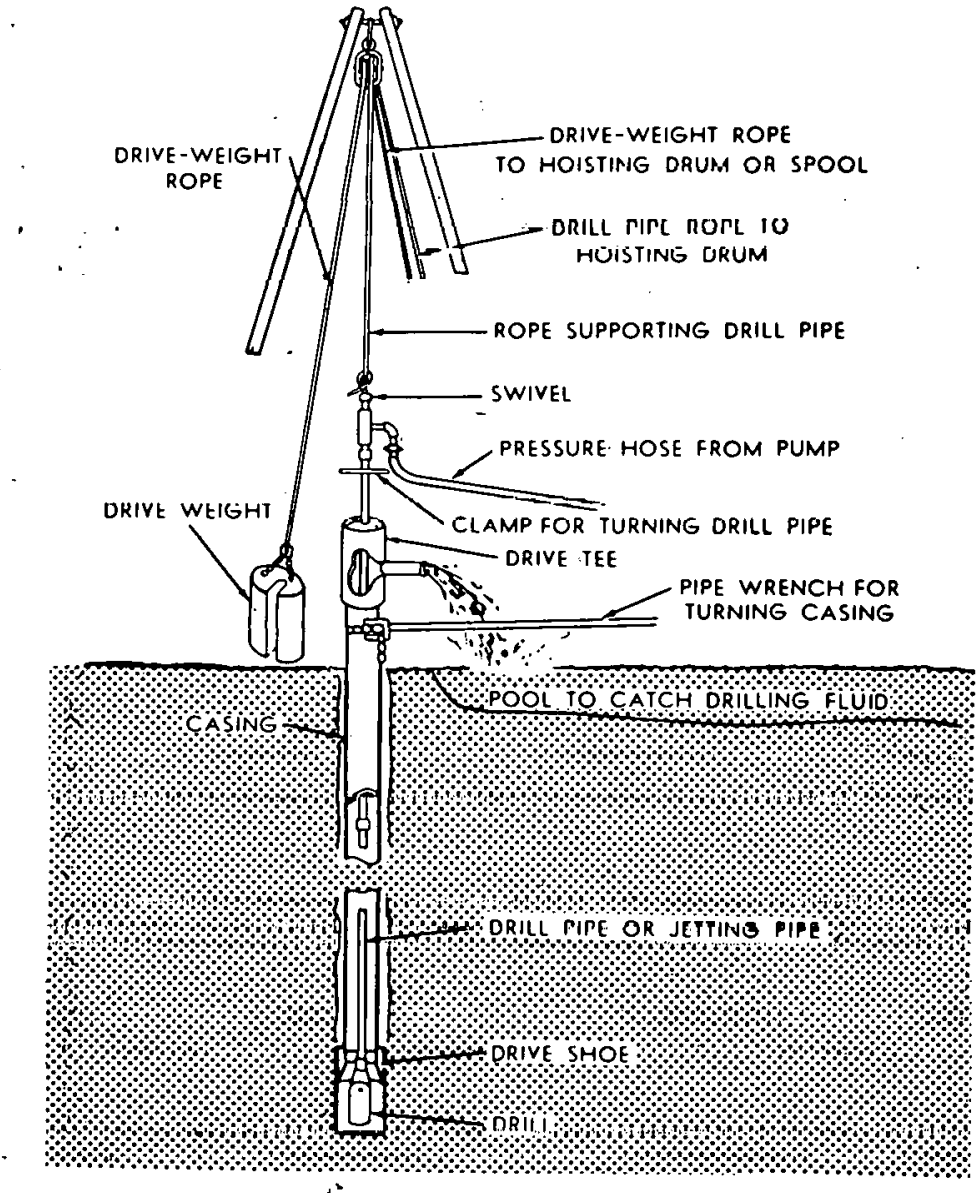

Figure 3. Jet Drilling Rig 


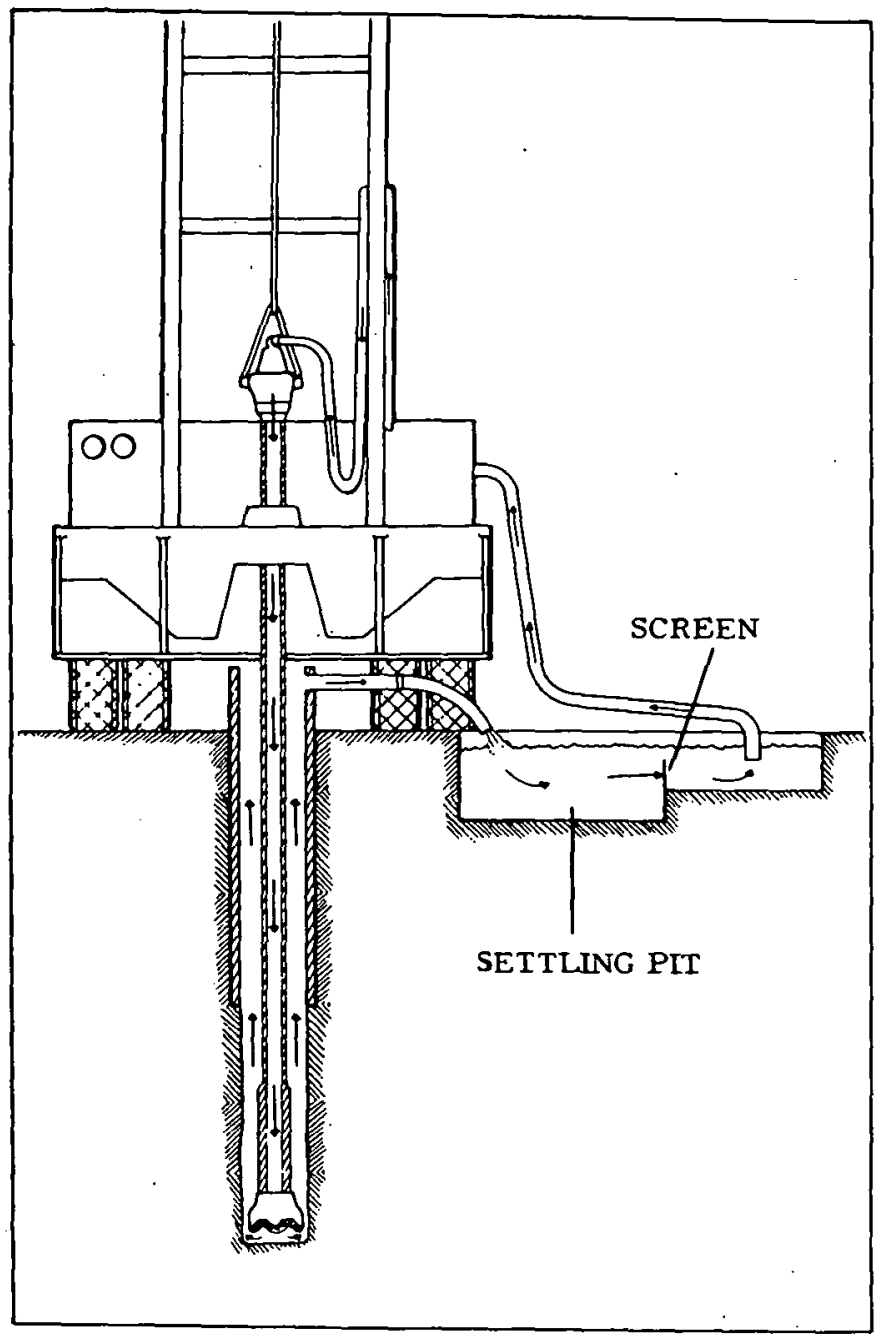

Figure 4. Fluid Circulation During Hydraulic Rotary Drilling 
rotating bit. Drilling fluid or mud is pumped down the drill pipe and out through openings in the bit. The mud then flows upward in the annular space, carrying the cuttings, and is discharged into a settling pit (see

Figure 4). This drilling method can be applied to any type of formation, from soft to very hard rocks. However, above $93^{\circ} \mathrm{C}$ $\left(200^{\circ} \mathrm{F}\right)$ mud should not be used since it tends to bake and clog the formation.

A relatively new method is the air rotary drilling method. In this case, compressed air is used as the drilling fluid, rather than water or mud. Air circulates through the drill pipe, out through the drill bit, and up through the annular space. The high velocity of the air enables it to carry cuttings along with it. This type of drilling is only suited for use in consolidated materials. Machines designed fonr this type of arilling are usually equipped with a conventional mud pump in addition to the air compressor. This enables the driller to use drilling mud while penetrating caving materials above the bedrock. The overburden is then cased and air rutary drilling can proceed.

Reverse circulation rotary drilling is similar to hydraulic rotary drilling, except the flow of drilling fluid is reversed. The drilling fluid is generally characterized as muddy water rather than a drilling mud. Drill cuttings move down the annular space by gravity flow and are pumped upward in the drill pipe to the settling pit. The hydrostatic pressure of the water/drilling flufd column supports the borehole walls, so casing may be set after drilling completion and is not affected by the drilling operation.

Of the eight conventional drilling methods, hydraulic rotary appears to be best suited for constructing geothennal wells with nonmetallic materials. Reverse circulation and air and mud rotary are variations of hydraulic rotary. One advantage these methods offer over other types of drilling procedures is that casing installation and drilling procedures dre lwo sejarate operations. Thus, the mechanical stress imposed upon the casing when these two steps are combined is el iminated. In addition, these methods have greater penetration rates in various geothermal formations. 
Most geothermal wells are drilled with roller bits that contain sealed lubrication systems. During "drilling out" through set surface casing, stabilizers should be used behind the drill bit at intervals along the drill stem to prevent the drill bit from running off center and cutting the casing. Stabilizers should also be used during well workovers when the drill bit is lowered to clean out the bottom of the well.

Reverse circulation is best suited for large-diameter wells that penetrate unconsolidated to very friable formations. The filter cake created by this drilling procedure is less extensive and easy to remove during well development. Conditions which may inhibit this method are (1) a static water level that is close to or above the ground surface, (2) the lack of an adequate water supply to supplement drilling fluid when lost circulation conditions are encountered due to porous-permeable formations, (3) penetration of indurated formations, and (4) encountering a large number of boulders or cobbles whose diameter exceeds that of the inside diameter of the drill stems, causing blockage and preventing fluid circulation.

Air rotary drilling is also capable of drilling small-diameter boreholes. Penetration rates are generally faster than either reverse circulation or mud rotary. Drill cuttings are clean and readily sampled. Using air as the fluid medium virtually el iminates any type of filter cake. A light filter cake is formed when a saturated zone is penetrated using an air rotary drilling rig. 


\section{JOINING METHODS}

Several methods are recommended for joining nonmetallic well casing. However, not every technique can be used with all materials. Only those methods which are compatible with the type of material being used will give satisfactory results. Table 1 lists recommended joining methods for various types of nonmetallic well casing.

\section{A. SOLVENT CEMENTING}

Solvent cementing, often referred to as "solvent velding", is the most widely used method for joining plastic well casing. While the procedure is simple, proper technique is critical to ensure good, strong joints. Solvent. cementing emplnys an adhesive made by dissnlving the plastic in a suitable solvent. When applicd to the plastic well casing, the solvent cement dissolves the pipe surface. This forms a continuous bond between the mating surfaces so that the joined parts become essentially one. It is important that the proper solvent cement be used with the particular materials involved.

Solvent cement socket joints come in two types. One involves a "belled-end" casing section, the other a molded

Table 1

RECOMMENDED METHODS OF JOINING NONMETALLIC WELL CASING

\begin{tabular}{lc}
\hline Material & Joining Methods \\
\hline PVC & $1^{\star}, 2,3$ \\
CPVC & $1^{\star}, 2,3$ \\
ABS & $1^{\star}, 2,3$ \\
SR & $1^{\star}, 2$ \\
RPM & $4^{\star}, 5$ \\
FRP & $1,3,5^{\star}$ \\
Laminated Wood & 6 \\
Asbestos-Cement & 7 \\
Polymer Concrete & $4,3^{+}$ \\
& \\
\hline & \\
2 - Solvent Cement & \\
3 - Thermal Fusion & \\
4 - Bell and Spigot & \\
5 - Quick-Lock & \\
6 - Rivets, Metal Clips or Screws \\
7 - Galvanized Steel Bands \\
$\star$ - Predominant Method Used \\
+ - Has not been used for well casing
\end{tabular}


coupling, which is a separate cylindrical fitting with tapered sockets at both ends. Socket fit is important, and only pipe and coupling casings that give a tight

interference fit should be used since well casing may not properly bind when it is loose in the socket.

Thermoplastic well casing pipe can easily be cut with a fine tooth saw. It should be cut square and all burns removed with a file, knife, or abrasive paper. The surfaces to be cemented should be cleaned, and all traces of moisture removed with a clean, dry cloth. Where necessary, a primer may be used to soften the surfaces to be joined. Using a brush with a width approximately one-half the diameter of the pipe, apply a moderate coat of cement so that only the joining surfaces are covered. The joint should be made as quickly as possible after applying the solvent cement. Insert the pipe into the socket, turning it to ensure even distribution of cement. If the proper amount of cement is applied, a small bead of cement will appear where the ends meet. This excess should be removed because it serves no purpose and may extend the drying period of the cement. The joint should not be disturbed before proper set occurs, or damage to the joint and loss of fit may result.

The use of screws to join collar and belled-end joints have been suggested to permit quicker development of handling strength, thus allowing earlier insertion of the casing into the borehole. However, these screws may eventually corrode and reduce casing strength. Screws should not be used when joining thermoplastic pipe by the solvent cement method.

The solvent-cementing coupling method has several advantages; it is easy to perform and is suitable for any size casing diameter. Also, casing sections can be solvent-cemented together in the horizontal position during drilling operations. The installation of longer casing sections helps reduce construclion drid completion time. A distinct advantage of this coupling method is its field versatility. Casing lengths may be cut and joined in the field to accommodate specific site-related problems.

The joining procedures are relatively simple but must be rigidly adhered to for satisfactory results. Maximum set times and joint strength capable of handling the weight of the casing string can vary considerably. Set times depend on the type of cement used, cenent vicosity, casing diameter, and climatic conditions (temperature, humidity, 
and precipitation), and, therefore, a certain amount of experience and expertise must be aquired by the driller in order to utilize this method. Table 2 lists recommended set times for various temperature ranges and casing diameters.

Table 2

Recommended Solvent Cement Set Times (Hours)

For Maximum Joint Strength

Temperature Range During Initial Set Time

$\begin{array}{rr}{ }^{\circ} \mathrm{C} & { }^{\circ} \mathrm{F} \\ 16 \text { to } 38 & 60 \text { to } 100 \\ 4 \text { to } 16 & 39 \text { to } 60 \\ -18 \text { to } 4 & 0 \text { to } 39\end{array}$

Pipe Sizes

$\begin{array}{cc}51-76 \mathrm{~mm} & 89-305 \mathrm{~mm} \\ 1 / 2 \text { hour } & 1 \text { hour } \\ 2 \text { hours } & 4 \text { hours } \\ 6 \text { hours } & 12 \text { hours }\end{array}$

Note: Most contractors report the use of very short. set times. Usually two to seven minutes allows the casing sufficient time to bond prior to installation. However, such set times are based on the contractor's own experiences with various products and conditions in their working areas.

\section{THERMAL FUSION}

Another method of joining thermoplastic well casing is heat or thermal fusion. This method is especially useful for systems in high-temperature, corrosive environments. There are two methods of thermal fusion: butt fusion and socket fusion. Dutt fusion is used on all sizcs of casing, although it is of greater importance to larger diameter casing. With this method, casing ends are joined using.a flat hot plate which heats and softens the surfaces to be joined. The plate is removed, and the two softened ends are brought together under pressure and allowed to cool.

Socket fusion involves the joining of casing to fittings sockets using heated male and female elements. The temale heated face fits outside the thermoplastic casing, while the male heated element fits into the fittings socket. The elemenls dre lieated to $265^{\circ}$ to $293^{\circ} \mathrm{C}\left(509^{\circ}\right.$ to $\left.559^{\circ} \mathrm{F}\right)$, depending on the type of thermoplastic involved. At these temperatures, the surfaces to be joined are melted to form a homogeneous unit. Once the heating time elapses, the elements are removed and the two parts are quickly brought together without Lurniny. 
They are held in proper alignment for a period of time equal to the heating period. Socket fusion is generally used with smaller diameter casings, and a separate set of tools is necessary for each pipe size required. In weather below $4^{\circ} \mathrm{C}$ $\left(39^{\circ} \mathrm{F}\right)$, the fusion time must be increased. A test joint should be made and cut apart to be sure it is properly fused.

\section{THREADING}

The most common method of mechanical joining of thermoplastic well casing involves threaded connections. Molded threads on plastic pipes of Schedule 40 dimensions or cut threads on pipes of Schedule 80 or greater thickness are available. Plastic well casing can be cut with conventional pipe threading tools used for metal pipes. The pressure rating of threaded thermoplastic well casing should be reduced to one-half that of the unthreaded casing. Molded or formed threads should be used only with the lubricant sealant specifically recommended for the thermoplastic material in use. Care must be taken not to overtighten the joint, for this may cause structural failure of the joint. Generally, tightening with a strap wrench (not to exceed 60 percent of one full turn) is adequate.

Cross-threading should be avoided when using threaded joints. Molded threads are generally specified because their better design decreases cross-threading and misal ignment. Threaded joints are sometimes damaged and hard to remove. If damaged, the joints can easily be replaced. For glued joints, the pipe or joint must be sawed through and a new joint required upon reinstallation.

Thermoplastic casing may also be attached to metallic screens through adapters or threaded casing sections. A plast ic coupling adapter is solvent-cemented to the plastic casing using the procedures listed previously. A metallic screen can then be screwed into the adapter. The contractor should make sure that the plastic threads match the thread dimensions of the metallic screen. Extreme. care must be exercised while threading the metallic screen to the plastic adaptor or casing. The metallic threads will easily cut and damage the plastic threads if the two sections are cross-threaded. It is recommended that a plast ic male thread be joined to a metal female thread. Since the two materials have different coefficients of expansion, the male plastic fitting will become tighter within the female metal fitting when expansion occurs. 
V. QUICK-LOCK JOINT

The quick-lock or key joint employs specially designed bell and socket or straight end and collar assemblies. A flexible locking strand is forcefully inserted into precut grooves which locks the two sections into one. Additional grooves may accommodate gaskets that ensure a watertight seal. This joining method is fast, easy to perform, and requires no specialized labor skill. If the well components are pulled and disassembled, the key joint is advantageous because the ring is removed and the pipe easily

disconnected. Figure 5 depicts this type of method.

\section{BELL AND SPIGOT}

The bell and spigot joining method (Figure 6) is almost exclusively used for polymer concrete and RPM casing. The bell end is oriented skyward and the spigot end oriented earthward when the two pieces are coupled. The bottom casing section is supported by an inner flanged pipe. Compressive forces serve to keep the casing sections coupled together as the casing string is installed into the borehole. A rubber gasket can be used in conjunction with this coupling method to ensure a watertight seal. The distinct advantage of this method is that it is virtually impossible to separate the coupled sections once the casing string has been lowered into the borehole. However, this type of casing and coupling method is restricted to shallow depths, generally less than $305 \mathrm{~m}(1000 \mathrm{ft})$, and to temperatures bel ow $66^{\circ} \mathrm{C}\left(151^{\circ} \mathrm{F}\right)$.

\section{RIVETS/METAL CLIPS COUPLING METHOD}

Rivets and/or metal clips are extensively used to couple a relatively new type of casing fabricated from specially treated presswood. The casing is assembed from two or three shells into a final tubular product. Figure 7 illustrates the two basic coupling methods for this type of casing. Each shell section has noncorroding rubber joints on the longitudinal and horizontal flanges that resist aging; the screen sections have these joints on the horizontal flanges only. The longitudinal flanges of each shell section have grooves and tongs that counteract vertical forces. The shell sections are staggered during the assembly process which increases the rigidity of the final tubular product. The three-shell casing is coupled with copper rivets while the two-shell casing is held together with metal clips or clamps. The copper rivets require that riveting tongs be used. A special clamping device is utilized with metal clips. Ideally, this type of casing can be assembled by one man at a rate of $61 \mathrm{~m}(200 \mathrm{ft})$ per hour. 

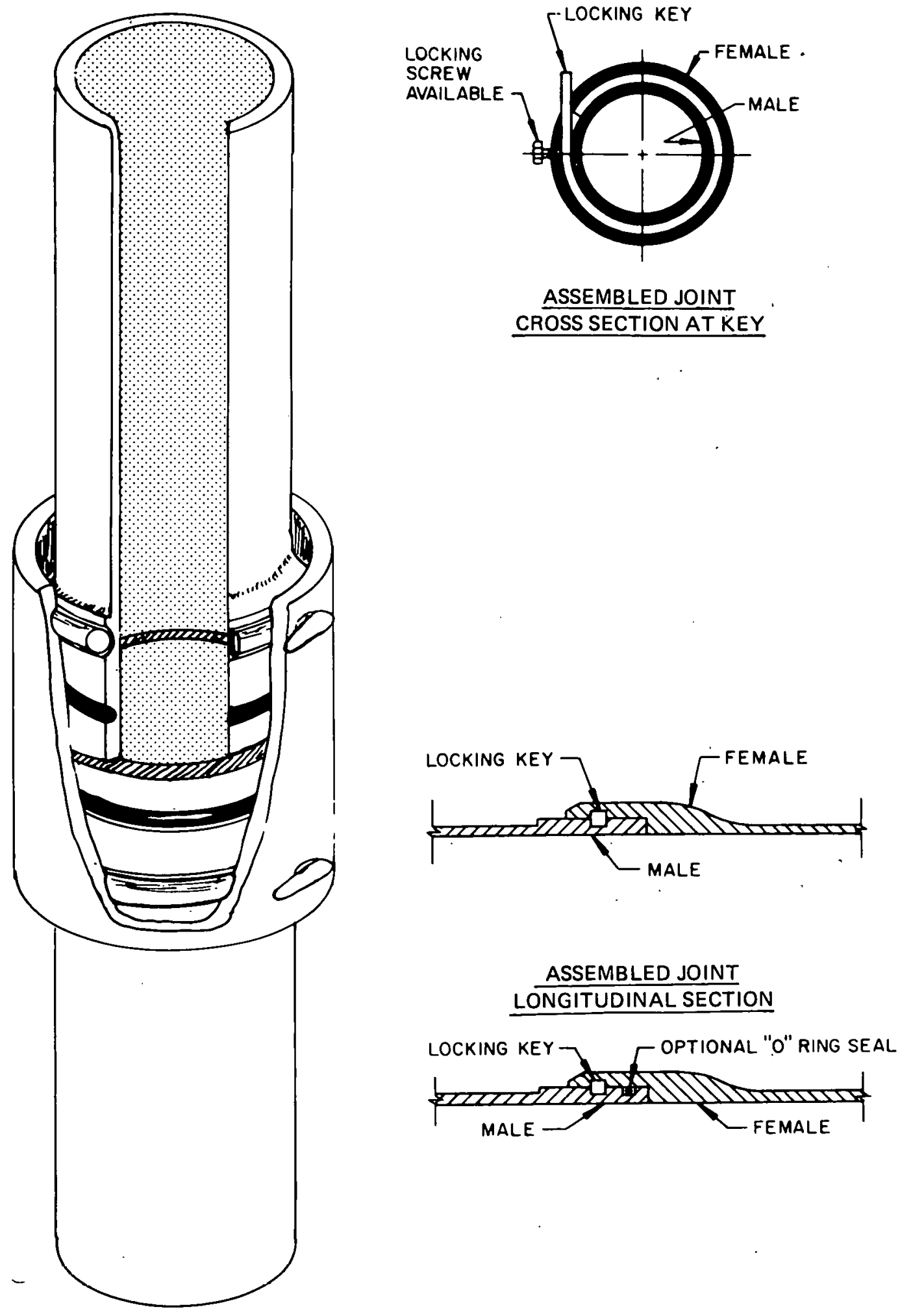

Figure 5. Quick-lock Joint 


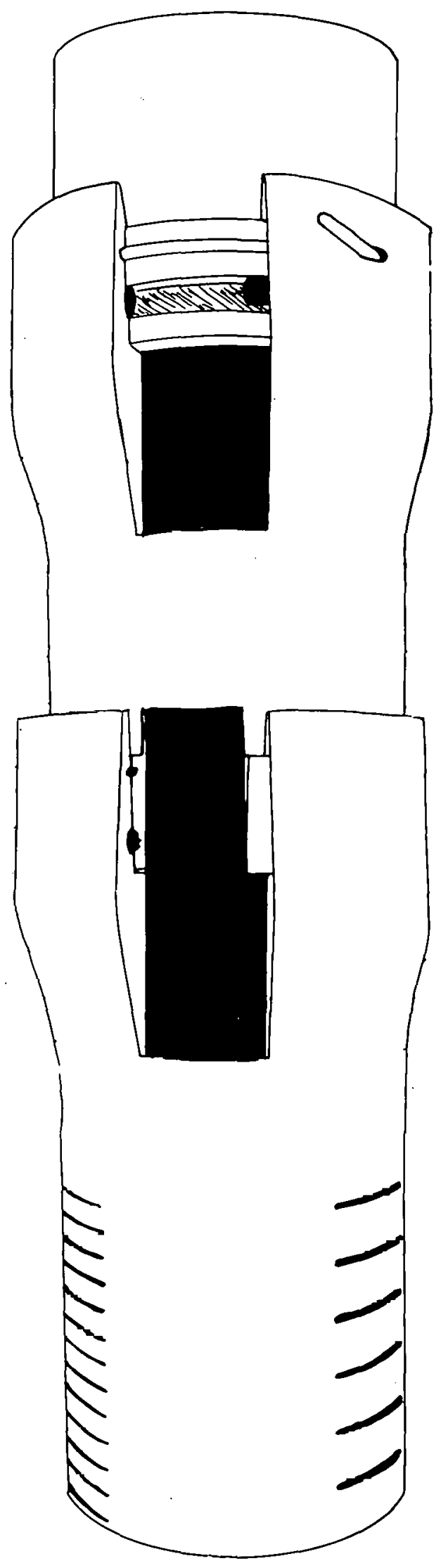

Figure 6. Bell and Spigot Joint 

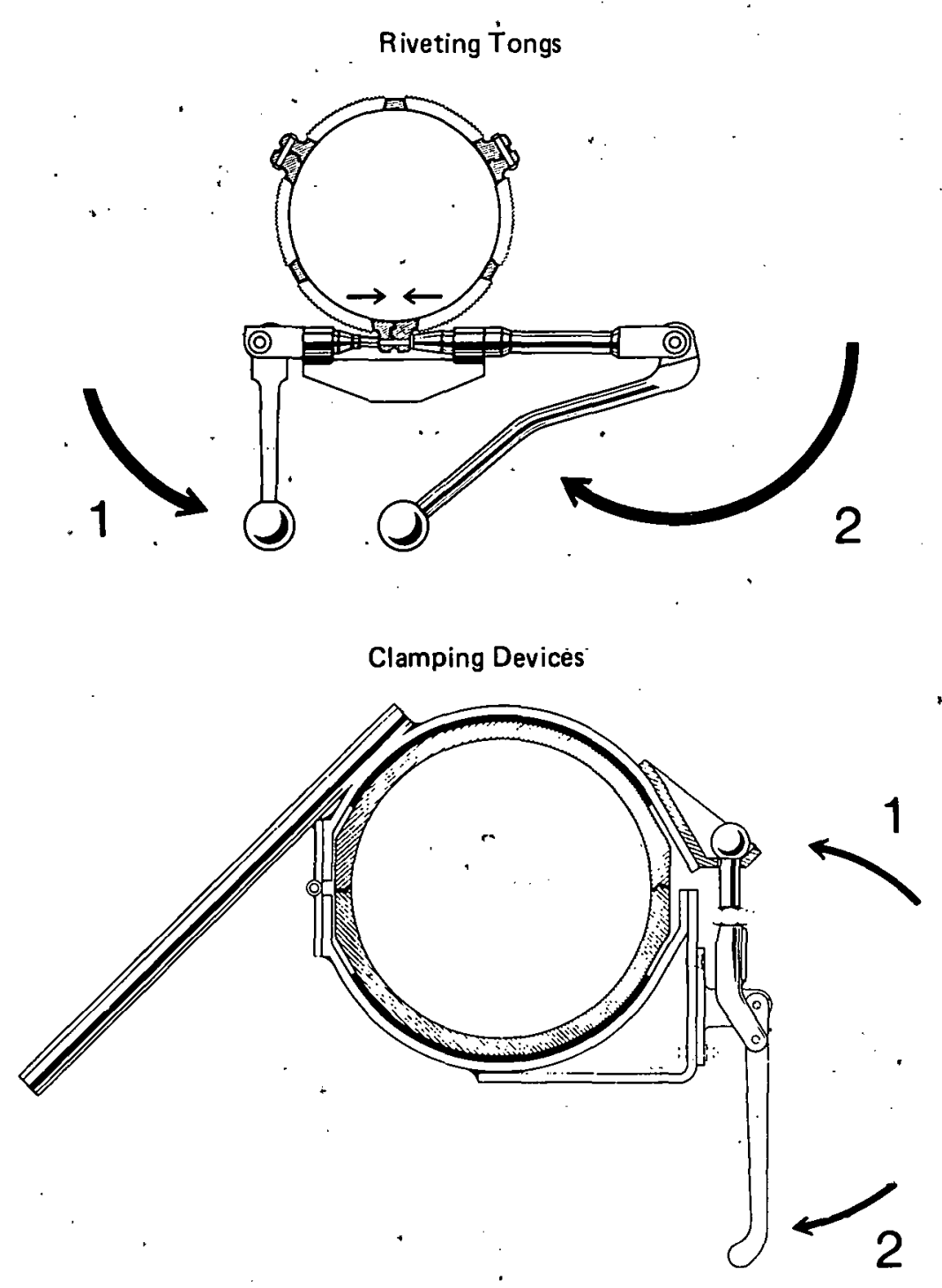

Figure 7. Joining Methods for Wood Casing

$-91-$ 


\section{METHODS OF CASING AND SCREEN INSTALLATION}

Because of the light weight of most nonmetallic casing, less expensive equipment can be used to install it. When being lowered into a well, the low specific gravity of nonmetallic casing causes the casing string to be only slightly heavier than the water it displaces. This greatly facilitates clamping and holding of the pipe during installation. Generally, little or no special equipment (e.g. a hoist) is required to install nonmetallic casing. Since some thermoplastics become very brittle when cold, and could break during handling and installation, special care should be taken to avoid impacts or loading during winter.

Nonmetallic water wèll casing and screen can be installed in any type of borehole. However, installation methods and accessory equipment differ according to the drilling method. The installation techniques best suited for particular drilling methods are outlined below.

A. Well Casing Installation Methods for Rotary-Drilled Boreholes in Unconsolidated Materials.

Several techniques are satisfactory for installing nonmetallic well casing and screens into unconsolidated aquifers.

One method involves capping the end of the screen or casing and filling the entire casing with water or drilling mud. This works best if the drilling mud is heavy enough to prevent any of the surrounding formation materials from filling the borehole. The end of the screen can be capped, then the screen and casing should be filled with water to reduce the casing string's buoyancy and to eliminate the pressure differential exerted by the water and/or drilling fluid on the outside of the empty casing. The screen and casing are. then lowered into the borehole.

Commonly, several lengths of casing are joined together to form $12-\mathrm{m}$ (40 ft) sections. This enables greater lengths of casing to be installed in a shorter period"of time. The borehole must remain open during the installation procedure (i.e. no sloughing or swelling should occur that would impede the casing's installation into the borehole). When the casing has been successfully placed at the desired depth, clean water is pumped through it to remove any drilling mud that has entered the screen or casing or has impregnated the borehole sides. 
An alternative method of installation may be used when bridging is likely to occur in the borehole. Bridging necessitates a "backwash valve," which is installed in the bottom of the screen (Figure 8). A 25 to 51 mum (1-2 in) galvanized pipe wash line, whose bottom end bears a left-handed thread, is screwed into the backwash valve. Clean water is then pumped through the wash line and valve to provide an upward flow outside the casing that reduces the tendency for bridging.

When this method is used to develop the aquifer, the driller must plug or cap the top of the casing so that the fluid overflows on the outside of the casing, bringing the drilling mud to the surface. If the casing is not capped, the drilling mud will seek the path of least resistance and enter the screen.

After the well has been successfully developed, the casing and borehole must be kept full of water. Circulation of water during emplacement of the gravel pack will prevent bridging and reduce the possibility of damage to the well screen from the sudden collapse of bridged gravel. Maintaining water in the borehole will also reduce the possibility of cavities forming around the screen. These cavities, once formed, can fill with clay or grout as the upper annulus is sealed.

Cement, clay, or clean native materials are used to fill the annular space (i.e. that space which exists between the outside wall of the casing and the borehole wall). The contractor should check with the appropriate state regulatory agency to ensure that clay or an appropriate substitute can be used. The annular space must be sealed with cement grout where it penetrates shallow aquifers. clay can be used as a backfill material to within $6.1 \mathrm{~m}$ (20 $\mathrm{ft}$ ) of the surface in the absence of shallow aquifers. Cement grout should then be used to form a well seal to the surface or at least to the frost line.

Clay is not suitable as a backfill material under the following conditions:

1. When the clay sealants will make contact with the aquifers;

2. When structural strength or stability of the sealant is required;

3. When the sealant may dry out; 


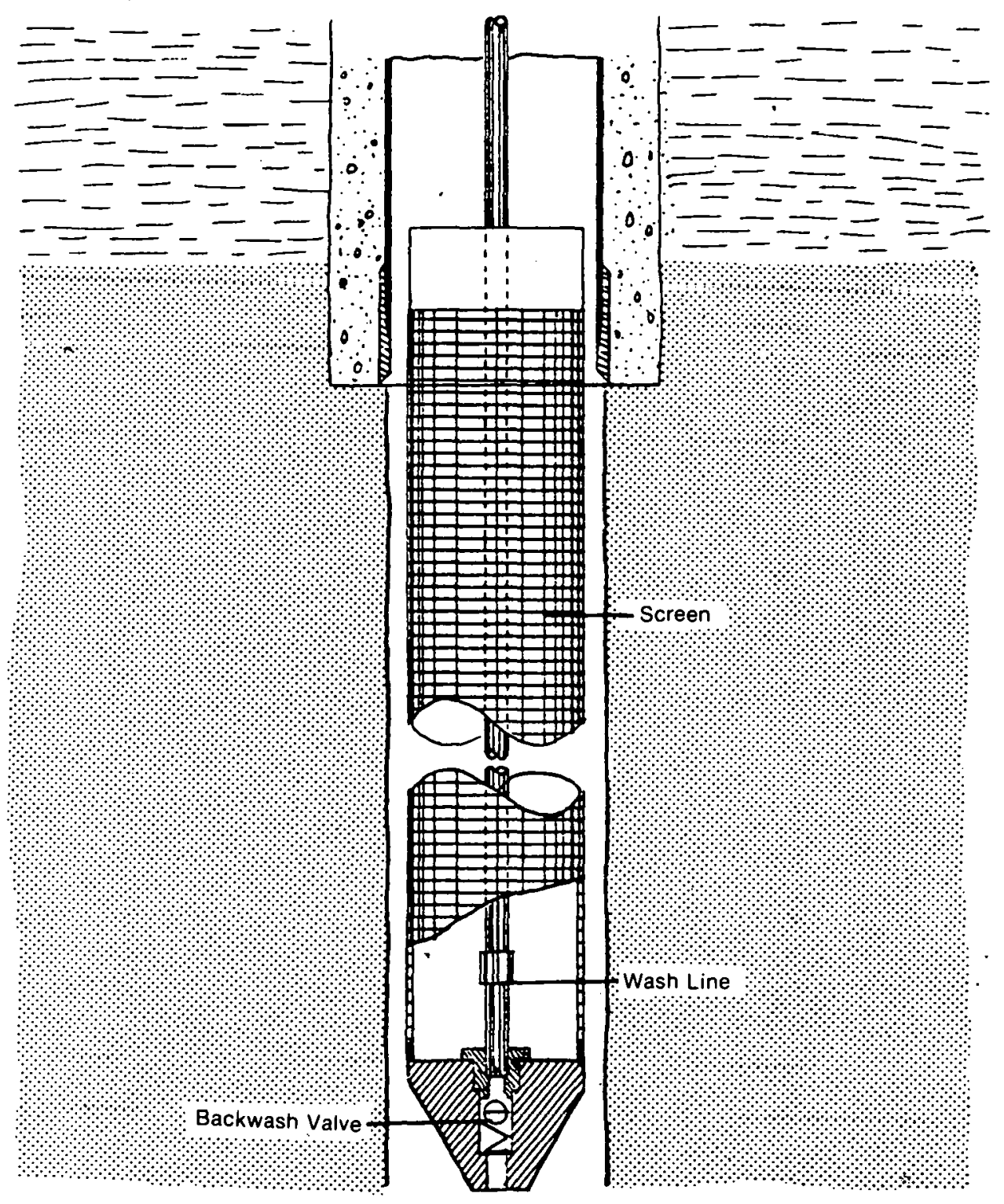

Figure 8. Backwagh Valve 
4. When flowing water may degrade or erode the sealant.

B. Installation of Well Casing in Rotary-Drilled Boreholes in Consolidated Materials.

In this case, the borehole must provide approximately 38 to $51 \mathrm{~mm}(1.5-2 \mathrm{in})$ of annular space around the casing. At least $1.52 \mathrm{~m}(5 \mathrm{ft})$ of the borehole must penetrate the formation into which the well casing will be set. After the borehole is properly drilled, installation of casing can begin.

Because nonmetallic casing cannot be driven into rock, the contractor must use a formation packer to form the bottom seal. Once the formation packer has been attached to the bottom of the casing and the casing string has been lowered into the borehole, the bottom seal material is introduced into the annular space. This sealant may consist of puddled clay, neat cement. or a combination of both. The contractor should use enough sealant to fill the annular space to at least $7.62 \mathrm{~m}(25 \mathrm{ft})$ above the bottom of the casing (Figure 9 ).

When the bottom seal has been completed, intermediate filling can proceed. Intermediate fill can consist of rock cuttings, puddled clay, or bentonite. The intermediate fill should extend to within $6.1 \mathrm{~m}(20 \mathrm{ft})$ of the surface. The surface seal is then added (as explained previously) to complete the filling process. Surface sealant usually consists of the same material used to form the bottom seal.

Control of the rate of backfilling cannot be overstressed. Fill materials should be placed in the annular space at a slow, even rate. The adverse effects of bridging can usually be avoided when the annular space is filled in this manner.

C. Installation of Nonmetallic Water Well Casing Using a Cable Tool Rig.

Because nonmetallic well casing is not designed to be driven, the extent to which it can be installed with a cable tool rig is limited. However, nonmetallic casing can be set using the pull-back method when a cable tool rig is used to drill the well. The pull-back method is essentially identical to cable-tool drilling methods when steel casing is used. Steel casing is driven into the chosen aquifer 


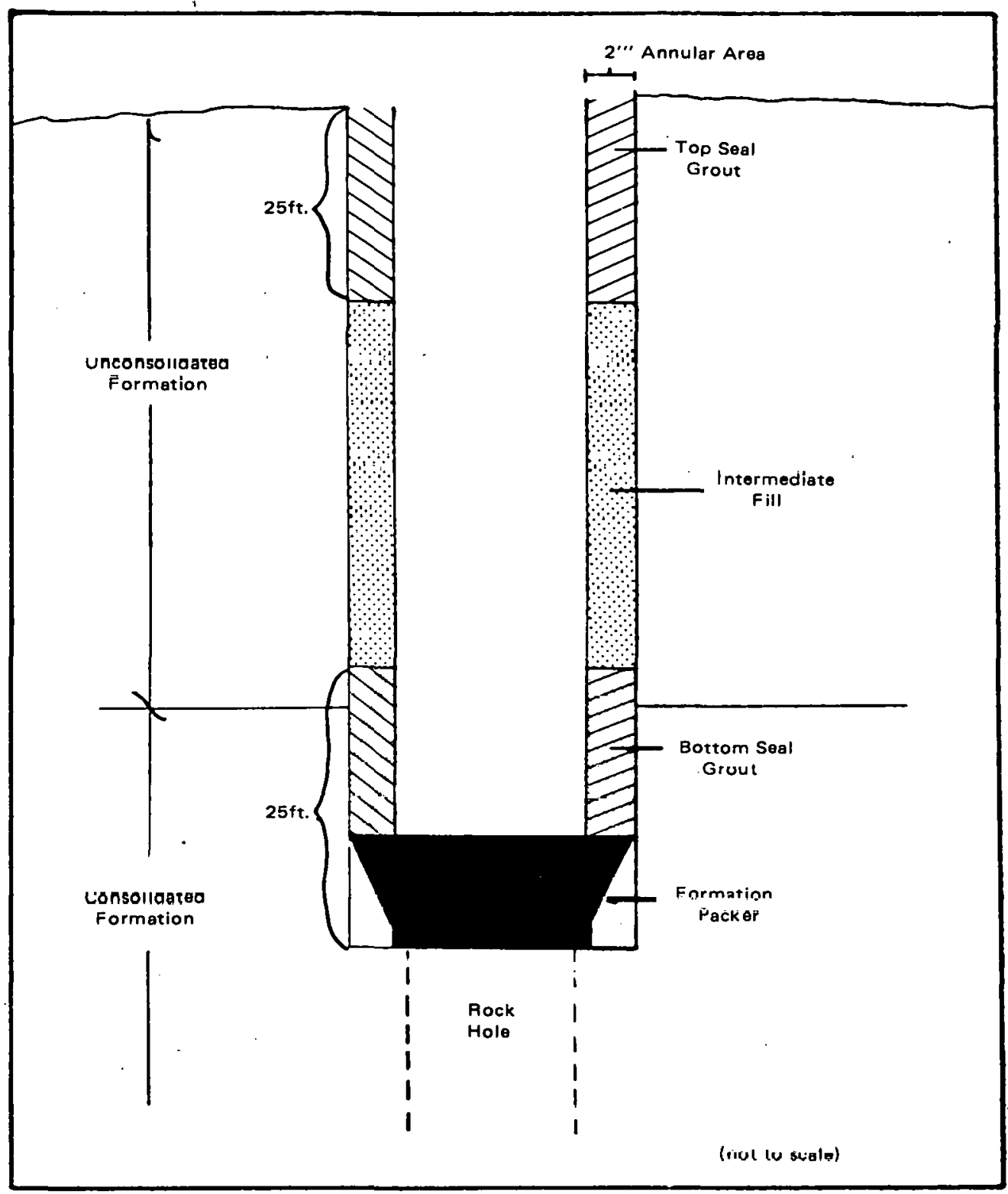

Figure 9. Cross-section Illustrating the Position of Intermediate Fill and Grout 
using standard procedures. The nonmetallic casing is then inserted into the steel-cased well bore. The nonmetallic casing is filled with water to ensure that it does not float. The contractor then jacks the steel casing out of the borehole for later use. Backfilling or grouting operations are emplaced after the outer steel casing is withdrawn.

Formation packers are used to seal the screen in an open-hole installation. When the pull-back method of water well screen setting is used, the formation packer is mounted on a galvanized steel nipple (optional) which is threaded onto the screen. After the screen is lowered into place (open-hole installation) or the casing has been pulled back to expose the screen (pull-back method), the packer is expanded by applying gentle pressure with a properly-sized swedging tool. (Figure 10).

I I. WELL CEMENTING

\section{A. Heat of Hydration}

Under ordinary circumstances (temperature and depth), the effectiveness of grouting materials for sealing wells is adequate. Certain situations, however, require that caution be used when grouting wells cased with nonmetallic materials. When Portland cement-based grouts cure, a by-product of the process is the heat of hydration which causes increased temperatures in the vicinity of the casing. This may result in deformation and collapse of the casing, depending on the heat resistance of the casing material and the temperature of the geothermal fluid.

Peak temperatures and the duration of such temperatures produced from the heat of hydration are directly related to the type and amount of grout used. In a recent study at Auburn University 51 , a Type I Portland cement neat slurry grout was found to produce a higher peak temperature than a similar mix containing 2 percent calcium chloride. For nominal $38 \mathrm{~mm}$ (1.5 in) grout thickness, a temperature increase of $9.4^{\circ}$ to $14.4^{\circ} \mathrm{C}\left(17^{\circ}\right.$ to $\left.26^{\circ} \mathrm{F}\right)$. was achieved. With a $92 \mathrm{~mm}$ (3.6 in) grout thickness, peak temperature increased to $37.2^{\circ} \mathrm{C}\left(67^{\circ} \mathrm{F}\right)$. Thus, where thick grout envelopes occur as a result of caving within the borehole, temperature increases on the order of $94.4^{\circ}$ to $105.6^{\circ} \mathrm{C}\left(170^{\circ}\right.$ to $190^{\circ} \mathrm{F}$ ) can be expected. Peak temperatures were reached 8-10 hours after water was added to the cement. Casing 


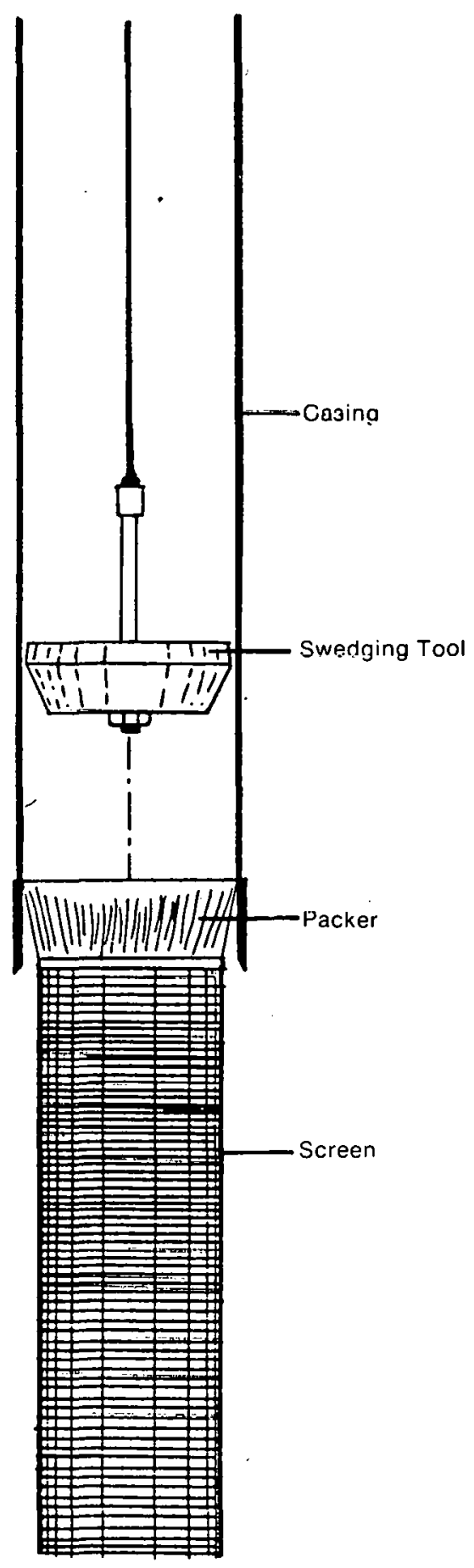

Figure 10. Pull-back Method 
temperatures remained near their peak temperatures for several hours before returning to the original temperature.

As the casing size increases, for a constant grout thickness, the ratio of the grout/soil interface surface area to the grout volume tends to decrease and the ratio of grout/casing interface area to grout volume increases. Because of this geometric relationship and the fact that the specific heat of water is much higher than that of air, smaller diameter casing filled with water would tend to have higher temperatures than the larger diameter casing. However, for a given size casing, the water would lower the peak temperature at the grout/casing interface.

Several steps can be taken to reduce temperature rises produced when grout sets up and hardens. Obviously, the type of grout and its associated heat of hydration is of primary concern. Quick-drying grout is not recommended for use in wells cased with most nonmetallic materials because the quick-drying process releases a great deal of heat during a short period of time. Both the heat and its rate of generation have adverse effects on the casing.

When grout contains little or no bentonite, it hardens in a manner similar to quick-drying cement because it is heavily concentrated. When bentonite is added to the grout, its curing time increases. This reduces the rate at which heat is generated during the setting of the cement. The contractor should, therefore, be sure to mix at least some bentonite into the grout mixture to be used in wells cased with nonmetallic materials. Most grout manufacturers list the amounts of bentonite ( 2 to 9 percent by weight) added to the grout.

When the annular space exceeds $102 \mathrm{~mm}$ (4 in), the grout tends to insulate itself, preventing the heat from dissipating to the surrounding earth materials. As the heat accumulates in the grout jacket, it may cause structural damage to the casing as described above. To minimize the hazards of this heat build-up, the well should be designed so that the size of the annular space meets minimum State or recommended EPA requirements.

Temperature can also be reduced by circulating water through the casing. On the other hand, with an air-filled casing, the temperature of the casing, soil, or grout envelope will rise since air is a poor conductor of heat. 
The emplacement of the grout also affects the strength and stiffness of the casing. In general, little or no tendency to collapse will be exhibited if the grout is emplaced using the Haliburton or some similar method. 40 Heat-induced collapse of the casing, however, is more likely to occur where the grout is emplaced around an air-filled casing from the top down.

Although grouting rarely creates a problem during well construc:ion, it may cause potential problems. In summation, potential problems can be avoided by following these steps:

1. Select the correct type of cement.

2. Add bentonite (or some other suitable retardant) to reduce the rate of the exothermic rcaction produced by curing of the qrout.

3. Keej the annular space to the minimum specifications given in state construction codes or in U.S. EPA's Manual of Water Well Construction Practices.

4. Select the appropriate method of grout emplacement and control the rate at which the grout is placed in the annular space.

5. Circulate water through the casing to carry away the heat produced by hydration of-the grout.

B. Cement/Casing Adherence

Fiberglass casing has been used in a doublet well supplying $60^{\circ} \mathrm{C}\left(140^{\circ} \mathrm{F}\right)$ water for a district heating system in Paris 36 . Prior to selecting this type of casing, cement adherence tests were performed. The cement lised was Cemoil Class G prepared according to API standards without an accelerator. Prehydrated bentonite was used to obtain 1.7 and 1.85 specific gravity mixes.

The cement/casing adherence was measured after 24 hours using a hydraulic pressure testing device. Results indicated that cement adherence for flberglass cas Iny was higher than for steel casing. In addition, coating of the outer surface of the fiberglass with sand or gravel was not necessary if the specific gravity of the cement mix was 1.85. 
Since fiberglass casing has the smoothest outer surface of all nonmetallic casings, it is expected that other types of nonmetallic casings will have equal or greater cement/casing adherence.

\section{WELL DEVELOPMENT}

Well development refers to the steps taken to remove fine material from the aquifer caused by drilling, or to increase the permeability near the well bore by enlarging and creating passages in the rock. Development work brings the yield of the well to its maximum capacity. Well development is an essential part of well construction.

Every well drilling method reduces the aquifer's permeability in the immediate vicinity of the borehole walls. The extent of damage depends on the drilling method and the material comprising the formation. Conventional rotary methods circulate a mud fluid which forms a filter cake on the face of the borehole and partially invades the formation. Air rotary methods blow fine particles into the formation which reduce the porosity. Driving casing in the cable-tool method vibrates the sand around the casing pipe and packs the sand more tightly together, reducing the porosity. Working the pipe down through the water-bearing formation by bailing methods reduces vibration due to the driving and retains permeability.

Proper well development results in many benefits. It corrects any temporary damage to the water-bearing formation caused by drilling, and it increases the permeability of the formation in the vicinity of the well. When the water-bearing zone is unconsolidated, sand near the screen will be stabilized so that the well will yield sand-free water.

The primary methods of well development used by the water well industry are surging, jetting, fracturing, and acid treatment. The mechanical surging method is the easiest and most widely used technique. This method uses either compressed air or highly pressurized water and a plunging device to force fine particles from the formation. High-velocity jetting is generally the most effective development method. In this method, water is forced at high velocities through a nozzle positioned in the well. Fracturing methods utilize high pressure fluids, propping agents, and explosives to widen existing fractures and 
produce new ones. Acid treatment is most common in carbonate aquifers. Strong acids dissolve the aquifer material to increase channel size, thus increasing well yield.

\section{A. Surging}

Mechanical surging forces water into the water-bearing formation and then withdraws it rapidly, pulling fine particles into the well. This is accomplished by driving a plunger up and down in the well like a piston in a cylinder. (Figure 11). Normally, a special tool called a surge plunger or surge block is used, but a heavy bailer will suffice.

Two types of plungers are commonly employed in water surqinq: a solid-type surge plunger dild a valve-type surge plunger. The valve-type plunger has a number of ports which allow water to pass through the plunger during the downstroke, thereby reducing its force. The solid-type does not have these passages. It is usually best to begin with a light surging action which increases as development progresses. The ports can then be plugged to enable full surging action.

Surging can also use compressed air as the development tool. As the air is fed into the casing, it reduces the specific gravity of the drilling mud and causes it to rise out of the well. However, this change in the material's specific gravity inside the casing upsets the pressure balance between the interior and exterior of the well. This pressure differential may exceed the resistance of the inaterial in cases wherc the cxtcrnal support may be incomplete or inadequate. The greater the rate of air injection into the casing, the greater the pressure differential. The introduction and "shooting off" of the air must be done in a controlled manner so that excessive pressures do not develop. Fine particles are removed by a montified air-lift method in which water is drawn from the formation at a given level of the well screen. A period of air-lift pumping is followed by a short burst of air which reverses the water flow in the formation. An air compressor eductor (pumping) pipe, flexible bore, and relief valve are required equipment. This method is well accepted among drillers using nonmetallic casing. 


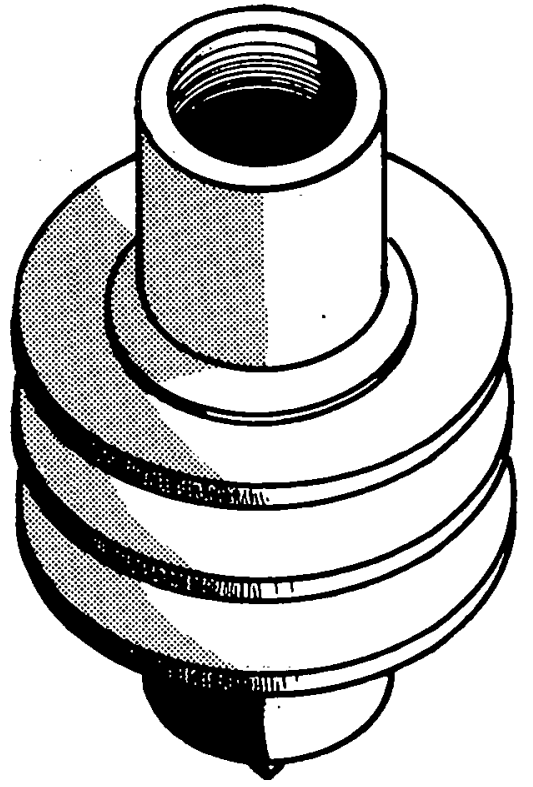

Typical solid-type surge plunger

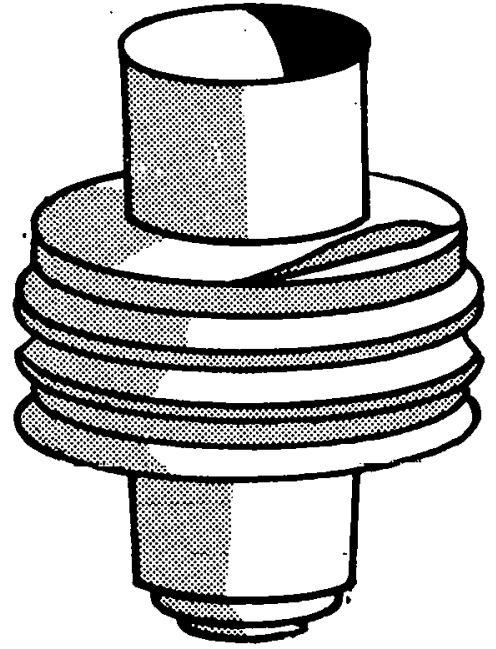

Typical, valve-type surge plunger

Figure 11. 
The pump-surge procedure varies to suit each well. Because there is no established routine, a driller must have practical experience when surging by this method.

\section{B. Jetting}

High-velocity jetting is an effective method of well development. Since energy focuses on a small area of the well screen, maximum results are achieved. The jetting tool is a nozzle mounted at the end of a pipe which can be selectively positioned in the well. If the well screen openings are closely spaced and correctly shaped so the jet stream can be directed out into the fomation, agitation will result during development and it will rearrange the formation particles surrounding the screen (Figure 12). In addition, the mud skin deposited on the borehole in the conventional rotary drilling method disperses ș fiatr. The mud and clay particles cdal edsily be pumped out. Thus, by slowly rotating and raising the jetting tool, the entire screen can be effectively developed.

C. Fracturing

Fracturing techniques were originally developed by the petroleum industry and were later found to be successful in water well drilling. Fracturing is any method designed to create or enlarge fractures in the water-bearing formation to increase well yield. Fracturing treatment is beneficial when:

1. It will el iminate formation damage due to the "skin effect" of drilling mud or the swelling of clays. Since damage is limited to the immediate vicinity of the well bore, only a mild treatment is necessary.

2. The aquifer is composed of homogeneous rock of low permeability. Fracturing has the same effect as increasing the size of the borehole; water which formerly flowed through the low-permeable rock is able to move into the high-capacity fracture to the well.

3. Fractures radiate from the well bore and connect permeable and porous systems that may otherwise be isolated from the well by impermeable barriers. 


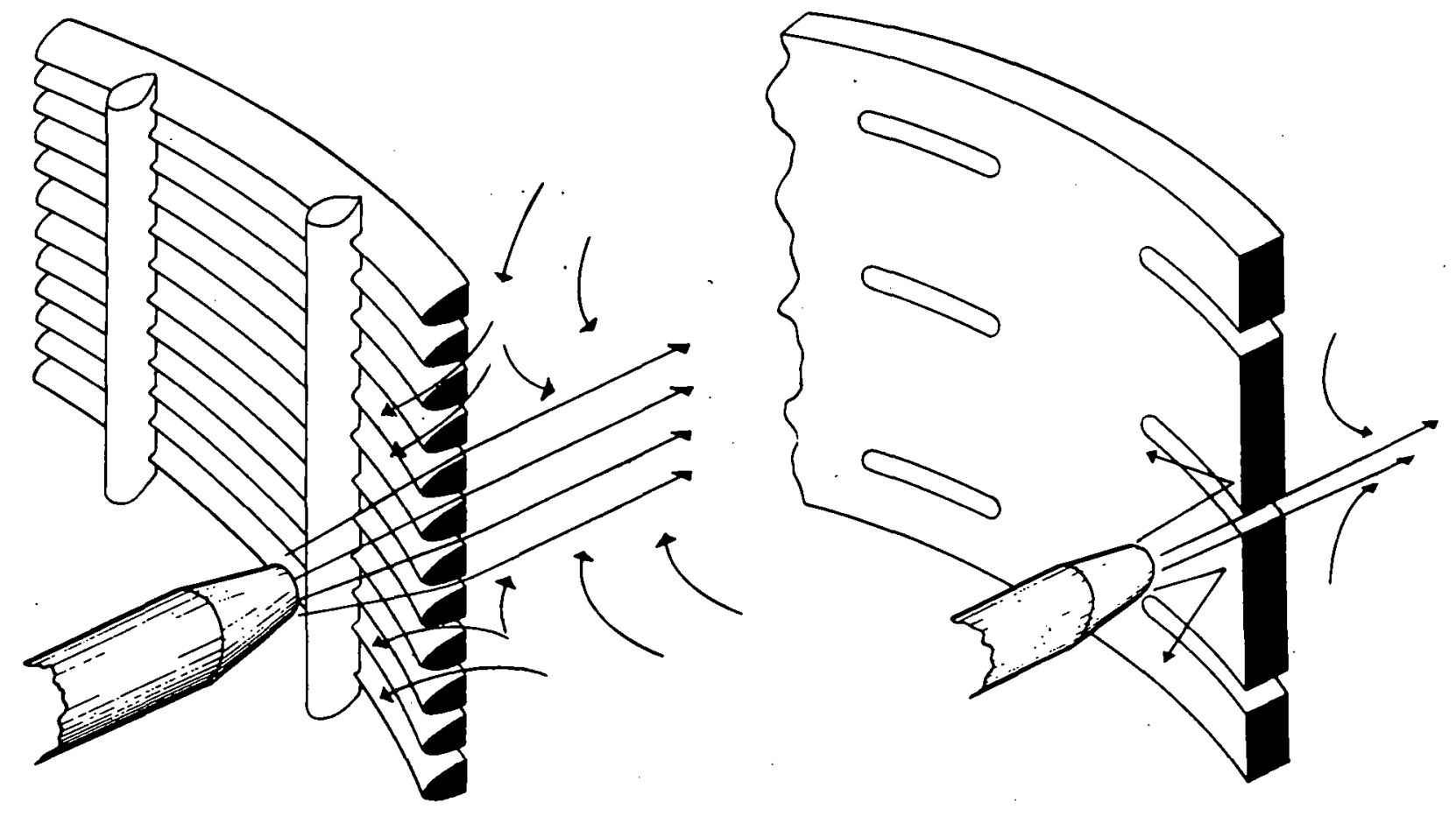

Figure 12. Jetting Method 
Two primary methods of fracturing are practiced: hydraulic fracturing using a fluid under high pressure, and shot fracturing using explosives. Hydraulic fracturing is more complex and more expensive than explosives, but provides greater control and slightly better long-term results. Fractures are produced by breaking down the water-bearing formation hydraulically with a sand-carrying fluid. Fracturing is usually employed after some type of prel iminary development. Sand is used to prop the resulting fracture. This method requires high pressures which necessitate special equipment.

On the other hand, explosives are easy to use. Charges vary from 13.6 to over $227 \mathrm{~kg}$ (30 to over 500 pounds), depending on the hardness of the rock and the depth at which it is to be detonated. There is no established method for detcrmining the size of the charge or predicting the results, so the driller must rely on his experience. This method is generally not recommended for nonmetallic casing. However, ABS well casling call withstand explosive development due to its high impact strength.

D. Acidizing

Strong acids have been used longer and more often than any other chemical in the construction of wells. They are a popular well development tool when carbonate aquifers are encountered, and are being used more frequently as a well rehabilitation tool for any aquifer material. A strong acid is injected into the formation and allowed to stand and react, dissolving the formation and enlarging the passageways. Muriat ic acid-is very effective, but it is also dangerous to handle and will corrode pump components, well casings, and sume well screens. Sulfamic acid is more expensive, but it is safer to use because it has no fumes in the dry form and does not irritate the skin. It is also less corrosive to well equipment. Stronger acids can be used with nonmetallic well casings and screens since they are more resistant to corrosion.

E. Innovative Techniques

Development techniques are constantly being refined, and many innovations have arisen through the use of chemical additives. Of spersing ayculs and surfactants hove hocn used alone or with some of the previously mentioned development techniques. 
Dispersing agents cause silt and clay particles (which tend to cling strongly to one another, making them difficult to remove from a well) to repel each other sufficiently so that they can be removed from the well by pumping. The most common dispersing agent is the polyphosphate family of chemicals. The best method of developing wells with polyphosphates is high-velocity jetting. Normal jetting procedures are carried out with a polyphosphate solution instead of water. Merely injecting a polyphosphate solution into the formation adjacent to the screen produces some beneficial results.

A surfactant (wetting agent) is a material which lowers the surface tension of water, thereby making it better able to wet surfaces and to allow water to flow more easily into minute pores and fractures. A major application of wetting agents is in detergents and cleaning compounds used to remove soil. They are inexpensive to use due to their effectiveness in small. concentrations. Surfactants can al so be used to enhance the dispersing efficiency of polyphosphates in removing silt and clay. Acidizing is more effective when a surfactant is used along with the acid because the surfactant enables the acid to permeate all of the pores and fractures, increasing the total area of contact between the acid and material. 
NOTES ON UNITS

The geothermal camumity is an international one, thus all units are given in the International System (SI) with English (Engineering) in parenthesis, i.e. $160^{\circ} \mathrm{C}\left(140^{\circ} \mathrm{F}\right)$. Every attempt was made to use the same number of significant figures in both systems. Thus, for example, $150^{\circ} \mathrm{C}$ would be converted to $30^{\circ} \mathrm{F}$ when used as an exact nuber (three significant figures), and to $300^{\circ} \mathrm{F}$ when used as an approximate number (two significant figures).

The following English and International (SI) relationships and abreviations were used:

English Engineering

1 pound mass (lb)

1 foot-pourd por inch (ft-lh/in)

1 ton (short $=2,000 \mathrm{lb})(\mathrm{tn})$

1 ounce (oz)

1 pound per square foot (psf)

1 pound per square inch (psi)

1 pound per cubic inch ( $p c i)$

1 mile (mi)

1 foot ( $\mathrm{ft}$ )

1 inch (in)

1 gallon (gal)

1 gallon per minute (gpm)

1 ton per hour (T/hr)

1 British themal unit (BTU)

British themal unit per hour (BTU/hr) 1 acre (A)

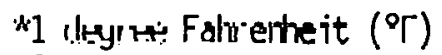

$1^{\circ} \mathrm{F} / \mathrm{mile}$
International System (SI)

$=0.4536$ kilograms $(\mathrm{kg})$

$=0.0054 \mathrm{kilogram-meters} \mathrm{per} \mathrm{cent} \mathrm{imeter}(\mathrm{kg}-\mathrm{m} / \mathrm{cm})$

$=0.9072$ tonne (metric $=1,000 \mathrm{~kg})(\mathrm{t})$

$=28.33$ grams $(g)$

$=4.882$ kilograms per square meter $\left(\mathrm{kg} / \mathrm{m}^{2}\right)$

$=0.0703 \mathrm{kll}$ ograss jer square cent imeter $\left(\mathrm{kg} / \mathrm{cm}^{2}\right)$

$=0.00277 \mathrm{kilograms}$ per cubic cent imeter $\left(\mathrm{kg} / \mathrm{cm}^{3}\right)$

$=1.609$ kilameter $(\mathrm{km})$

$=0.3048$ meters $(\mathrm{m})$

$=2.540$ cent imeters $(\mathrm{cm})$

$=3.785$ liters (1)

$=0.06308$ liter per second $(1 / \mathrm{s})$

$=.252$ kilograms per second $(\mathrm{kg} / \mathrm{s})$

$=1055$ Joules $(\mathrm{J})$

$=1.055$ kilo Joules $(\mathrm{kJ})$

$=0.2930$ watts $(\mathrm{w})$

$=0.4047$ hectares (ha)

$=4047$ square meters ( $\mathrm{m}$ )

$=1.8$ [nogres relrius $\left.\left({ }^{\circ} \mathrm{i}\right)\right]+32^{\circ}$

$=0.345^{\circ} \mathrm{C} / \mathrm{km}$

1 British themal unit per hour per foot per degree Fahrerheit (BTU/hr.Ft. ${ }^{\circ} \mathrm{F}$ )

$=0.0172958$ Joules per second per cent imeter per degree celcius $\left(\mathrm{J} / \mathrm{s}, \mathrm{rm},{ }^{\circ}\right.$.)

$$
\begin{aligned}
& 10^{-6}=\text { micro }(\mathrm{u}) \\
& 10^{-3}=\text { milli }(\mathrm{m}) \\
& 10^{-2}=\text { centi }(\mathrm{c}) \\
& 10^{3}=\text { kilo }(\mathrm{k}) \\
& 10^{6}=\operatorname{mega}(\mathrm{M}) \\
& 10^{9}=\text { giga }(\mathrm{G})
\end{aligned}
$$

*If only a change in temperatıture is required, then $F^{\circ}=1.8 \times\left(\Delta C^{\circ}\right)$ 


\section{REFERENCES}

1. Shalka, M. "Overview of the D.0.E. Direct Use Program for Geothermal Energy" in. Direct Utilization of Geothermal Energy: A Symposium, Geothermal Resources Councils, April, 1978.

2. "Direct Utilization of Geothermal.Energy: A Symposium." Geothermal Resources Council, 1978.

3. "Multipurpose Use of Geothermal Energy." In Proceedings of the International Conference on Geothermal Energy for Industrial, Agricultural, and Commercial-Residential Uses. Geo-Heat Utilization Center, 1974.

4. Smith, R. A.: Geothermal Report Vol. VIII (Sept. 15, 1979), No. 18, p. 4.

5. Milora, S. L., and J. W. Tester: Geothermal Energy as a Source of Electric Power. The MIT press, 1976.

6. DeBerry, D. W., P. F. Ellis, and C. C. Thomas: Materials Selection Guidelines for Geothermal Power Systems. 3rd Ed., Radian Corporation, Report No.. AL0-3904-1, 1979.

7. Austin, A. L., G. H. Higgins, and J. H. Howard: The Total Flow Concept for Recovery of Energy From Geothermal Hot Brine Deposits. Lawrence Livermore Laboratory, 1973.

8. Schaetzle, W. J., and C. E. Brett: Heat Pump-Centered Integrated Community Energy Systems. Univ. of Alabama, 1979.

9. Reistad, G. M.: "Potential for Nonelectric Applications of Geothermal Energy and Their Place in the National Economy." In Proceedings--Second UN Symposium on the Development and Use of Geothermal Resources Vol. 3 (1975), pp. 2155.

10. Jonsson, V. K.: "Geothermal Power Utilization, Present and Future." In Alternate Energy Sources, ed James P. Hartnett, Academic Press, 1976, pp. 290. 
11. Niess, R.C.: "Utilization of Geothermal Energy withan Emphasis on Heat Pumps." In A Symposium of Geothermal Energy and Its Direct Uses in the United States, Geothermal Resources Council, Davis, Cal., April 1979, pp. 73-80.

12. Friend, G. and D. Morri: Kilowatt Counter. Alternative Sources of Energy, Inc., 1975, pp. 14.

13. Lund, John W.: Geothermal Energy Utilization for the Homeowner. Geo-Heat Utilization Center, Dec., 1978.

14. Ellis, A. J., and W. A. J. Mahon: Chemistry and Geothermal Systems. Academic Press, 1977.

15. Wahl, E. F.: Geothermal Energy Utilization. John Wiley \&. Snns, 1977.

16. Arnorsoon, S., et. al.: "Systematic Exploration of the Krisuvik High-Temperat ure Area, Reykjanes Peninsula, Iceland." In Proceedings--Second UN Symposium on the Development and Use of Geothermal Resources Vol. 2, (1975), pp. 853-859.

17. Finnegan, S.A.: Coso Geothermal Corrosion Studies. Naval Weapons Center, China Lake, California, 1977.

19. White, D. E., J. D. Hem, and G. A. Waring: "Chemical Composition of Subsurface Waters." U.S.G.S. Protessionàl Paper 400-F. U. S. Guvernment Frinting Office, 1963.

20. Sigvaldason, G, F.: "Geochemical Methods in Geothermal Exploration." In Geothermal Energy, ed. H. Christopher H. Armstead, UNESCO, 1973, pp. 49-58.

21. Carter, J.P. and S.D. Cramer: "Corrosion Resistance of Some Commerclally Avaflable Melals and Alloys to Cocothermal Brines." In Corrosion Problems in Energy Conversion and Generation, ed Craig S. Fedman, Jr., Electrochemical Suciely, 1974 pp. 240-249.

22. Marshal1, F., and A.J. Hugill: "Corrosion by Low-Pressure Geothermal Steam." Corrosion Vol. 13 (1957), No. 5, pp. 329t-337t.

23. George, P. F., J. A. Manning, Jr., and C. F. Schrieber: Desalination Materials Manual, Dow Chemical Company, 1975. 
24. Water Well Handbook, ed. by K.E. Anderson, 4th Edition, Missouri Geological Survey and Water Resources, Rolla, Missouri, 1977, p. 159.

25. Ground Water and Wells, 4th Printing, The Johnson Div., UOP Inc. 1975, p. 108.

26. Facca, G. "The Structure and Behavior of Geothermal Fluids" In Geothermal Energy, ed. H. Christopher and H. Armstead, UNESC0, 1973, p. 63.

27. Culver, G., and G. M. Reistad: Evaluation and Design of Downhole Heat Exchangers for Direct Applications. Oregon Institute of Technology, 1976.

28. National Water Well Association: A Comprehensive Examination of the Energy Requirements and Costs, With the Environmental and Legal Implications of Expanded Use of Ground Water Geothermal Heat Pumps. In progress.

29. Cummings, R. G., G. E. Morris, J. W. Tester, and R. L. Bivins: "Mining Earth's Heat: Hot Dry Rock Geothermal Energy." Technology Review, Feb, 1979, pp. 59-78.

30. Thomas, H.E., "Ground-water Regions of the United States - Their Storage Facilities," Interior and Insular Affairs Committee Report; 'pp. 14-72, U.S. Congress, Washington, D.C., 1952.

31. Hudson, P.E., and F.W. Nobles: Corrosion Resistant, Nonmetallic Water Well Systems. Radion Corp., 1973.

32. Mruk, S. A.: Thermoplastic Piping, A Report by the ASCE Task Committee on P.lastic Pipe. Presented at the ASCE Annual Convention, San Francisco, Cal ifornia, October $17-21,1977$.

33. Kurt, Carl E.: "Collapse Pressure of Thermoplastic Water Well Casing." Ground Water Vol. 17 (Nov.-Der., 1979), No. 6, pp. 550-555.

34. National Water Well Association and the Plastic Pipe Institute: Manual of Installation Practices for Thermoplastic Water Well Casing, publication date pending approval by ASTM F.480 committee.

35. Lammers, J. R.: Private Communication, Burgess Well Company, Iric. Minden, Nebraska, 1979. 
36. Campbell, M.D., and J. H. Lehr: Water Well Technology. McGraw Hill, 1977.

37. Angles, P. J.: "Fiberglass Casing Used in Corrosive Geothermal Wells." 0il and Gas Journal Vol. 77, No. 42, pp. 131-132, 0ct. 15, 1979.

38. American Society for Testing and Materials, Standard Specification for Thermoplastic Water Well Casing Pipe and Coupling made in Standard Dimension Ratios (5DR) ANSI/ASTM F480-76.

39. Moss, R., Jr., "Design of Casing and Screens for Water Production and Injection Wells." A.P.I. Pacific Coast District Biennial Symposium, Treatment and Control of Injection Wells, Annaheim, Cal., Dec., 1964.

40. Smith, D.K.: Cementing. Society of Fetroleumi Enyineers --AIME, New York, 1976, p. 130.

41. Zeldin, A., L.E. Kukacka, and N. Carciello: "Polymer Systems in Geothermal Appl ications." Journal of Applied Polymer Science Vol. 23 (1979), pp. 3179-3191.

42. Whitbeck, J. F.: Private Communication. EG\&G Idaho, Inc. Idàho Falls, Idaho, 1979.

43. Industrial Thermoplastic Piping Systems: A Manual for Consulting and Plant Engineers, eds. J. J. Blunen-Kranz and R. R. Schalje, R \& G Sloane Manufacturing Co., Inc., 1978, pp. 24.

44. Schrock, B. J.: Thermosetting Resin Pipe. ASCE Reprint. 3088 , Uct., 1977, pp. 20 .

45. Marshall, F. and W.R. Braithwaite: "Corrosion Control in Geothermal Systems." In Geothermal Energy, ed

H. Christopher H. Armstead, UNESC0, 1973; $\mathrm{p} .157-160$.

46. Costello, R.M., T. Amerlaan, S.V. Cabibbo, and L.E. Kukacka: Economic Assessment of Using Non-metallic Materials in the Direct Utifization of Geothermal Energy. Burns and Roe Industrial Service Corp. and Bruokhaven National Laboratory, 1979.

47. ASTM Task Group on Geothermal Seals, "Proceedings of Technical Seminar." Conf. 7806141, 1978. 
48. Lorensen, L.E., C.M. Walkup, and C.0. Pruneda:

Polymeric and Composite Materials For Use In Systems

Utilizing Hot, Flowing Geothermal Brine III. Lawrence Livermore Laboratory, June, 1979.

49. Mogy, J.L.: "Practical Corrosion and Incrustation

Guidelines for Water Wells." Ground Water Vol. 10, No. 2, March-April, 1973, pp. 9.

50. Cloud, P.J., and J.E. Theberge: "Thermal and "Environmental Resistance of Glass-Reinforced

Themoplastics, Part II." Machine Design Sept. 30, 1971.

51. Johnson, R.C. Jr., C.E. Kurt, and G.F. Dunham, Jr., "Well Grouting and Casing Temperature Increases", Gound Water, Vol. 18, No. 1, Jan.-Feb., 1980.

U.S. GOVERNMENT PRINTING OFFICE: $614-090-\$ 20^{\circ}$ 